\title{
Profits and Balance Sheet Developments at U.S. Commercial Banks in 1999
}

\begin{abstract}
William F. Bassett and Egon Zakrajšek, of the Board's Division of Monetary Affairs, prepared this article. Thomas C. Allard assisted in developing the database used in this article and was responsible for maintaining it. James E. Cypert, Jr., provided research assistance.
\end{abstract}

The U.S. commercial banking industry posted record earnings in 1999. The industry's return on assets and return on equity both rose above the already high level of recent years (chart 1). ${ }^{1}$ Profitability was concentrated at large banks-particularly among the 100 largest - and was driven upward by a surge in noninterest income and a significant slowdown in the growth of noninterest expense. Other sources of improved profitability were a stabilization of net interest income, which had been weakening in recent years, and lower loan loss provisioning permitted by generally good asset quality. On the negative side, 641 banks lost money in 1999; these institutions accounted for 7.4 percent of all domestic commercial banks in operation last year but for only about 1.5 percent of the industry's assets.

1. Except where otherwise indicated, data in this article are from the quarterly Reports of Condition and Income (Call Reports) for insured domestic commercial banks and nondeposit trust companies (hereafter, banks). The data consolidate information from foreign and domestic offices and have been adjusted to take account of mergers. For additional information on the adjustments to the data, see the appendix in William B. English and William R. Nelson, "Profits and Balance Sheet Developments at U.S. Commercial Banks in 1997," Federal Reserve Bulletin, vol. 84 (June 1997), p. 408.

Size categories, based on assets at the start of each quarter, are as follows: the 10 largest banks, large banks (those ranked 11 through 100), medium-sized banks (those ranked 101 through 1,000), and small banks (those not among the largest 1,000 banks). At the start of the fourth quarter of 1999, the approximate asset sizes of the banks in those groups were as follows: the 10 largest banks, more than $\$ 74$ billion; large banks, $\$ 6.3$ billion to $\$ 74$ billion; mediumsized banks, $\$ 326$ million to $\$ 6.2$ billion; small banks, less than $\$ 326$ million.

Many of the data series reported here begin in 1985 because the Call Reports were significantly revised at the start of that year. Data for 1984 and earlier years are taken from Federal Deposit Insurance Corporation, Statistics on Banking (FDIC, 1999). The data reported here are also available on the Internet, at www.fdic.gov/bank/ statistical/statistics/index.html/

Data shown in this article may not match data published in earlier years because of revisions and corrections. In the tables, components may not sum to totals because of rounding.
1. Measures of commercial bank profitability, 1975-99

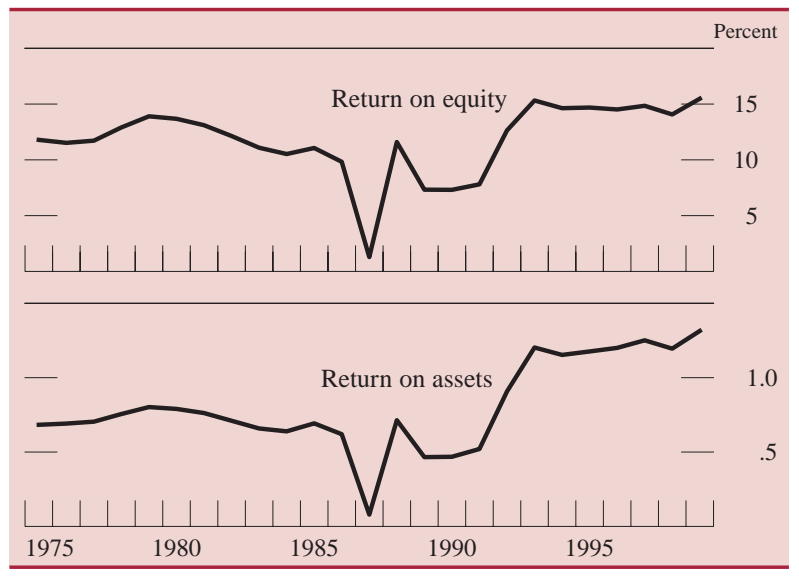

Components of bank credit and bank deposit liabilities that had been boosted by the financial turmoil of 1998 declined early last year as financial markets calmed. Nonetheless, demand for household and business credit remained strong because of the rapid pace of economic activity. At the end of 1998, long-term private interest rates started to trend up, and from June to November 1999 the Federal Reserve increased the intended level of the federal funds rate three times in 25 basis point increments (chart 2).

\section{Selected interest rates, 1997-99}

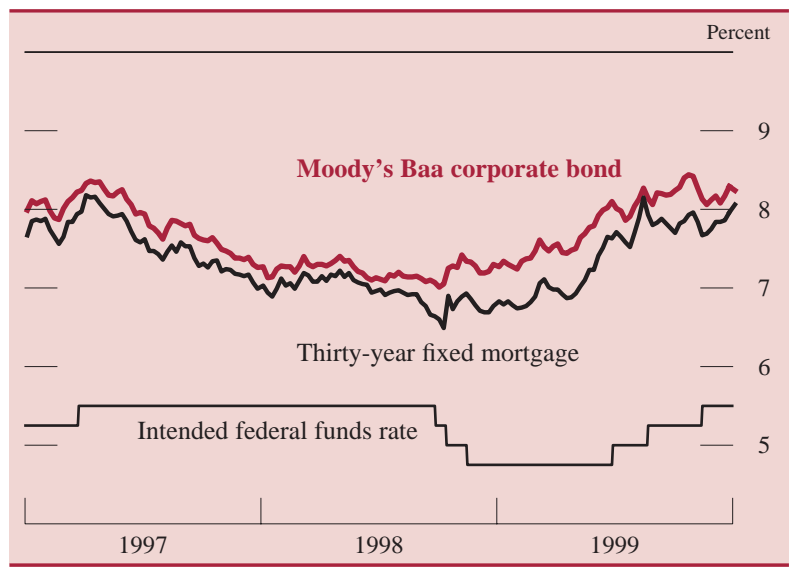

SOURCE. For intended federal funds rate, Federal Reserve board; for bond and mortgage rates, Federal Reserve Board, Statistical Release H.15, "Selected Interest Rates." 
3. Number of commercial banks and share of assets at the largest 100 banks, 1970-99

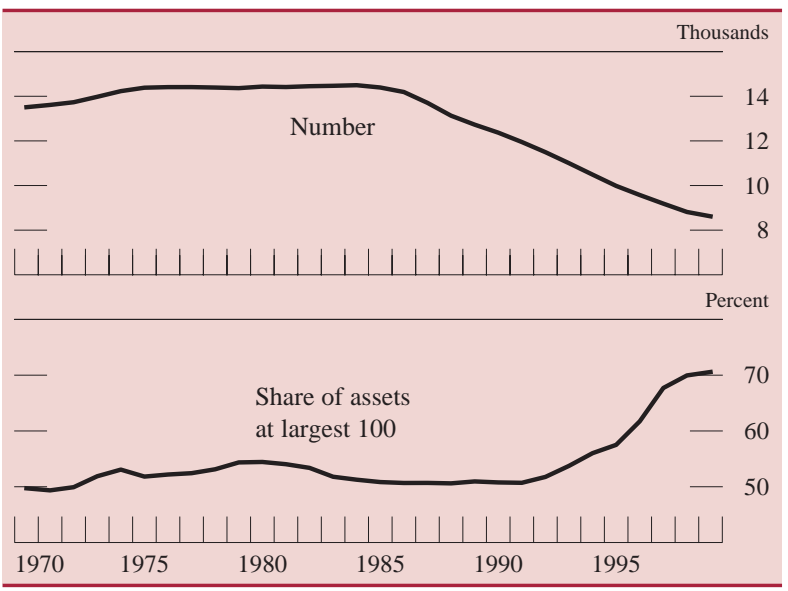

Consolidation within the banking industry slowed significantly in 1999. The net reduction in the number of banks, 195, was only about half the decline in each of the preceding two years. Among the 450 banks that ceased operations last year, 8 failed, and the remaining 442 merged with other banks, were purchased outright, or otherwise changed their charters. Meanwhile, 255 new banks were createdthe most in one year since 1987. At the end of 1999, 8,620 banks were in operation, down from 12,728 a decade ago (chart 3 ). The share of industry assets held by the 100 largest banks moved up just $1 / 2$ percentage point, to 70 percent, after having jumped an average of 4 percentage points per year between 1995 and 1998.

Consolidation slowed even more dramatically among bank holding companies (BHCs) in 1999, perhaps in part because of the poor performance of

1. Annual rates of growth of balance sheet items, 1990-99 Percent

\begin{tabular}{|c|c|c|c|c|c|c|c|c|c|c|c|}
\hline Item & 1990 & 1991 & 1992 & 1993 & 1994 & 1995 & 1996 & 1997 & 1998 & 1999 & $\begin{array}{c}\text { Mемо: } \\
\text { Dec. } \\
1999 \\
\text { (billions } \\
\text { of } \\
\text { dollars) }\end{array}$ \\
\hline Assets $\ldots \ldots \ldots \ldots \ldots$ & 2.64 & 1.33 & 2.19 & 5.68 & 8.06 & 7.55 & 6.09 & 9.24 & 8.22 & 5.44 & 5.673 \\
\hline Interest-earning assets & 2.23 & 1.98 & 2.53 & 6.56 & $\begin{array}{l}0.00 \\
5.77\end{array}$ & 7.69 & $\begin{array}{l}0.09 \\
5.67\end{array}$ & $\begin{array}{l}9.24 \\
8.88\end{array}$ & $\begin{array}{l}.22 \\
8.18\end{array}$ & 5.99 & 4,908 \\
\hline Loans and leases (net) ......... & 2.37 & -2.65 & -1.04 & 6.05 & 9.83 & 10.53 & 8.12 & $\begin{array}{l}0.00 \\
8.38\end{array}$ & $\begin{array}{l}0.10 \\
8.90\end{array}$ & 8.01 & 3,394 \\
\hline Commercial and industrial & -.67 & -9.10 & -4.10 & .52 & 9.33 & 12.26 & 7.24 & 12.02 & 12.96 & 8.07 & 965 \\
\hline Real estate $\ldots \ldots \ldots \ldots \ldots$ & 8.79 & 2.73 & 1.94 & 6.13 & 7.90 & 8.33 & 5.44 & 9.30 & 7.98 & 12.17 & 1,497 \\
\hline $\begin{array}{l}\text { Booked in domestic offices } \\
\text { One- to four-family }\end{array}$ & 8.55 & 2.90 & 2.57 & 6.17 & 7.64 & 8.48 & 5.50 & 9.53 & 7.96 & 12.31 & 1,465 \\
\hline residential ......... & 14.00 & 7.76 & 7.53 & 11.08 & 10.09 & 10.06 & 4.65 & 9.67 & 6.34 & 9.65 & 831 \\
\hline Other $\ldots \ldots \ldots \ldots \ldots$ & 3.62 & -1.93 & -2.86 & .22 & 4.35 & 6.25 & 6.75 & 9.33 & 10.28 & 16.01 & 633 \\
\hline Booked in foreign offices & 16.64 & -2.35 & -17.80 & 4.67 & 18.35 & 2.81 & 3.18 & .34 & 8.79 & 6.28 & 33 \\
\hline Consumer .................. & .38 & -2.55 & -1.66 & 9.06 & 16.01 & 9.50 & 4.90 & -2.18 & 1.00 & -1.48 & 541 \\
\hline Other loans and leases & -5.68 & -4.91 & -4.24 & 9.97 & 5.29 & 14.23 & 22.28 & 13.73 & 14.02 & 6.35 & 451 \\
\hline $\begin{array}{c}\text { Loan-loss reserves and } \\
\text { unearned income }\end{array}$ & 35 & -3.78 & -4.85 & -582 & -2.22 & 25 & -06 & -49 & 3.30 & 250 & 61 \\
\hline Securities ................ & 8.46 & 16.23 & $\begin{array}{l}-4.83 \\
12.29\end{array}$ & 12.26 & -2.61 & .57 & .84 & 8.86 & $\begin{array}{l}3.30 \\
8.36\end{array}$ & 5.10 & 1,146 \\
\hline Investment account & 8.19 & 14.42 & 11.44 & 8.11 & -1.73 & -1.58 & -1.12 & 8.68 & 12.05 & 6.64 & 1,029 \\
\hline $\begin{array}{l}\text { U.S. Treasury } \ldots . . . \\
\text { US government age }\end{array}$ & 3.50 & 32.01 & 23.95 & 7.24 & -8.46 & -19.21 & -14.30 & -8.85 & -25.17 & -1.89 & 111 \\
\hline $\begin{array}{l}\text { U.S. government agenc } \\
\text { corporation obliga }\end{array}$ & 24.02 & 15.88 & 12.77 & 9.62 & .87 & 6.43 & 3.61 & 14.20 & 16.98 & 1.82 & 595 \\
\hline Other ......... & -6.70 & -2.56 & -5.20 & 6.09 & 2.49 & 4.20 & 1.82 & 11.21 & 26.97 & 20.78 & 323 \\
\hline Trading account & 11.87 & 38.88 & 21.01 & 51.84 & -9.43 & 18.51 & 14.44 & 9.97 & -13.52 & $\begin{array}{l}-6.69 \\
-109\end{array}$ & 117 \\
\hline Other $\ldots \ldots \ldots \ldots$ & -11.70 & 2.82 & 1.57 & -7.90 & 3.25 & 7.64 & -.90 & 12.81 & 2.35 & -7.57 & 369 \\
\hline Non-interest-earning assets & 5.51 & -3.10 & -.32 & -.86 & 25.65 & 6.61 & 8.87 & 11.48 & 8.48 & 2.08 & 765 \\
\hline Liabilities ..... & 2.37 & 1.01 & 1.35 & 5.12 & 8.31 & 7.17 & 5.95 & 9.13 & 8.09 & 5.58 & 5,201 \\
\hline Core deposits ............. & 7.58 & 5.25 & 5.09 & 1.49 & $\begin{array}{l}0.01 \\
-.17\end{array}$ & 3.97 & & & & .20 & 2,675 \\
\hline Transaction deposits .............. & 2.43 & 3.38 & 14.62 & 5.47 & -.33 & -3.09 & -3.45 & -4.54 & -1.41 & -8.98 & 679 \\
\hline Savings and small time deposits & 10.51 & 6.24 & .18 & -.85 & -.08 & 8.37 & 8.34 & 9.04 & 10.73 & 3.76 & 1,996 \\
\hline $\begin{array}{l}\text { Managed liabilities } 1 \\
\text { Deposits booked in foreign }\end{array}$ & -6.15 & -6.19 & -6.07 & 12.30 & 17.57 & 10.44 & 9.65 & 13.84 & 9.60 & 15.49 & 2,177 \\
\hline $\begin{array}{l}\text { Deposits booked in foreign } \\
\text { offices ................ }\end{array}$ & -5.88 & 3.81 & -5.85 & 15.06 & 30.89 & 5.13 & 4.27 & 11.13 & 8.71 & 14.60 & 655 \\
\hline Large time $\ldots \ldots \ldots \ldots \ldots \ldots$ & -5.68 & -19.73 & -26.20 & -9.21 & 8.72 & 19.61 & 21.16 & 20.15 & 9.10 & 14.17 & 472 \\
\hline $\begin{array}{l}\text { Subordinated notes and } \\
\text { debentures .......... }\end{array}$ & 20.99 & 4.69 & 34.90 & 10.82 & 9.23 & 6.61 & 17.74 & 21.05 & 17.00 & 5.07 & 76 \\
\hline Other managed liabilities & -8.06 & -1.39 & 6.94 & 22.18 & 12.91 & 11.24 & 8.21 & 12.23 & 9.87 & 17.68 & 974 \\
\hline Other $\ldots \ldots \ldots \ldots \ldots \ldots$ & 4.43 & -4.18 & -1.02 & 15.30 & 79.17 & 20.46 & 2.60 & 23.79 & 8.15 & -6.06 & 349 \\
\hline Equity capital & 6.64 & 5.98 & 13.75 & 12.58 & 5.24 & 12.00 & 7.72 & 10.46 & 9.61 & 3.95 & 472 \\
\hline Мемо & & & & & & & & & & & \\
\hline Commercial real estate loans ${ }^{2}$ & 3.62 & -2.58 & -4.03 & -.60 & 4.00 & 6.35 & 7.66 & 10.13 & 11.36 & 15.37 & 639 \\
\hline Mortgage-backed securities . & 34.39 & 19.27 & 10.37 & 9.66 & -3.12 & .67 & 2.03 & 14.18 & 22.09 & -3.34 & 449 \\
\hline
\end{tabular}

Note. Data are from year-end to year-end.

2. Measured as the sum of construction and land development loans secured

1. Measured as the sum of deposits in foreign offices, large time deposits in domestic offices, federal funds purchased and securities sold under repurchase agreements, demand notes issued to the U.S. Treasury, subordinated notes and debentures, and other borrowed money. by real estate; real estate loans secured by nonfarm nonresidential properties; real estate loans secured by multifamily residential properties; and loans to finance commercial real estate, construction, and land development activities not secured by real estate. 
their equity prices. The number of mergers between BHCs last year, 211, was the lowest since 1994; and the number of BHCs declined a net of only 27 , to 5,953 , by year's end. The percentage of BHC assets controlled by the 50 largest organizations remained steady at about 76 percent.

\section{BALANCE SHEET DEVELOPMENTS}

The growth of total bank assets slowed from 8.2 percent in 1998 to 5.4 percent in 1999 (table 1). The deceleration was most evident in securities holdings, in large part because, for a significant share of these assets, price declines associated with a rise in interest rates must be marked to market. In addition, core deposit inflows virtually stopped, leading banks to fund asset growth primarily through the issuance of relatively expensive managed liabilities.

Meanwhile, loans expanded a brisk 8 percent, about the same pace as in 1998, when bank lending was given a considerable boost by the Russian default

4. Financing gap and net equity retirement at nonfarm nonfinancial corporations, 1990-99

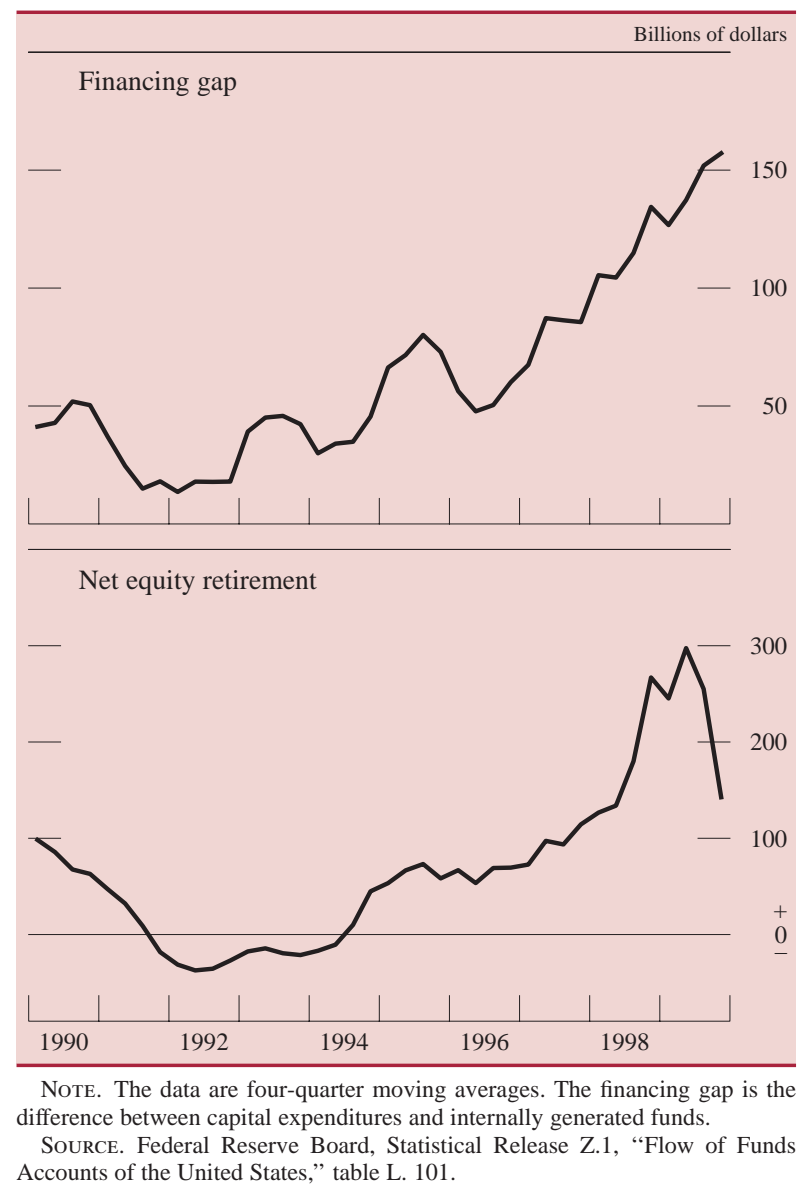

in August of that year. Within loan categories, the growth of commercial and industrial loans moderated but remained strong, and real estate loans grew vigorously. Consumer loans originated by banks rose moderately last year. ${ }^{2}$

\section{Loans to Businesses}

Growth of loans to commercial and industrial (C\&I) enterprises expanded a strong 8.1 percent in 1999 , although the pace was down somewhat from the average of the previous two years. C\&I lending last year was supported by a large rise in business outlays on capital goods that exceeded the increase in cash flow (chart 4). Cash-financed mergers and acquisi-

2. In contrast, consumer loans on banks' books fell slightly because securitizations (selling loans as backing for securities, a process that takes the loans off the banks' balance sheets) rose faster than originations.

5. C\&I loan standards and terms of selected commercial banks, by size of borrower, 1997-2000:Q1

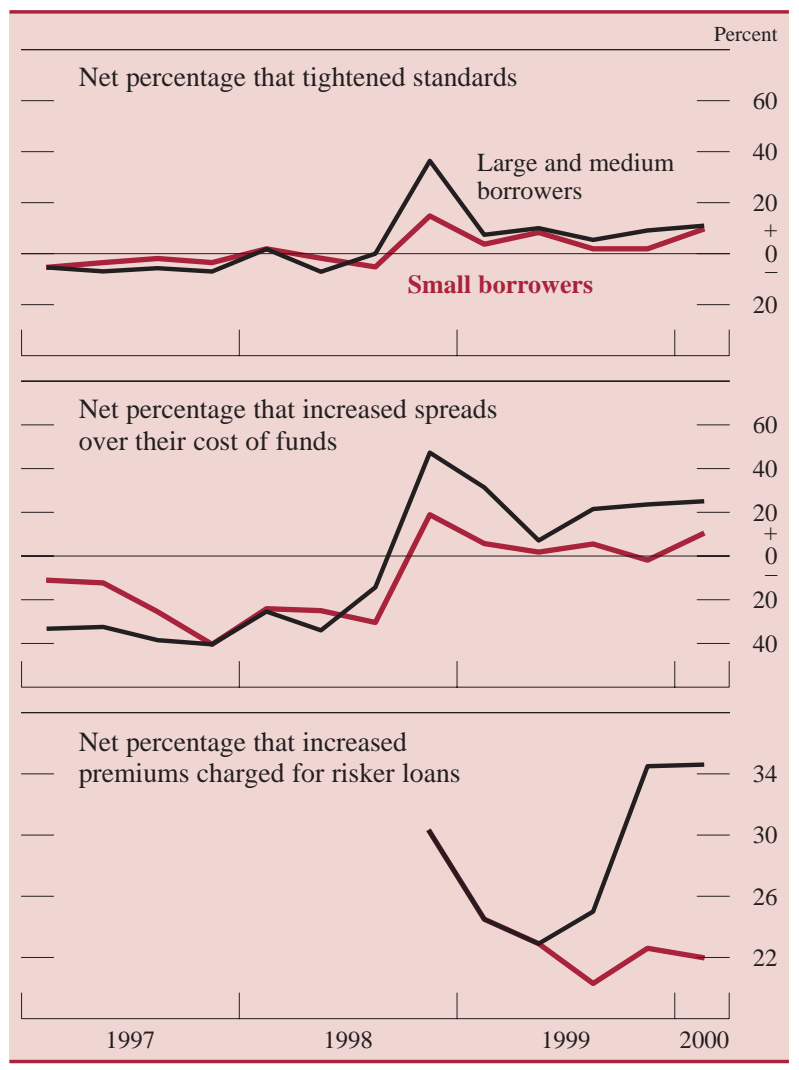

Note. Net percentage is the percentage of banks reporting a tightening of standards or an increase in spreads or premiums less the percentage reporting an easing or decrease. The definition for firm size suggested for, and generally used by, survey respondents is that medium-sized firms are those with sales of between $\$ 50$ million and $\$ 250$ million.

Data was collected on risk premiums beginning in 1998:Q4.

Source. Federal Reserve Board, "Senior Loan Officer Opinion Survey on Bank Lending Practices." 
tions, however, boosted overall financing needs by less than the previous year as the pace of net equity retirement slowed. Cash purchases of equity are frequently financed with bank loans, at least initially, and changes in merger and acquisition financing needs are typically cited as the main reason for changes in loan demand by respondents to the Federal Reserve's quarterly Senior Loan Officer Opinion Survey on Bank Lending Practices (BLPS). ${ }^{3}$

3. The survey sample is selected from among the largest insured domestic commercial banks in each Federal Reserve District and from among the largest foreign-related banking institutions in those Federal Reserve Districts where such institutions are common. As of December 31, 1999, the 57 domestic banks covered in the May 2000 survey accounted for nearly half of the $\$ 4.95$ trillion in assets held by all domestic banks; and the 21 foreign-related institutions accounted for nearly 30 percent of the $\$ 806$ billion in assets held by all such institutions in the United States. The survey is available at www.federalreserve.gov/boarddocs/SnLoanSurvey/

6. Spread between the average C\&I loan rate and the intended federal funds rate, for all C\&I loans, 1986-2000:Q1, and by risk rating of loan, 1997:Q2-2000:Q1

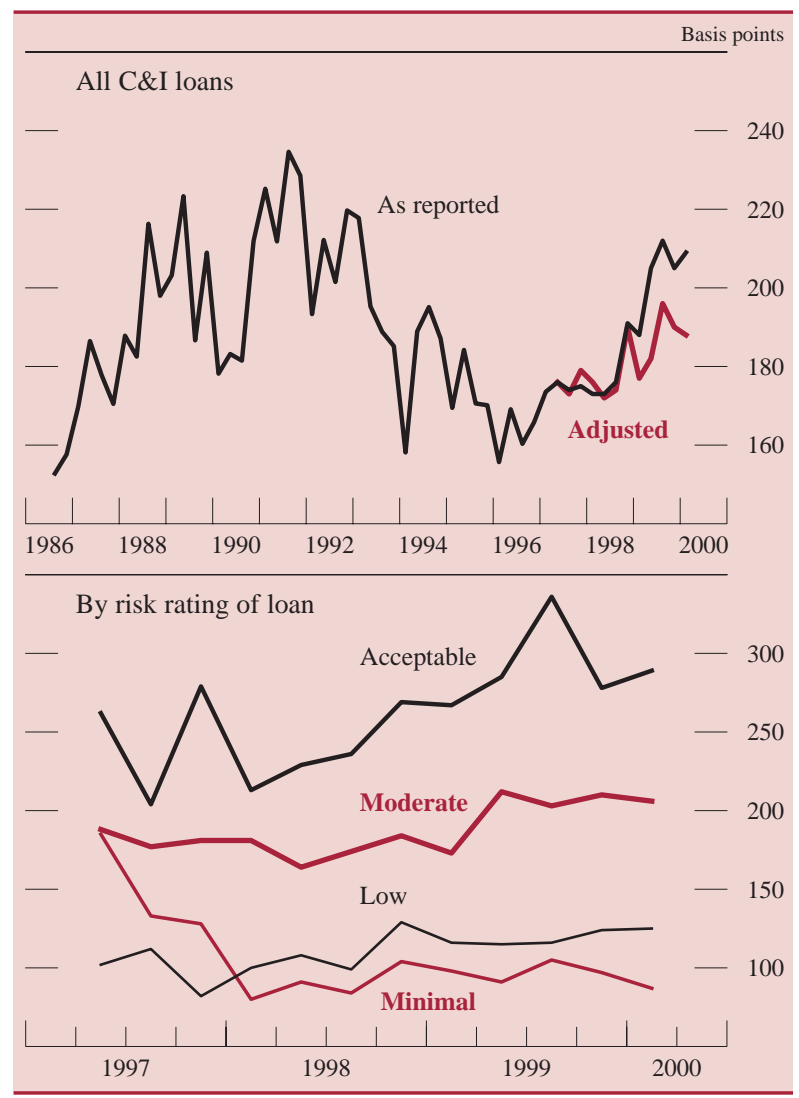

Note. The data are weighted by loan volume. "Adjusted" data are adjusted for compositional effects such as changes in the underlying distribution of maturity, size, and riskiness of loans over time. Data in bottom panel are as reported.

Source. Federal Reserve Board, Statistical Release E.2, "Survey of Terms of Business Lending."
In the wake of the Russian default, a large fraction of respondents to the BLPS reported tightening their standards and terms for C\&I loans during the fourth quarter of 1998 (chart 5). As financial markets calmed during 1999, however, there was no indication that banks' standards or terms became any less stringent. In fact, on net, small fractions of BLPS respondents continued to report tightening standards and charging higher spreads on C\&I loans. As the year unfolded, increasing fractions of banks reported charging higher premiums on riskier loans to large and medium-sized businesses, possibly because of admonitions by banking regulatory agencies for vigilance in the area of loan quality. ${ }^{4}$

Information from the Federal Reserve's quarterly Survey of Terms of Business Lending (STBL) was consistent with the information from the BLPS, suggesting that banks had tightened lending standards and terms over the past year. ${ }^{5}$ In the STBL, the share of loan originations that was secured by collateral hovered at levels near the top of the historical range, as did the share of loan originations made under commitment. In addition, the dollar volume of loan originations rated as being of minimal or low risk increased from 29 percent of total originations in 1998 to 33 percent in $1999 .{ }^{6}$

STBL data also corroborate evidence from the BLPS that banks charged higher spreads on business loans in general and on riskier loans in particular. The average spread of loan rates over the intended federal funds rate on new C\&I loans (adjusted for changes in the composition of loan originations) increased dramatically during the fourth quarter of 1998 and remained close to that elevated level throughout 1999 (chart 6). Indeed, the average spread on relatively risky loans made last year rose well above the levels established during the fourth quarter of 1998,

4. Board of Governors of the Federal Reserve System, "Recent Trends in Bank Lending Standards for Commercial Loans," Supervision and Regulation Letters SR 99-23 (SUP), September 28, 1999, available at www.federalreserve.gov/boarddocs/srletters/1999/ sr9923.htm/

5. The STBL data are based on a representative sample of up to 348 insured domestic commercial banks and up to 50 foreign-related banking institutions. The sample data are used to estimate the terms of loans extended during the survey period at all domestic banks and at all foreign-related institutions. The data are available at www.federalreserve.gov/releases/E2/

6. Loans in the STBL receive risk ratings ranging from 1 to 5 , which correspond to minimal risk, low risk, moderate risk, acceptable risk, and classified, respectively. For more information on loan rating categories in the STBL see, Thomas F. Brady, William B. English, and William R. Nelson, "Recent Changes to the Federal Reserve's Survey of Terms of Business Lending." Federal Reserve Bulletin, vol. 84 (August 1998), pp. 604-15. 
7. Bank loans as a share of total nonmortgage credit market debt, nonfinancial businesses, 1980-99

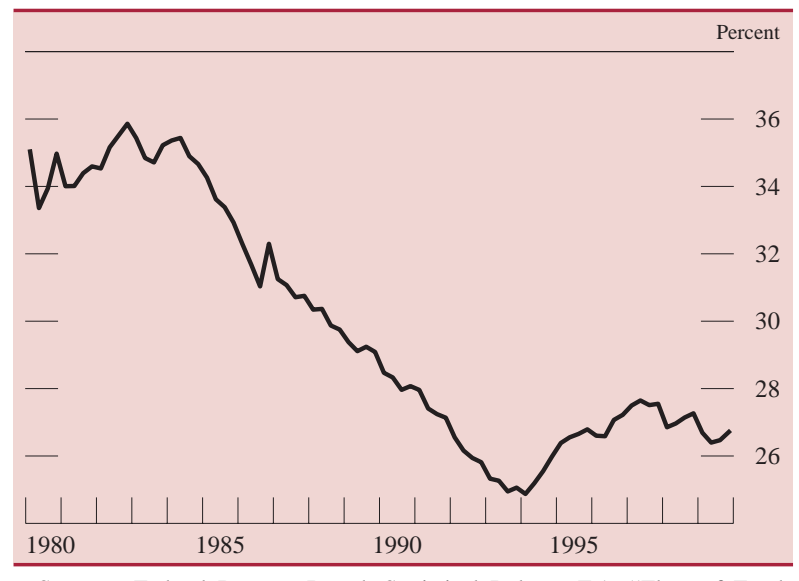

Source. Federal Reserve Board, Statistical Release Z.1, "Flow of Funds Accounts of the United States," table L. 101.

accounting for much of the upward trend in the overall average loan spread. ${ }^{7}$

Partly because of these developments, bank loans as a share of nonmortgage credit market debt owed by the nonfinancial business sector declined last year, as firms that borrowed met somewhat more of their funding needs by issuing commercial paper and bonds (chart 7). However, in the year's final quarter, the share of bank loans rose, particularly for larger banks, perhaps because of concerns about the risk of computer-related business disruptions during the century date change. Inventory growth picked up in that quarter, firms appeared to build up liquid assets for precautionary reasons, and bond issuance was curtailed, all adding to demand for intermediated debt. Nonetheless, BLPS respondents reported that concerns about the transition to the year 2000 had only a limited influence on bank lending (see box "Business Lending around the Century Date Change").

In jumping more than 15 percent, commercial real estate loans last year registered their largest increase since 1987, suggesting that rising interest rates had a limited effect on demand in this market. The rapid growth was also in spite of BLPS respondents' indications that they had tightened standards for commercial real estate lending in response to the financial market distress in the fourth quarter of 1998 (chart 8). The quickened pace was evident among banks of all

7. Between 1998 and 1999, the four-quarter uncentered moving average spread over the intended federal funds rate-weighted by volume-increased only 8 basis points on 1-rated (minimal-risk) loans and 9 basis points on 2-rated (low-risk) loans; in contrast, the corresponding spreads for 3-rated and 4-rated loans increased 24 basis points and 55 basis points respectively.
8. Net percentage of selected commercial banks that tightened standards for commercial real estate loans, 1990-2000:Q1

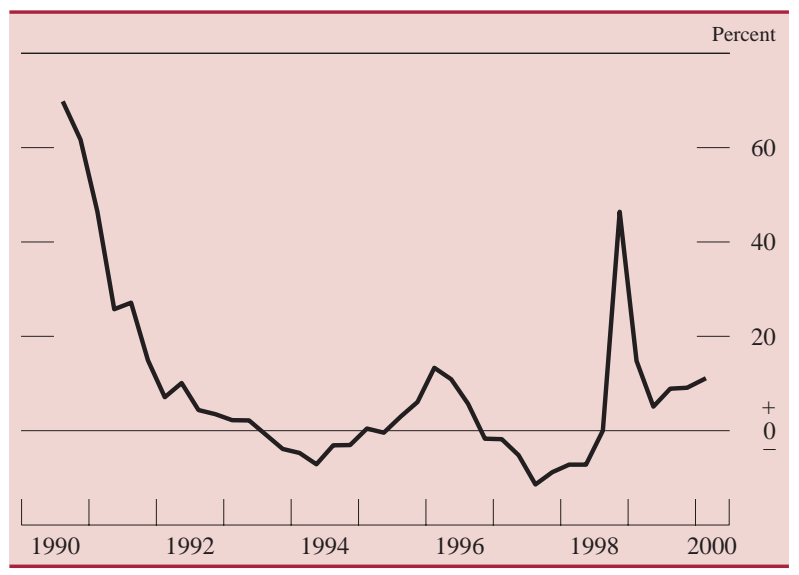

NotE. Net percentage is the percentage of banks that reported a tightening of standards less the percentage that reported an easing.

Source. Federal Reserve Board, "Senior Loan Officer Opinion Survey on Bank Lending Practices."

sizes and in all categories of commercial real estate lending-multifamily housing, construction and land development, and nonfarm, nonresidential real estate. Construction and land development loans advanced most rapidly, 27 percent, while multifamily housing grew nearly 23 percent last year, a sharp acceleration from the 5 percent pace in 1998.

In addition to the strong economy, two other factors contributed to boosting commercial real estate loans. Real estate investment trusts (REITs), which overall suffered a decline in their stock prices of nearly 20 percent in 1999, were much less active in acquiring and developing properties. Private

9. Spread between the yield on commercial-mortgagebacked securities and the rate on ten-year Treasury bonds, 1997-99

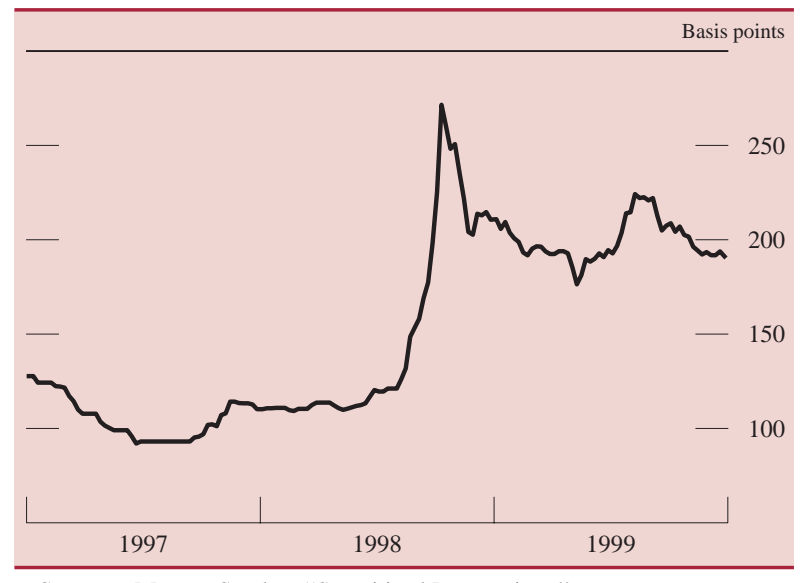

Source. Morgan Stanley, "Securitized Perspectives." 


\section{Business Lending around the Century Date Change}

Over the past two years, the Federal Reserve Board's quarterly Senior Loan Officer Opinion Survey on Bank Lending Practices (BLPS) has asked banks to report on their management of risks related to potential Year 2000 (Y2K) problems and about the supply of, and the demand for, business credit extending over the century date change. According to the May 1999 survey, a large majority of banks had evaluated more than 90 percent of their material business customers for $\mathrm{Y} 2 \mathrm{~K}$ preparedness. ${ }^{1}$ By August, almost all banks had reached this level, and more than 95 percent of the customers that they had evaluated were making satisfactory progress.

About 80 percent of BLPS respondents consistently reported that $\mathrm{Y} 2 \mathrm{~K}$ issues had no effect on either the standards or the terms being applied to renewals of existing lines of credit, even if their new maturity date extended into 2000. In addition, almost all banks reported that, for existing customers, they were willing to extend lines of credit specifically designed for addressing Y2K concerns. However, only one-third of the respondents were willing to extend such lines to new customers. Moreover, many banks applied somewhat tighter standards and terms to Y2K contingency lines of credit than to otherwise similar lines for similar borrowers, and demand for such lines was not widespread.

The Federal Reserve actively attempted to assuage fears about the cost of funds extending over year-end. A "century date change special liquidity facility" (SLF) made Federal Reserve credit available to depository institutions in sound financial condition without the usual administrative constraints on discount window borrowing. The SLF was available from October 1, 1999, to April 7, 2000, and offered loans at a premium of 150 basis points over the Federal Open Market Committee's intended federal funds rate.

1. A material business customer is one that represents a material risk as indicated, for example, by the size of the overall relationship with the customer, the customer's risk rating, the complexity of the customer's operating and information technology systems, and the degree of the customer's reliance on these systems.
Weekly data on bank credit revealed strong growth in both C\&I loans and security loans during November and early December as banks' balance sheets expanded rapidly in the fourth quarter of 1999. In the November 1999 BLPS, several large banks reported increased demand from C\&I firms seeking to avoid high interest rates in the commercial paper market. In the January 2000 BLPS, however, only a few respondents suggested that the rise in demand for C\&I loans in the fourth quarter of 1999 was, even in part, specifically due to concerns related to the century date change. For security loans, the BLPS respondents indicated that brokers and dealers had experienced heavy funding needs and, in fact, turned to banks when the cost of commercial paper with maturities extending over yearend rose markedly and other institutional lenders pulled back (chart).

Spread between the yield on three-month nonfinancial commercial paper and the intended funds rate, 1999-2000:Q1

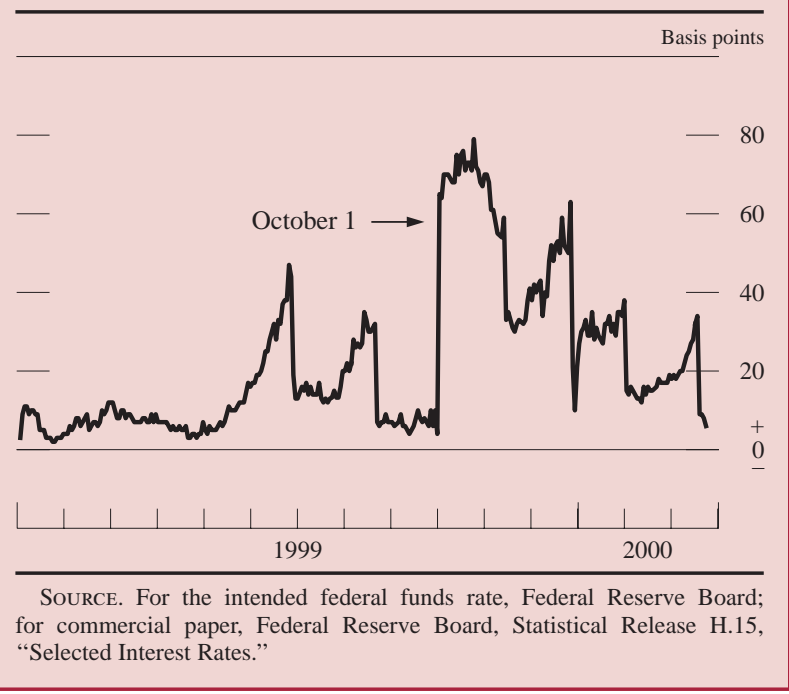

generally rely on CMBS financing rather than carrying loans on their balance sheets.

\section{Loans to Households}

Banks were important suppliers of consumer credit again last year. The small slippage in the stock of consumer loans held by banks in 1999 reflected the high proportion of these loans that were securitized (see text note 2), a proportion that increased again in 1999 (chart 10). Correspondingly, the share of consumer loans in banks' loan portfolios fell to a new low of about 16 percent. Counting securitized loans, 


\section{Business Lending around the Century Date Change-Continued}

\section{Evidence from the $S T B L$}

A statistical examination of the Federal Reserve's quarterly Survey of Terms of Business Lending (STBL) suggests that loans made under commitment and maturing in the first three months of 2000 were only minimally more expensive because of their maturity dates-about 6 basis points. ${ }^{2}$ This result is consistent with the information from the BLPS that indicated that most banks were not increasing the cost of outstanding lines of credit for $\mathrm{Y} 2 \mathrm{~K}$ lending. However, even loans that were not made under commitment and that matured in the first quarter carried only 22 extra basis points on their spreads. Banks may have been able to charge relatively low risk premiums at that time because of the effectiveness of their preceding efforts to monitor their customers' Y2K preparedness.

\section{Aftermath}

In the end, the century date change passed without any major disruptions to financial markets and few reports of

2. Using data from the STBL, we examined the effect that various loan characteristics (such as risk rating, maturity, commitment status, and so on) may have had on the spread of fixed-rate loans over the intended federal funds rate. To estimate the effect of Y2K jitters on this spread, we used an indicator variable for loans maturing in the first quarter of 2000 plus a variable representing the interaction of those loans with commitment status. Numerous other versions of this regression equation yielded qualitatively similar results (results available upon request).
Y2K-related difficulties elsewhere. The spread between the rate on three-month commercial paper and the intended federal funds rate fell consistently from its October peak through the early part of 2000. Evidently in response, security loans ran off through the end of February, reversing their earlier rise. Banks also experienced some runoff of C\&I loans during the last two weeks of December and first two weeks of January. In the January BLPS, banks mentioned buildups of inventories and liquidity to explain strong demand for C\&I loans in the final months of 1999, and it was possible that some of the strength in C\&I lending was for Y2K-related reasons that were not evident to respondents. However, few domestic banks reported that they extended more than a negligible amount of credit under $\mathrm{Y} 2 \mathrm{~K}$ contingency lines.

Most banks reported no unusual funding pressures around year-end. Sixty percent reported that neither credit demands nor deposit flows were materially affected by Y2K-related concerns. In addition, the increase in the demand for currency near year-end was smaller than banks expected, and they were thus left with large amounts of vault cash (which increased \$27 billion in the fourth quarter of 1999). Because vault cash earns no return, this accumulation likely had a small adverse effect on bank profitability during the final quarter of last year. however, consumer loans originated by banks grew an estimated 4.7 percent in $1999 .^{8}$

Banks were willing suppliers of consumer credit, according to BLPS respondents, who also indicated that demand for consumer loans became moderately stronger, on net, throughout the year. However, the survey also suggested that banks, on net, continued to tighten standards and charge moderately higher spreads on credit card loans, which may have contributed to the fall in such loans at banks (chart 11).

Real estate loans for one- to four-family homes increased 9.7 percent at banks, up from 6.3 percent in 1998. In part, the acceleration reflected an exceptionally strong housing market, with new and existing home sales reaching record levels early in the year despite the rise in mortgage rates that began at the end of 1998. In addition, rising interest rates drove up the share of mortgage lenders' originations

8. The growth at banks, however, lagged behind the 7.3 percent growth of consumer credit originated by all lenders. The notable overall strength in auto lending and leasing - activities in which banks are not major players-may have contributed to their lagging performance. that were attributable to adjustable-rate mortgages (ARMs), from 11 percent in January to 30 percent by August (chart 12). This shift to ARMs likely contrib-

10. Securitized share of outstanding consumer loans originated by banks, 1988-99

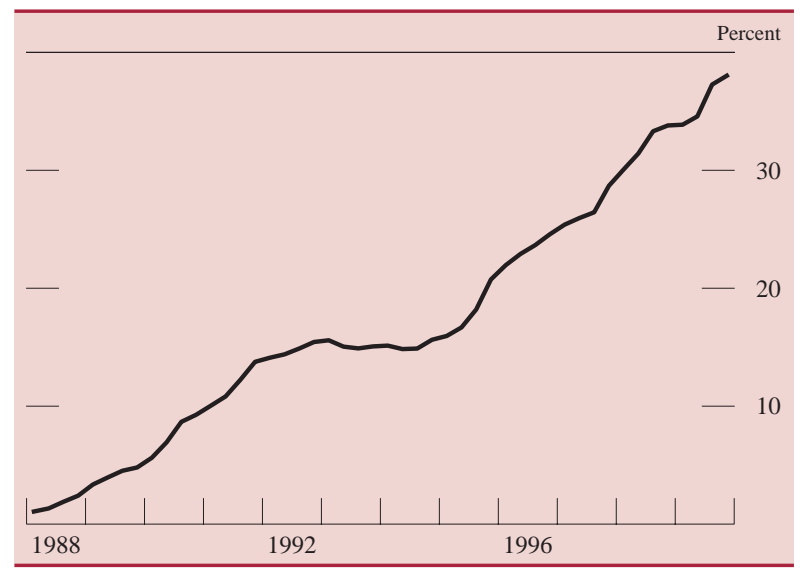

Note. The data are seasonally adjusted.

Source. Federal Reserve Board, Statistical Releases H.8, "Assets and Liabilities of Commercial Banks in the United States," and G.19, "Consumer Credit." 
11. Net percentage of selected commercial banks that tightened standards and terms on credit card loans, 1996-2000:Q1

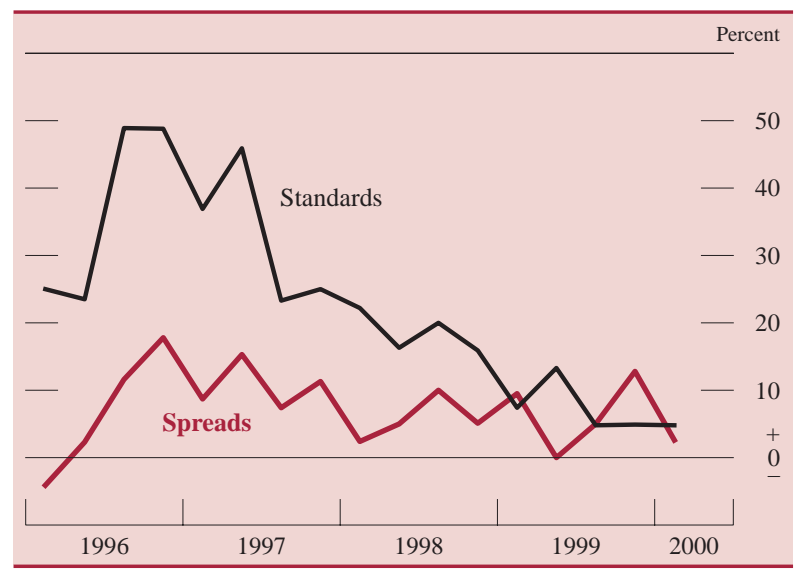

NoTE. Net percentage is the percentage of banks that reported a tightening of standards or terms less the percentage that reported an easing. Tightening or easing of terms represented by increase or decrease respectively in spread of loan yield over bank's cost of funds.

Source. Federal Reserve Board, "Senior Loan Officer Opinion Survey on Bank Lending Practices."

uted to reduced securitizations because the maturities (more precisely, the durations) of ARMs match those of banks' liabilities more closely than do those of fixed-rate mortgages.

Home equity loans increased 5.9 percent in 1999 after having fallen 1.6 percent in 1998. In addition, the ratio of outstanding home equity loans to total commitments declined from 46 percent in 1998 to 42 percent in 1999. During 1998, some households were able to tap into the accumulated equity in their homes directly in the form of cash-out refinancing and use the proceeds to substitute for other debt, including home equity loans. ${ }^{9}$ Thus, the growth in home equity loans and lines (as well as consumer credit) last year may have been supported by the 67 percent plunge in refinancing activity relative to 1998 (chart 13).

\section{Other Loans and Leases}

The other loans and leases category grew 6.4 percent in 1999. Leases, which expanded 22 percent in 1999 , were the fastest growing component and now account for almost one-third of this category, up from about one-seventh in 1994. Loans to depository institutions, the second largest item in this category, expanded only 2 percent in 1999, after advancing 13 percent in 1998. In part, the sluggishness of loans to depository

9. An estimated one-third of homeowners who refinanced their mortgages in 1998 took some cash out as part of the loan.
12. Share of home mortgages originated with adjustable rates, 1990-99

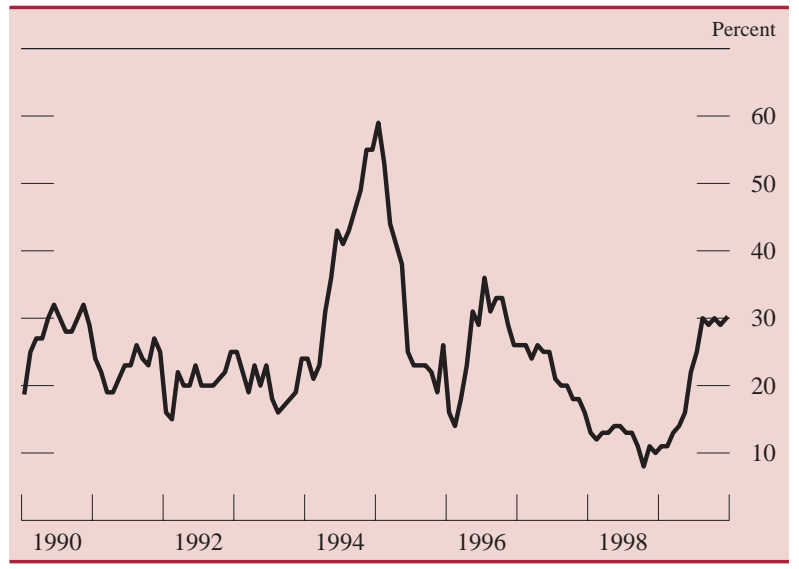

Source. Federal Home Loan Bank Board.

institutions may reflect the increased reliance of commercial banks on loans from the Federal Home Loan Bank System (FHLB), as discussed below.

\section{Securities}

Taking banks' trading and investment accounts together, securities growth slowed in 1999 to a relatively moderate 5.1 percent, down from more than 8 percent per year in the previous two years. Holdings in the trading account fell sharply for a second year; holdings in the investment accounts rose, but more slowly than in 1998.

A significant amount of the slowdown in the investment account was attributable to the effect of rising interest rates on the 86 percent of those assets that were classified as available for sale and therefore carried at market value. At the end of 1999, the

\section{Home mortgage refinancing, 1991-99}

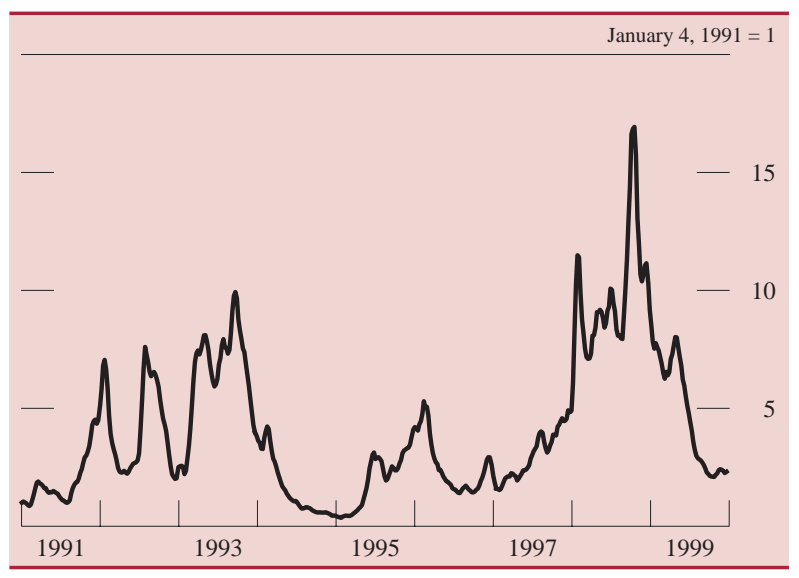

SOURCE. Mortgage Bankers Association. 
market value of these securities was about $\$ 18$ billion less than their book value, whereas at the end of 1998 the market value exceeded the book value by $\$ 10$ billion.

Securities growth in the investment account was also held down by runoffs of securities acquired during the fourth quarter of 1998. This pattern was particularly evident for transactions in mortgagebacked securities, which banks retained in 1998 given the lack of demand for securitized assets during the financial crisis following the Russian default; as market conditions improved in the first half of 1999, banks then sold these securities.

Still, banks' investment accounts rose 6 percent in 1999. Within the investment account, which now comprises more than 18 percent of bank assets, the share represented by Treasury securities edged down, and the share in corporate and other private debt rose correspondingly. Some of the shift away from Treasury securities last year was perhaps the result of the depressing effect that soaring federal budget surpluses have had on the quantity of these securities, driving up the prices, and thus reducing the yields. Equity investments, although still a tiny fraction of total assets, grew rapidly.

Regarding the pullback in trading account assets, the 1998 fall represented a retreat from foreign trading operations, whereas the drop in 1999 was spread about equally across both domestic and foreign offices. At just over 2 percent, the share of assets held in trading accounts is now the lowest it has been since 1992.

\section{Liabilities}

A preference for safety and liquidity during the financial turmoil of the final quarter of 1998 had led to a 21 percent annualized rate of increase in core deposits. In contrast, against the backdrop of increasing market interest rates and soaring prices for technology stocks, deposits on net declined early in 1999, and core deposits were flat for the year as a whole. Transaction deposits shrank an appreciable 9 percent, an acceleration of declines that began in 1994 as a result of retail sweep arrangements. Meanwhile, small time and savings deposits grew less than 4 percent, down from the average of about 9 percent in recent years. As a share of total liabilities, core deposits fell about 3 percentage points, to about 52 percent, after reaching 67 percent as recently as 1992 .

The sluggishness of core deposits led banking institutions to continue to increase their reliance on generally more expensive managed liabilities. Managed liabilities grew faster than total bank assets for the seventh consecutive year, advancing more than 15 percent. Foreign deposits and large time deposits rose at double-digit rates, with most of the increase in conjunction with faster asset growth in the fourth quarter of 1999. In part, the advance in large time deposits during the final quarter of 1999 reflected increased investor demand for safe, liquid assets over the century date change.

The other-managed-liabilities category, which advanced almost 10 percent in 1998 and nearly 18 percent ( $\$ 146$ billion) in 1999 , now represents about 19 percent of total liabilities. ${ }^{10}$ More than 25 percent of that gain was related to an increase in borrowing from the FHLB, which reported that advances to member commercial banks expanded about $\$ 40$ billion during 1999. The FHLB attributed the growth partly to the increasing number of commercial banks joining the system. ${ }^{11}$

\section{Capital}

Growth in equity capital at banks slowed to about 4 percent in 1999 after reaching nearly 10 percent in 1998. However, the slowing was in line with that of asset growth, and the share of assets funded by equity

10. Other managed liabilities include, among other things, federal funds purchased and securities sold under repurchase agreements, loans sold under repurchase agreements that mature in more than one day, sales of participations in pools of loans that mature in more than one day, purchases of term federal funds, as well as borrowings from Federal Reserve Banks and Federal Home Loan Banks.

11. Federal Housing Finance Board, Federal Home Loan Bank System 1999 Financial Report (FHFB, 2000), p. 19.

14. Assets and regulatory capital at well-capitalized banks, 1994-99

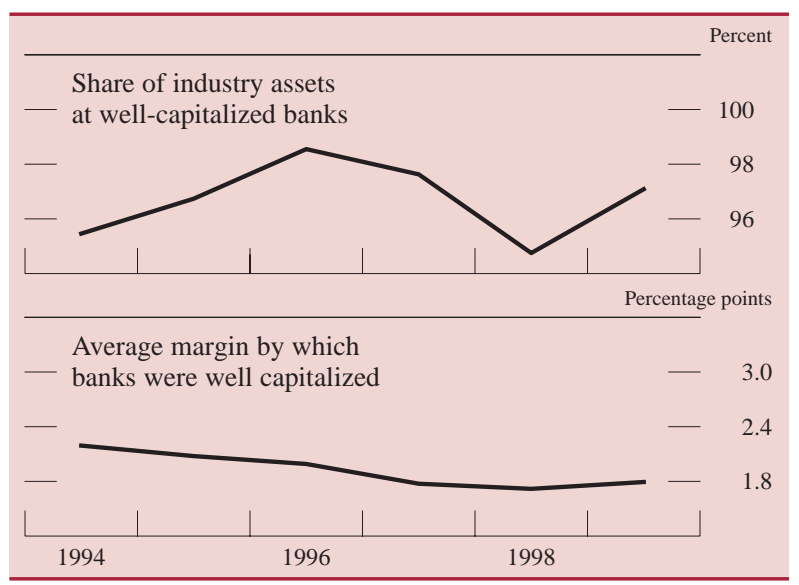

Note. For the definition of well capitalized and of the margin by which banks remain well capitalized, see text note 12 . 


\section{Regulatory capital ratios, 1990-99}

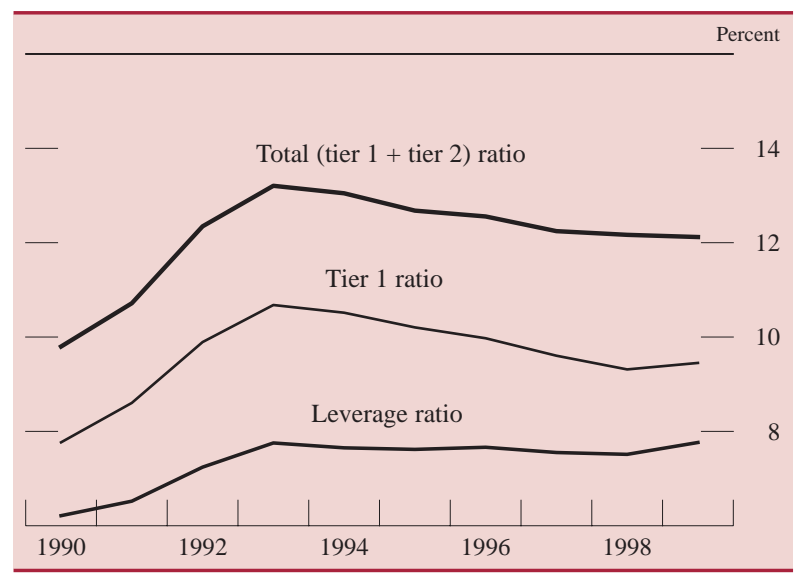

Note. For the definition of capital ratios, see text note 13

was unchanged at 8.5 percent. Banks were able to add $\$ 16$ billion to retained earnings even as they increased dividend payments. They also added about $\$ 19$ billion to paid-in capital, the other source of equity capital. Approximately half of the $\$ 19$ billion represented new capital, a large portion of which came from parent holding companies; the remainder came primarily from the excess of equity issued to fund mergers over the value of the shares retired in those mergers. These additions to equity capital were partially offset, however, by a swing from $\$ 5$ billion in net unrealized gains on available-for-sale securities in 1998 to a $\$ 13$ billion loss last year.

After falling in 1997 and 1998, the percentage of assets held by well-capitalized banks rose to near its 1996 record level (chart 14). In addition, the average margin by which banks remained well capitalized firmed a bit in 1999 after having narrowed significantly in the previous five years. ${ }^{12}$ Tier 1 capital increased 7.5 percent, a rate that exceeded the increase in equity capital mainly because net unrealized gains or losses on debt securities do not affect regulatory capital. The ratio of tier 1 capital to risk-

12. An institution is deemed to be well capitalized if it (1) has a total risk-based capital ratio of at least 10 percent, (2) has a tier 1 risk-based capital ratio of at least 6 percent, (3) has a leverage ratio of at least 5 percent, and (4) is not subject to any written agreement, order, capital directive, or prompt corrective action directive issued by regulatory authorities.

The average margin by which banks remained well capitalized was computed as follows. First, among the leverage, tier 1, and total capital ratios of each well-capitalized bank, the institution's tightest capital ratio is defined as the one closest to the regulatory standard for being well capitalized. The bank's margin is then defined as the percentage point difference between its tightest capital ratio and the corresponding regulatory standard. The average margin among all well-capitalized banks - the measure referred to in the text-is the weighted average of all the individual margins, with the weights being each bank's share of the total assets of well-capitalized banks. weighted assets inched up 14 basis points in 1999 , as risk-weighted assets advanced only 6 percent (chart 15). Tier 2 capital, on the other hand, declined 1 percent, causing the ratio of total capital to riskweighted assets to slip 5 basis points, on balance, to just over 12 percent. ${ }^{13}$ The leverage ratio increased in 1999, as average tangible assets grew only 4 percent.

\section{TRENDS IN PROFITABILITY}

The net income of commercial banks grew 16 percent in 1999 , to $\$ 71.5$ billion. Bank earnings were at record levels in every quarter but the second, when a large bank that was acquired at the end of the quarter posted a $\$ 1.5$ billion net loss. ${ }^{14}$ Even so, the proportion of banks reporting negative net income, which has been rising steadily since 1995, rose again in 1999 , by more than 1 percentage point, to 7.4 percent. With last year's losses more concentrated at the smallest banks, however, the share of the industry's assets at unprofitable banks fell from 2.6 percent in 1998 to 1.5 percent in 1999 , about the midpoint of its range over the past few years and well below the levels registered in the late 1980s and early 1990s.

The industrywide return on assets rebounded 11 basis points last year, to 1.3 percent, after having been depressed significantly by the high level of restructuring charges associated with the frenzied pace of mergers and acquisitions during 1998 (table 2). The return on equity surged 1.4 percentage points, to 15.5 percent, a new record. In turn, dividends, which are paid primarily to parent holding companies, soared more than 26 percent last year, to $\$ 52$ billion. Dividends as a percentage of assets increased 16 basis points last year, to a record 0.96 percent, after having declined 10 basis points in 1998.

13. The tier 1 ratio is the ratio of tier 1 capital to risk-weighted assets, and the total ratio is the ratio of the sum of tier 1 and tier 2 capital to risk-weighted assets. Tier 1 capital consists primarily of common equity (excluding intangible assets such as goodwill and excluding net unrealized gains on investment account debt securities classified as available for sale) and certain perpetual preferred stock. Tier 2 capital consists primarily of subordinated debt, preferred stock not included in tier 1 capital, and loan-loss reserves. Risk-weighted assets are calculated by multiplying the amount of assets and the credit-equivalent amount of off-balance-sheet items (an estimate of the potential credit exposure posed by the item) by the risk weight for each category. The risk weights rise from zero to one as the credit risk of the assets increases. The leverage ratio is the ratio of tier 1 capital to average tangible assets. Tangible assets are equal to total assets less assets excluded from common equity in the calculation of tier 1 capital.

14. Bankers Trust Company of New York, which was acquired by Deutsche Bank AG in June 1999. 
2. Selected income and expense items as a proportion of assets, 1992-99 Percent

\begin{tabular}{|c|c|c|c|c|c|c|c|c|}
\hline Item & 1992 & 1993 & 1994 & 1995 & 1996 & 1997 & 1998 & 1999 \\
\hline Net interest income & 3.89 & 3.90 & 3.78 & 3.72 & 3.73 & 3.67 & 3.52 & 3.53 \\
\hline Noninterest income & 1.95 & 2.13 & 2.00 & 2.02 & 2.18 & 2.23 & 2.41 & 2.66 \\
\hline Noninterest expense & 3.86 & 3.94 & 3.75 & 3.64 & 3.71 & 3.61 & 3.77 & 3.77 \\
\hline Loss provisioning & .78 & .47 & .28 & .30 & .37 & .41 & .41 & .39 \\
\hline Realized gains on investment account securities & .11 & .09 & -.01 & .01 & .03 & .04 & .06 & .00 \\
\hline Income before taxes and extraordinary items & 1.32 & 1.70 & 1.73 & 1.81 & 1.85 & 1.93 & 1.81 & 2.04 \\
\hline Taxes and extraordinary items . & .41 & .50 & .58 & .63 & .65 & .67 & .61 & .72 \\
\hline Net income (return on assets) & .91 & 1.20 & 1.15 & 1.18 & 1.20 & 1.25 & $\begin{array}{l}.01 \\
1.20\end{array}$ & 1.31 \\
\hline Dividends & .41 & .62 & .73 & .75 & .90 & .90 & .80 & .96 \\
\hline Retained income $\ldots \ldots$ & .49 & .58 & .42 & .43 & .30 & .35 & .39 & .36 \\
\hline
\end{tabular}

Strong performance in all key business areas contributed to the record-breaking level of bank profits in 1999. The ratio of noninterest expenses to revenue - a key influence on industry profitability in recent years-resumed its downward trend last year; it had jumped sharply in 1998 because of a high level of charges related to mergers and acquisitions. Noninterest income, which benefited from a sharp pickup in nondeposit fee income and strong gains in trading income, surged almost 17 percent, about three times faster than noninterest expense. In addition, net interest income rose, stabilizing as a percentage of assets after having trended down steadily from the relatively high levels posted in the mid-1990s.

Although widespread by function, the improvement in profitability last year nevertheless was concentrated at large and medium-sized banks. After a dip below 11 percent in 1998, the return on equity at the 10 largest banks shot up 3 percentage points, to 13.6 percent, in 1999 (chart 16). Thus, the profitability of the 10 largest banks (which held 35 percent of the industry's assets at the end of the year) reestab-

\section{Return on equity, by size of bank, 1985-99}

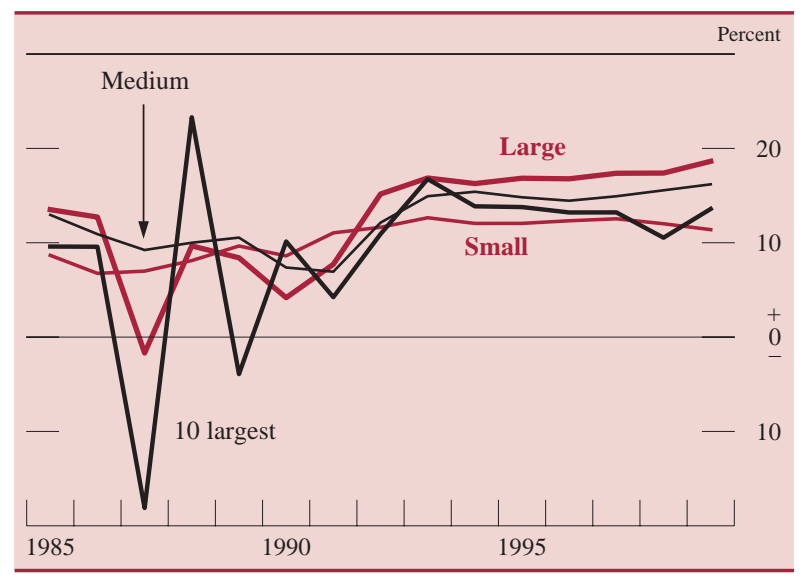

Note. For definition of bank size, see text note 1 . lished itself in the relatively high range of the mid1990s.

At the next 90 largest banks (also accounting for 35 percent of industry assets), the return on equity increased 1.3 percentage points last year, to 18.6 percent, a record high. The return at the next 900 largest banks (18 percent of industry assets) rose 61 basis points, to 16.2 percent, also a new record. For the small banks (12 percent of industry assets) - the remaining 7,600 or so banks smaller than the 1,000 largest - the return on equity declined 60 basis points, to 11.4 percent, the first year since 1992 that this group returned less than 12 percent.

The profitability gap between large and small banks would have been greater but for the growth in recent years in the number of smaller banks that have elected corporate status under subchapter $\mathrm{S}$ of the Internal Revenue Code. ${ }^{15}$ At the end of 1999, about 15 percent of insured commercial banks had claimed $\mathrm{S}$ status and accounted for little more than 2 percent of the industry's assets (table 3 ).

Despite the profitability of their bank subsidiaries, bank holding companies, particularly the large money

15. A subchapter $\mathrm{S}$ corporation is generally not subject to federal taxes at the corporate level, and its net income can therefore be as much as one-half higher than the income of a comparable bank that does not have subchapter $\mathrm{S}$ status. For many banks, the main impediment to claiming $\mathrm{S}$ status is the restriction on the maximum number of shareholders, which currently stands at seventy-five, and the fact that stockholders cannot be other companies.

3. Banks claiming corporate status under subchapter $\mathrm{S}$ of the Internal Revenue Code, year-end 1997-99

Percent

\begin{tabular}{c|c|c|c|c}
\hline Year & Number & $\begin{array}{c}\text { Percentage } \\
\text { of all banks }\end{array}$ & $\begin{array}{c}\text { Percentage } \\
\text { of assets of } \\
\text { all banks }\end{array}$ & $\begin{array}{c}\text { MEMo: } \\
\text { Number of } \\
\text { all banks }\end{array}$ \\
\hline $1997 \ldots \ldots \ldots \ldots$ & 601 & 6.5 & .9 & 9,188 \\
$1998 \ldots \ldots \ldots \ldots$ & 1,041 & 11.8 & 1.6 & 8,815 \\
$1999 \ldots \ldots \ldots \ldots$ & 1,283 & 14.9 & 2.0 & 8,620 \\
\hline
\end{tabular}

Note. For definition of subchapter $\mathrm{S}$ status, see text note 15 . 
17. Indexes of bank holding company stock prices and the S\&P 500, 1999-April 28, 2000

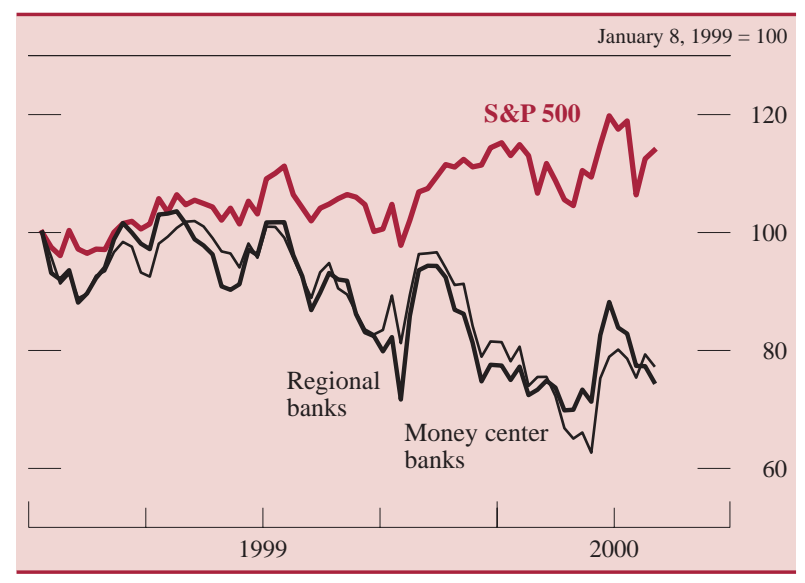

Note. The holding company indexes are for four money center bank holding companies and twenty-five regional bank holding companies as defined by Standard and Poor's.

Source. Standard and Poor's.

center banks, ended the year with their stock prices down as much as 20 percent compared with the beginning of the year (chart 17), whereas the S\&P 500 and most other broad stock indexes rose over the course of the year.

The poor performance of the banking sector's equity prices was likely due to two factors. First, the rise in money market interest rates and the prime rate that began around midyear added to the interest burden on bank borrowers and raised the likelihood of an economic slowdown. Such developments increase the possibility of higher loan charge-off rates and loan loss provisioning and lowered future bank earnings.

Second, the earnings results of several large-scale bank mergers fell short of expectations last year. In particular, compared with analysts' initial forecasts, six large banks that were involved in mergers in 1997 and 1998 collectively generated an earnings shortfall of more than \$5 billion during 1999.

\section{Interest Income and Expense}

Although market interest rates rose in the latter part of 1999, they were lower on average for the year than in 1998, and banks' interest income and interest expense as a percentage of their average interestearning assets fell about 30 basis points last year. As a result, the industrywide net interest margin, or the ratio of net interest income to average interestearning assets, remained about unchanged at roughly 4.1 percent in 1999 (chart 18, top).
18. Net interest margin, by size of bank, 1985-99

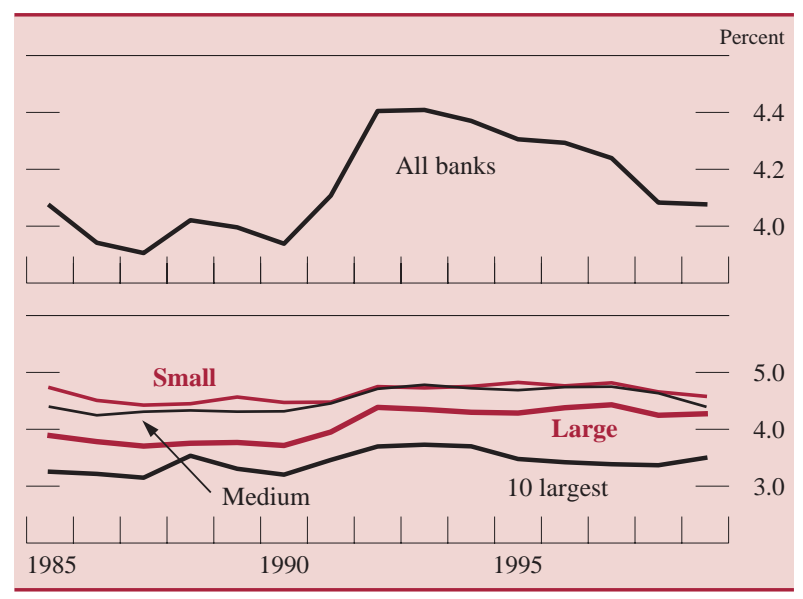

Note. Net interest margin is net interest income divided by average interestearning assets. For definition of bank size, see text note 1.

The net interest margin last year was above the levels of the late 1980s but well below the levels of the early 1990s, when diminished competition for deposit funds in a time of sluggish economic growth, plus a desire to curb asset growth to improve capital positions, resulted in deposit rates falling more than loan rates. The steady narrowing of the net interest margin since 1993 reflects a confluence of two factors: aggressive loan pricing and the increased reliance on managed liabilities. ${ }^{16}$

The decline in the industrywide net interest margin halted last year as banks became less accommodative late in 1998 and continued to tighten lending terms throughout 1999. As noted, respondents to the BLPS reported higher spreads on business loans throughout 1999, and evidence from the STBL indicates that the spreads on C\&I loan originations during 1999 edged higher, especially for riskier loans.

The industrywide results mask important differences, however, in the behavior of the net interest margin across different bank sizes (chart 18, bottom). For all but the 100 largest banks, the net interest margin declined last year. The decline was particularly apparent for medium-sized banks (ranked 101 through 1,000), which saw their net interest margin slump 23 basis points, to 4.4 percent, a level not seen since the early 1990s. For small banks, the net interest margin declined 8 basis points and, at the end of 1999 , stood considerably below the elevated levels of the mid-1990s. The net interest margin at the top 10 banks, on the other hand, climbed 13 basis

16. For historical perspective on the net interest margin, see Antulio N. Bomfim and William R. Nelson, "Profits and Balance Sheet Developments at U.S. Commercial Banks in 1998," Federal Reserve Bulletin, vol. 85 (June 1999), p. 379. 
19. Noninterest income and its components as a share of total revenue, 1985-99

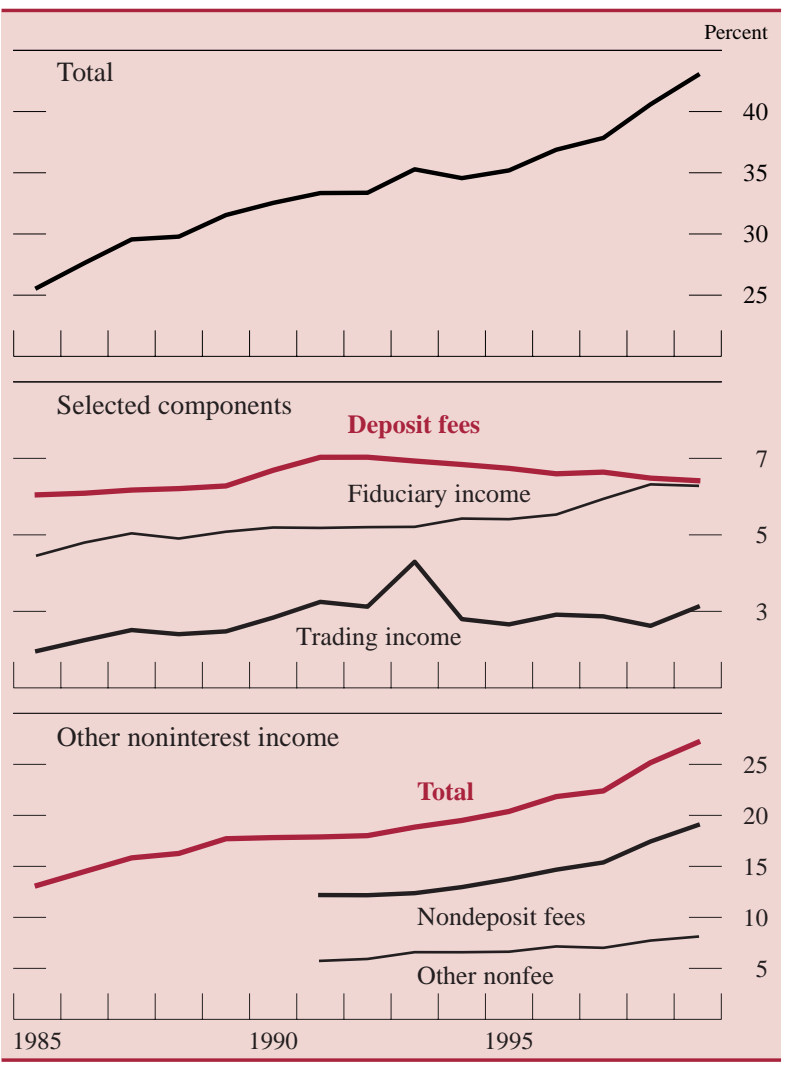

Note. Components of "other noninterest income" were first included in the March 1991 Call Report.

points last year, to 3.5 percent, ending the string of declines that began in 1994. At the next largest 90 banks, the net interest margin edged up 2 basis points.

\section{Noninterest Income and Expense}

Contributing importantly to the industry's record profitability, noninterest income rose 25 basis points as a percent of assets last year-the largest annual gain on record-and increased nearly 2.5 percentage points as a share of revenue. At the end of 1999, noninterest income accounted for 43 percent of commercial banks' total revenue, up 10 percentage points over the past decade (chart 19, top).

The surge in noninterest income last year was concentrated in trading income (chart 19, middle) and in the "nondeposit fee income" component of other noninterest income (chart 19, bottom), both categories reflecting activities of large banks. Nondeposit fee income, which jumped 1.6 percentage points as a share of revenue last year, includes credit card fees, mortgage servicing and refinancing fees,
20. Off-balance-sheet securities lent, 1989-99

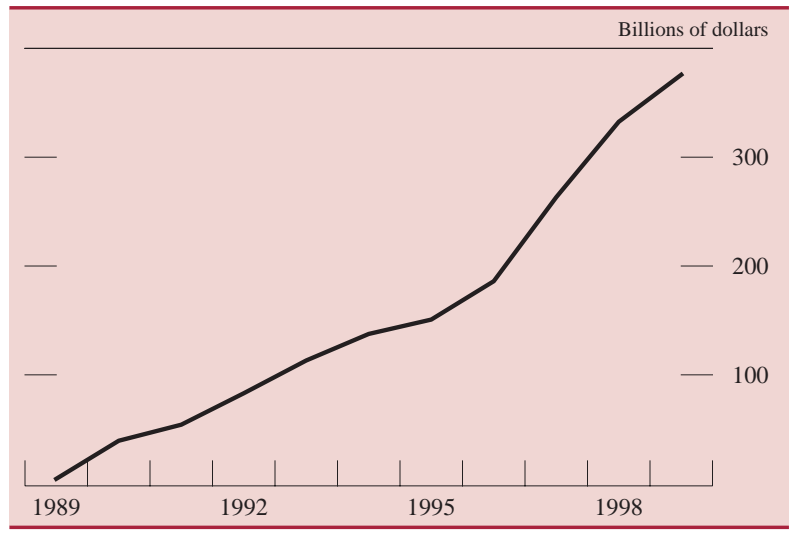

fees from the sale and servicing of mutual funds and annuities, ATM surcharges, and fee income from securitized loans and securities lending.

Although no data on the individual elements of nondeposit fee income are available, the increase last year probably reflected, in part, the continued growth in the share of bank loans, especially consumer loans that are securitized. In addition, the rapid growth of securities lending over the past decade (chart 20), spurred on by the desire to increase earnings on assets held in trust, has also likely contributed to the increase in nondeposit fees. ${ }^{17}$ The major negative element in nondeposit fee income was probably the plunge in mortgage refinancing activity, for which banks collect processing fees.

Trading income as a share of revenue grew a sharp $1 / 2$ percentage point, finishing the year above 3 percent for the first time since 1993 (chart 19). The jump in trading revenue was driven by a five-fold increase in income earned on equity, commodity, and other exposures (table 4). Revenue from equity exposures

17. Banks lend securities on behalf of their trust customers, typically pension funds and some other large institutional investors, to increase earnings on assets held in trust. In the case of most transactions, banks receive cash as collateral, which, in turn, they invest. The trust benefits both from the interest earned on the invested cash collateral and from the excess of cash collateral received over the value of the securities lent. The bank benefits from the fees it earns.

4. Trading revenue at all U.S. banks, by type of exposure, 1995-99

Millions of dollars

\begin{tabular}{c|r|c|c|c}
\hline Year & Total & $\begin{array}{c}\text { Interest } \\
\text { rate }\end{array}$ & $\begin{array}{c}\text { Foreign } \\
\text { exchange }\end{array}$ & $\begin{array}{c}\text { Equity, } \\
\text { commodity, } \\
\text { and other }\end{array}$ \\
\hline $1995 \ldots \ldots$ & 6,337 & 3,012 & 2,491 & 635 \\
$1996 \ldots \ldots$ & 7,526 & 4,112 & 2,689 & 725 \\
$1997 \ldots \ldots$ & 8,020 & 3,995 & 3,951 & 72 \\
$1998 \ldots \ldots$ & 7,994 & 2,469 & 5,170 & 355 \\
$1999 \ldots \ldots$ & 10,486 & 3,846 & 4,813 & 1,825 \\
\hline
\end{tabular}


21. Dollar volume of initial public offerings, 1991-99

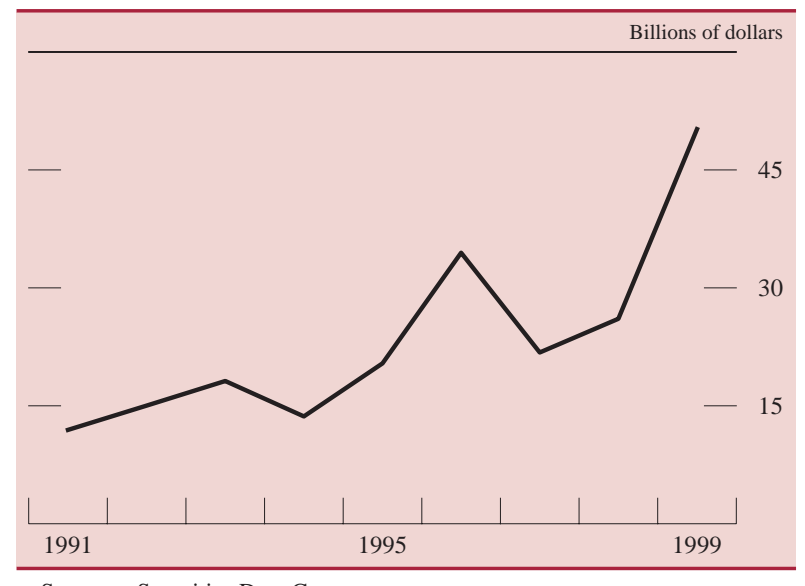

Source. Securities Data Company.

soared more than 300 percent during 1999, and trading income earned on interest rate exposures shot up 56 percent. Trading income earned on foreign exchange exposures remained robust last year, although it declined about 7 percent from the very high level posted in 1998.

The nonfee component of other noninterest income advanced nearly 40 basis points as a share of revenue last year. This category includes income from professional services, such as those provided for holding company affiliates; gains on the sale of assets other than securities, such as loans and bank branches; and income from venture capital activities. Gains on the venture capital activities of banks' small business investment subsidiaries are also booked in this category. The record dollar amount of IPOs last year suggests that this category contributed importantly to the growth of the nonfee component (chart 21). Both deposit fees and fiduciary income as a share of revenue edged down about 5 basis points last year, although fiduciary income remained at an elevated level relative to historical norms.

Noninterest expense as a share of revenue dropped 2.5 percentage points last year after having spiked up in 1998 (chart 22, top). The 1998 spike was produced by growth of nearly 18 percent in the broad "other noninterest expense" category (chart 22, bottom), which accounts for nearly half of total noninterest expense and includes charges for mergers and restructuring and for data processing services. As noted, merger activity was much higher in 1998 than 1999 , and the slowdown in that activity probably caused the deceleration in the growth rate of other noninterest expense to just 3 percent and the decline in noninterest expense as a whole. Charges for computer services were likely high in both 1998 and
22. Noninterest expense as a proportion of revenue, 1985-99

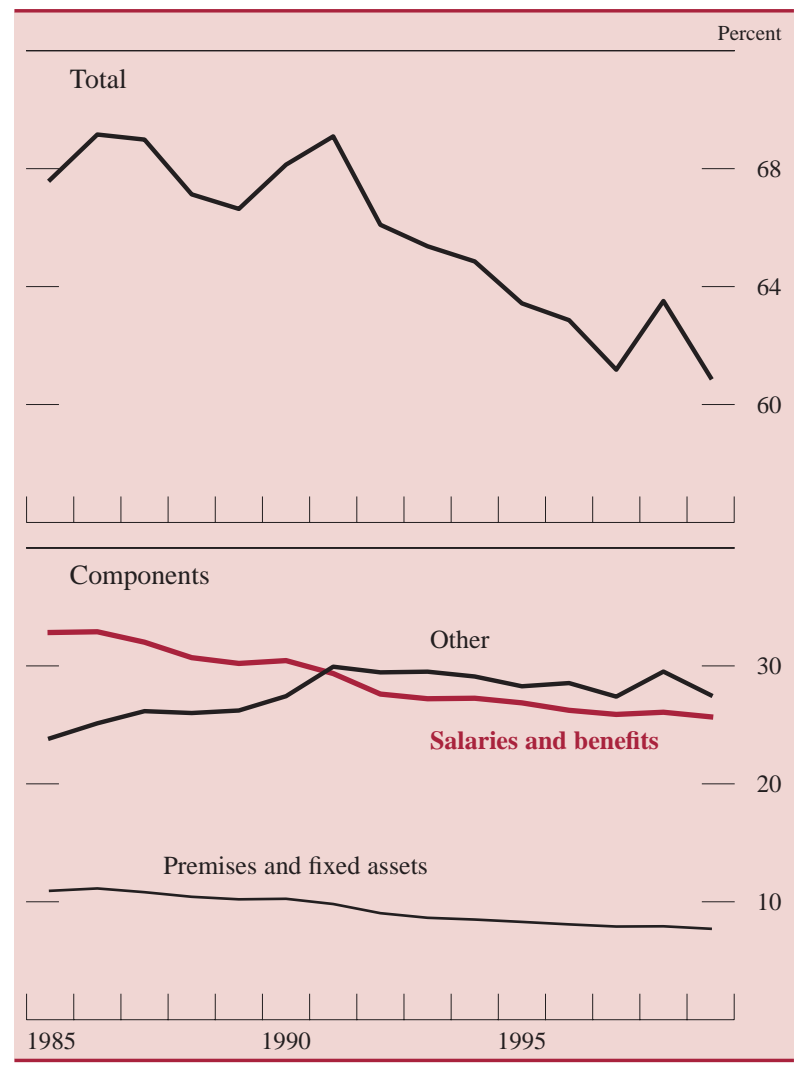

1999, given the effort to ensure computer system readiness for the century date change.

The growth of noninterest expense was also damped by slowdowns in the industry's growth of wages and occupancy costs last year, both of which retreated significantly from the 10 percent pace they each posted in 1998. The rise in labor costs was restrained in part because employment, which had advanced 4.3 percent in 1998, rose less than 3 percent last year, perhaps because of the high level of industry mergers and acquisitions in recent years. With revenue growing faster than employment, revenue per employee increased 7.3 percent, more than offsetting the 5.5 percent rise in employment costs per employee. The decline in the growth of occupancy costs last year may also have reflected mergers and acquisitions (which can reduce the need for office space) and a significant slowdown in the rise of office rents.

\section{Loan Performance and Loss Provisioning}

Profitability last year was supported by good overall loan performance, as most indicators of asset quality showed few signs of deterioration. Reflecting the 
23. Delinquency and charge-off rates for loans to businesses and households, by type of loan, 1991-99

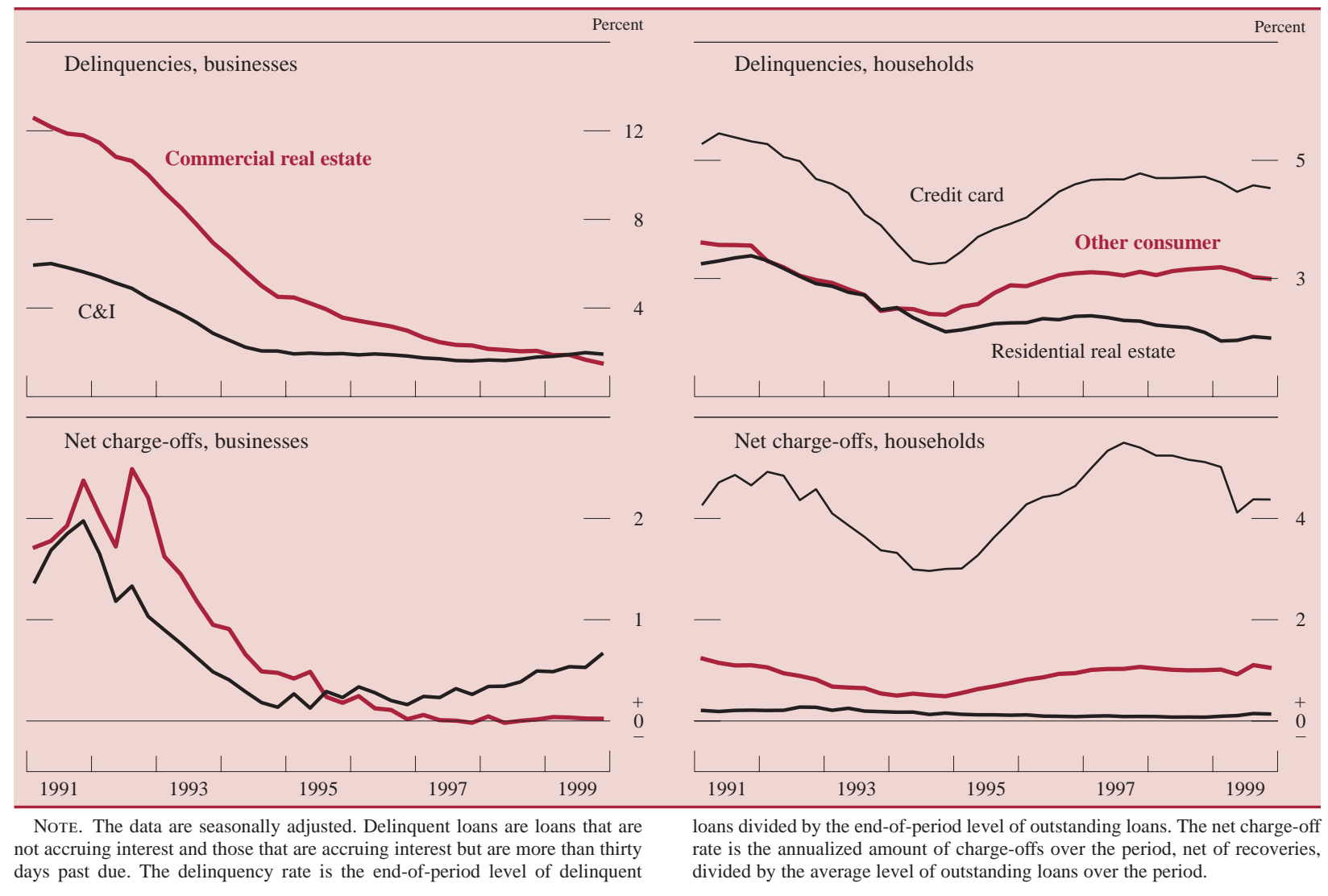

strong market for office and commercial space, delinquency and charge-off rates on commercial mortgages remained at very low levels last year (chart 23, left). The delinquency and charge-off rates on C\&I loans both rose last year but remained fairly low by historical standards.

The pickup in C\&I charge-offs was driven entirely by an increase in loss rates on C\&I loans booked at domestic offices. Evidence from a recent BLPS indicates that problem C\&I loans at domestic commercial banks have been largely confined to specific industries, particularly health care. The charge-off rate on C\&I loans booked abroad, which accounted for about 18 percent of all C\&I loans last year, held steady in the elevated range posted in the aftermath of financial turmoil in the second half of 1998. Delinquencies and charge-off rates on agricultural production loans also rose early last year, likely because of low prices for agricultural products and increases in production costs.

The ratio of charge-offs to delinquencies on C\&I loans increased for the second consecutive year in 1999 and now stands in the range comparable to that of the 1990-91 recession. In addition to the concentration of C\&I loans in certain troubled industries, such as health care, a factor boosting delinquency and charge-off rates may be the "seasoning"- the increase in the age - of outstanding C\&I loans. The longer a loan remains in a portfolio, the greater the probability of its delinquency and default.

Two factors may be contributing to the seasoning of banks' C\&I loan portfolio. The first is the slowing in the growth of business loan originations, from 12 percent in 1997 and 1998 to 8 percent last year. When loan growth decelerates, the resulting reduction in the share of new loans in the portfolio can raise the average delinquency rate in the short run; the opposite effect occurs when loan growth accelerates. Second, according to the STBL, the average maturity of C\&I loan originations has risen significantly over the past several years (chart 24). An increase in the maturity of loan originations would eventually raise the average age of outstanding loans in the portfolio.

The quality of household loans improved last year, but the overall picture remains mixed. The delinquency rate on credit card loans, while declining 10 basis points, remained on the high side of historical norms. The net charge-off rate on credit card loans declined for the second consecutive year, but 
24. Average maturity of new C\&I loans, 1991-99

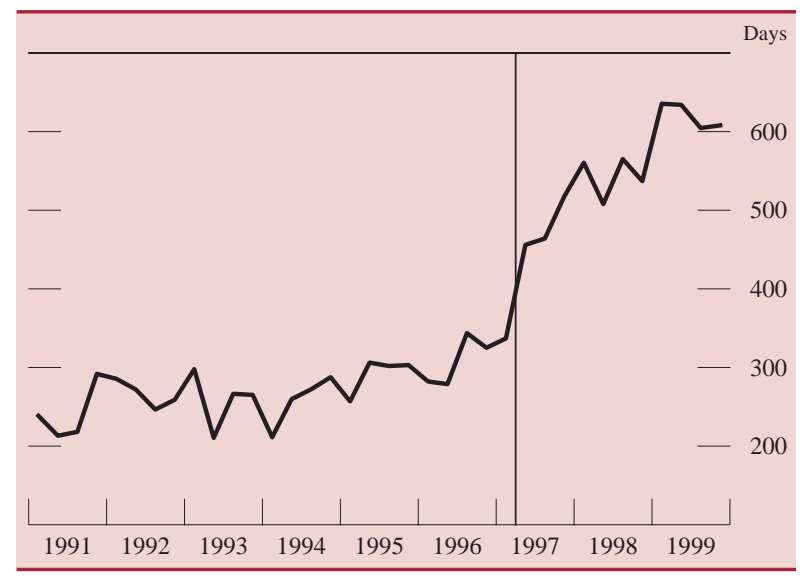

NoTE. Vertical line denotes change in composition of survey panel after the first quarter of 1997.

Source. Federal Reserve Board, Statistical Release E.2, "Survey of Terms of Business Lending."

it too remained at an elevated level. A similar picture is presented by delinquency and charge-off rates on other consumer loans. By contrast, the delinquency rate on single-family home mortgages fell 20 basis points, to below 2 percent, an exceptionally low level, while the charge-off rate was essentially unchanged, also at a low level (chart 23, right).

Despite the slight deterioration in the quality of the C\&I loan portfolio, the financial condition of the nonfinancial business sector remained generally positive. The aggregate debt-service burden for nonfinancial corporations-measured by the ratio of net interest payments to cash flow-increased somewhat in 1999 but stayed in a low range relative to historical levels (chart 25).

25. Debt burden of businesses and households, 1985-99

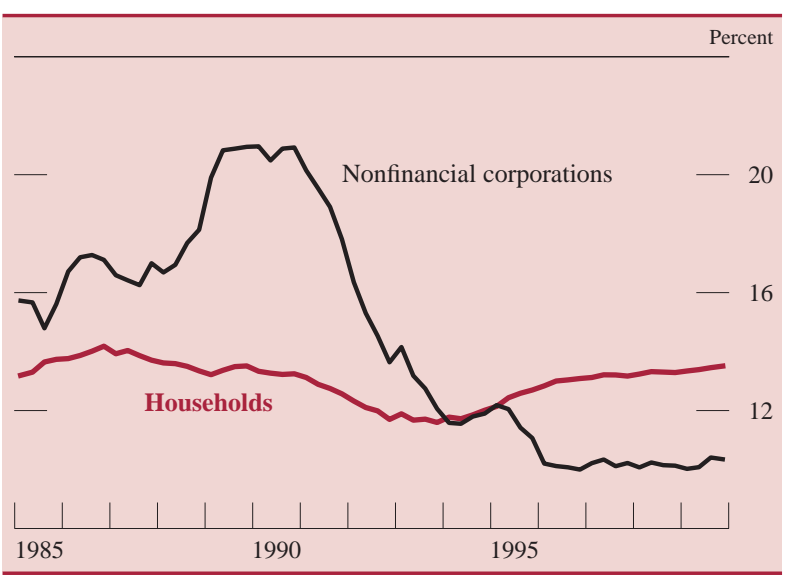

NoTE. The debt burden for nonfinancial corporations is calculated as interest payments as a percentage of cash flow. The debt burden for households is an estimate of the ratio of debt payments to disposable personal income; debt payments consist of the estimated required payments on outstanding mortgage and consumer debt.

SourCE. National income and product accounts and the Federal Reserve System.
On the household side, debt burden, as measured by the sum of interest payments and required principal payments as a fraction of disposable income, increased last year and moved closer to the high levels of the middle and late 1980s (chart 25). On a positive note, the number of personal bankruptcies filed last year retreated significantly from the record level posted at the end of 1998.

The exceptional strength of the economy in 1999 clearly contributed to the continued favorable trend in overall loan performance. However, a slowdown in income carries with it the prospect of greater loan losses. As has been the case for several years, loan loss provisioning last year was only a bit above loan charge-offs.

Given the robust growth in loans, reserves for loan and lease losses as a percentage of loans and leases continued their downward trend. At the end of last year, the fraction stood at about 1.8 percent (chart 26, top), more than 40 basis points below the average level of the past fifteen years. Relative to delinquent loans, however, loan-loss reserves remained elevated, although the ratio declined slightly last year

26. Reserves, provisioning, and charge-offs for loan and lease losses, 1985-99

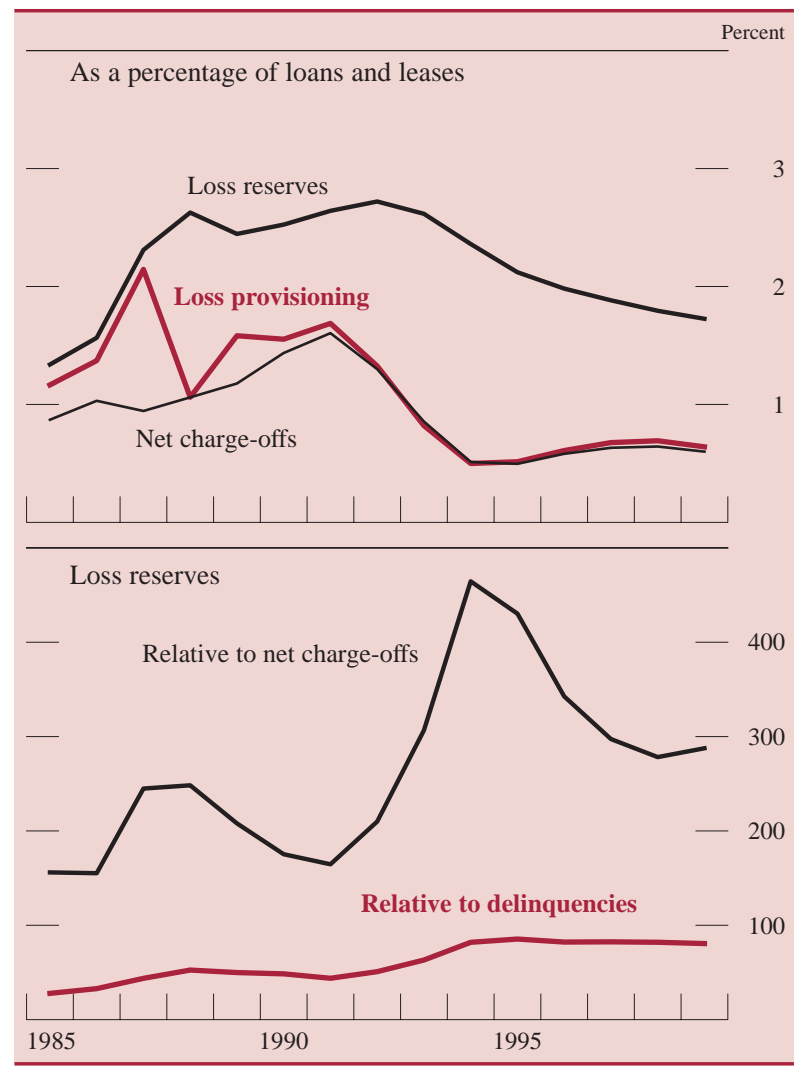

Note. For definitions of delinquencies and net charge-offs, see note to chart 23. 
5. Exposure of selected U.S. banking organizations to selected economies at year-end, relative to tier 1 capital, 1997-99 Percent except as noted

\begin{tabular}{|c|c|c|c|c|c|c|c|c|c|c|c|c|}
\hline \multirow[t]{2}{*}{ Region or country } & \multicolumn{3}{|c|}{ All reporting } & \multicolumn{3}{|c|}{$\begin{array}{c}\text { Money center } \\
\text { and other large banks }\end{array}$} & \multicolumn{3}{|c|}{ Other } & \multicolumn{3}{|c|}{$\begin{array}{c}\text { Mемо: } \\
\text { Total exposure, } \\
\text { all reporting banks } \\
\text { (billions of dollars) }\end{array}$} \\
\hline & 1997 & 1998 & 1999 & 1997 & 1998 & 1999 & 1997 & 1998 & 1999 & 1997 & 1998 & 1999 \\
\hline $\begin{array}{r}\text { Selected Asian } \\
\text { countries }^{1}\end{array}$ & 27.11 & 15.49 & 14.37 & 43.76 & 24.02 & 20.73 & 3.90 & 2.08 & 1.75 & 55.24 & 37.87 & 37.45 \\
\hline \multicolumn{13}{|l|}{$\begin{array}{l}\text { Eastern Europe and } \\
\text { Russia }\end{array}$} \\
\hline & 5.84 & 3.49 & 2.85 & 9.97 & 5.61 & 4.25 & .14 & .16 & .08 & 11.91 & 8.53 & 7.43 \\
\hline Russia ..... & 3.02 & .43 & .37 & 5.15 & .68 & .55 & .08 & .00 & .01 & 6.16 & 1.05 & .95 \\
\hline \multicolumn{13}{|l|}{ Latin America } \\
\hline & 49.92 & 42.93 & 39.00 & 78.78 & 64.20 & 53.90 & 9.54 & 9.51 & 9.41 & 101.73 & 104.96 & 101.63 \\
\hline Brazil ....... & 16.39 & 11.27 & 10.49 & 26.28 & 17.04 & 14.53 & 2.59 & .00 & 2.47 & 33.40 & 27.55 & 27.34 \\
\hline Total . & 82.87 & 61.90 & 56.22 & 132.51 & 93.83 & 78.88 & 13.57 & 11.75 & 11.24 & 168.89 & 151.36 & 146.51 \\
\hline \multicolumn{6}{|c|}{$\begin{array}{l}\text { Note. Tier } 1 \text { capital for } 1997 \text { is estimated; for definition of tier } 1 \text { capital, see } \\
\text { text note } 13 \text {. Exposures consist of lending and derivatives exposures for cross- } \\
\text { border and local-office operations. Respondents may file information on one } \\
\text { bank or on the bank holding company as a whole. } \\
\text { At year-end } 1999 \text {, "all reporting" banks consisted of } 104 \text { institutions with a } \\
\text { total of } \$ 261 \text { billion in tier } 1 \text { capital; of these institutions, } 6 \text { were money center }\end{array}$} & \multicolumn{7}{|c|}{$\begin{array}{l}\text { banks ( } \$ 133 \text { billion in tier } 1 \text { capital), } 5 \text { were "other large" banks ( } \$ 40 \text { billion), } \\
\text { and the remaining } 93 \text { were "other" banks ( } \$ 87 \text { billion). The average "other" } \\
\text { bank at year-end } 1999 \text { had } \$ 13 \text { billion in assets. } \\
\text { 1. Indonesia, Korea, Malaysia, Philippines, and Thailand. } \\
\text { Source. Federal Financial Institutions Examination Council Statistical } \\
\text { Release E.16, "Country Exposure Survey," available at www.ffiec.gov/E16/ }\end{array}$} \\
\hline
\end{tabular}

(chart 26, bottom); relative to net charge-offs, loanloss reserves posted their first increase since 1994 and are now near the middle of their historical range. The firming in the ratio of reserves to net charge-offs last year owes much to the decline in charge-offs on consumer loans.

\section{INTERNATIONAL OPERATIONS OF U.S. BANKS}

The share of U.S. bank assets booked at foreign offices ticked down a bit in 1999, to 13 percent, after having fallen 2 percentage points in 1998 because of jitters surrounding many developing economies. ${ }^{18}$ Strong income from foreign operations during the first quarter of 1999 helped boost the share of income attributable to such operations to 9.75 percent last year, up from 8.5 percent in the previous year. The rise in income was almost entirely attributable to a rebound in noninterest income, which in turn had been depressed in 1998 by the large trading losses that stemmed from the Russian default.

The exposure of U.S. commercial banks to Russia and to Eastern European, Latin American, and selected Asian economies slipped in 1999 after having fallen about 10 percent from year-end 1997 to year-end 1998 (table 5). On a percentage basis, banks cut their exposure to Eastern Europe and Russia by the largest amount last year; however, their

18. For additional details on the international operations of U.S. banks, see English and Nelson, "Profits and Balance Sheet Developments at U.S. Commercial Banks in 1997," p. 406. total exposure to this area remained small-only 2.85 per cent of tier 1 capital at the end of 1999 . The exposure of money center and other large banks to Latin America declined more than 10 percentage points, even as Moody's upgraded Mexico's sovereign debt to investment grade and the Brazilian economy rebounded after shaking off the effects of the devaluation of the real in January 1999.

\section{RECENT DEVELOPMENTS}

By the end of April 2000, the intended level of the federal funds rate had increased 50 basis points from its level at the end of 1999; the economy, however, appeared to be sustaining its momentum. The banking industry remained healthy, with high profits, good loan performance, and strong demand for credit. Many large bank holding companies, especially those with large securities underwriting and trading operations, reported higher than expected profits during the first three months of 2000. Core loan categories have continued to grow rapidly, while investments in securities have picked up a bit.

Bank holding company stocks, particularly those of money center banks, benefited briefly in late March from a swing by investors away from the technology sector to the so-called "old economy" stocks. By the end of April, however, the stock prices of money center bank holding companies were down 3.6 percent from year-end 1999, and those of regional banks were about 5 percent lower. Both had slightly underperformed the broader market, as measured by the S\&P 500. 
A new era in the financial services industry officially arrived when the Gramm-Leach-Bliley Act became effective on March 11. Shortly thereafter, the Federal Reserve Board announced that it had approved the applications of 117 bank holding companies and foreign banking concerns that had filed to become financial holding companies under the new law. These new entities will be allowed to merge with insurance companies and investment banks as well as to engage in numerous other previously restricted lines of business, most notably merchant banking. 
A.1. Report of income, all U.S. banks, 1990-99 Millions of dollars

\begin{tabular}{|c|c|c|c|c|c|c|c|c|c|c|}
\hline Item & 1990 & 1991 & 1992 & 1993 & 1994 & 1995 & 1996 & 1997 & 1998 & 1999 \\
\hline Gross interest income & 320,404 & 290,692 & 256,415 & 244,742 & 257,064 & 302,376 & 313,115 & 338,230 & 359,166 & 367,203 \\
\hline Taxable equivalent & 324,054 & 293,879 & 259,394 & 247,620 & 259,821 & 305,010 & 315,575 & 340,664 & 361,629 & 369,840 \\
\hline Loans $\ldots \ldots \ldots \ldots$. & 238,829 & 215,019 & 185,938 & 178,425 & 189,762 & 227,218 & 239,307 & 255,504 & 270,942 & 279,321 \\
\hline Securities $\ldots \ldots \ldots \ldots \ldots \ldots \ldots \ldots$ & 51,031 & 52,769 & 51,825 & 48,678 & 48,299 & 51,030 & 50,601 & 52,662 & 56,597 & 62,389 \\
\hline $\begin{array}{l}\text { Gross federal funds sold and reverse } \\
\text { repurchase agreements } \ldots \ldots \ldots \ldots\end{array}$ & 12,571 & 9,149 & 5,913 & 4,796 & 6,415 & 9,744 & 9,265 & 13.658 & 14.997 & 12,333 \\
\hline Other $\ldots \ldots \ldots \ldots \ldots \ldots \ldots \ldots \ldots \ldots \ldots$ & 17,971 & 13,757 & 12,739 & 12,843 & 12,587 & 14,382 & 13,944 & 16,407 & 16,627 & 13,160 \\
\hline Gross interest expense & 204,949 & 168,492 & 122,517 & 105,615 & 110,849 & 147,958 & 150,045 & 164,516 & 177,990 & 175,341 \\
\hline Deposits...$\ldots \ldots \ldots$ & 161,483 & 139,431 & 98,809 & 79,503 & 79,106 & 105,329 & 107,465 & 117,351 & 125,208 & 119,964 \\
\hline $\begin{array}{l}\text { Gross federal funds purchased and } \\
\text { repurchase agreements ........ }\end{array}$ & 22,778 & 14,439 & 9,263 & 8,442 & 12,476 & 18,424 & 16,775 & 20,440 & 22,182 & 21,203 \\
\hline Other $\ldots \ldots \ldots \ldots \ldots \ldots \ldots \ldots \ldots$ & 20,687 & 14,623 & 14,441 & 17,669 & 19,269 & 24,204 & 25,806 & 26,724 & 30,599 & 34,174 \\
\hline Net interest income .... & 115,455 & 122,200 & 133,898 & 139,127 & 146,215 & 154,418 & 163,070 & 173,714 & 181,176 & 191,862 \\
\hline Taxable equivalent & 119,105 & 125,387 & 136,877 & 142,005 & 148,972 & 157,052 & 165,530 & 176,148 & 183,639 & 194,499 \\
\hline Loss provisioning ${ }^{1}$ & 32,282 & 34,871 & 26,813 & 16,841 & 10,993 & 12,631 & 16,206 & 19,173 & 21,197 & 21,054 \\
\hline Noninterest income $\ldots \ldots \ldots \ldots$ & 55,684 & 61,124 & 67,044 & 75,847 & 77,223 & 83,851 & 95,278 & 105,775 & 123,779 & 144,586 \\
\hline Service charges on deposits $\ldots$ & 11,446 & 12,884 & 14,126 & 14,898 & 15,281 & 16,057 & 17,042 & 18,558 & 19,770 & 21,589 \\
\hline Income from fiduciary activities & 8,886 & 9,499 & 10,452 & 11,199 & 12,124 & 12,890 & 14,288 & 16,604 & 19,272 & 21,136 \\
\hline Trading income $\ldots \ldots \ldots \ldots \ldots$ & 4,854 & 5,954 & 6,273 & 9,238 & 6,249 & 6,337 & 7,526 & 8,020 & 7,994 & 10,486 \\
\hline Other.$\ldots \ldots \ldots \ldots$ & 30,497 & 32,785 & 36,193 & 40,513 & 43,572 & 48,567 & 56,421 & 62,593 & 76,746 & 91,374 \\
\hline Noninterest expense $\ldots \ldots \ldots \ldots \ldots \ldots$ & 116,606 & 126,665 & 132,815 & 140,523 & 144,905 & 151,137 & 162,399 & 170,995 & 193,679 & 204,958 \\
\hline Salaries, wages, and employee benefits & 52,111 & 53,810 & 55,484 & 58,507 & 60,904 & 64,013 & 67,775 & 72,347 & 79,505 & 86,399 \\
\hline Expenses of premises and fixed assets & 17,547 & 17,984 & 18,152 & 18,578 & 18,978 & 19,760 & 20,883 & 22,082 & 24,158 & 25,943 \\
\hline Other $\ldots \ldots \ldots \ldots \ldots \ldots \ldots \ldots \ldots \ldots \ldots \ldots$ & 46,948 & 54,871 & 59,181 & 63,439 & 65,023 & 67,363 & 73,741 & 76,567 & 90,018 & 92,616 \\
\hline Net noninterest expense & 60,922 & 65,541 & 65,771 & 64,676 & 67,682 & 67,286 & 67,121 & 65,220 & 69,900 & 60,372 \\
\hline $\begin{array}{r}\text { Realized gains on investment account } \\
\text { securities } \ldots \ldots \ldots \ldots \ldots \ldots \ldots \ldots\end{array}$ & 474 & 2,897 & 3,957 & 3,054 & -560 & 481 & 1,123 & 1,826 & 3,087 & 251 \\
\hline $\begin{array}{l}\text { Income before taxes and extraordinary } \\
\text { items } \ldots \ldots \ldots \ldots \ldots \ldots \ldots\end{array}$ & 22,725 & 24684 & 45273 & 60662 & 66989 & 74.980 & 80.864 & & & 110.689 \\
\hline Taxes $\ldots \ldots \ldots \ldots \ldots$ & 7,749 & 8,292 & 14,450 & 19,861 & 22,430 & 26,222 & 28,430 & 31,989 & 31,909 & 39,410 \\
\hline Extraordinary items & 650 & 1,198 & 401 & 2,085 & -17 & 28 & 88 & 56 & 506 & 169 \\
\hline Net income & 15,626 & 17,590 & 31,224 & 42,886 & 44,542 & 48,785 & 52,521 & 59,212 & 61,478 & 71,447 \\
\hline Cash dividends declared & 13,965 & 15,562 & 14,226 & 22,068 & 28,164 & 31,105 & 39,391 & 42,726 & 41,304 & 52,123 \\
\hline Retained income ....... & 1,661 & 2,028 & 16,997 & 20,816 & 16,377 & 17,681 & 13,131 & 16,486 & 20,174 & 19,324 \\
\hline
\end{tabular}

1. Includes provisions for loan and lease losses and for allocated transfer risk.

Table A.2 begins on page 386. 
A.2. Portfolio composition, interest rates, and income and expense, all U.S. banks, 1990-99 A. All banks

\begin{tabular}{|c|c|c|c|c|c|c|c|c|c|c|}
\hline Item & 1990 & 1991 & 1992 & 1993 & 1994 & 1995 & 1996 & 1997 & 1998 & 1999 \\
\hline & \multicolumn{10}{|c|}{ Balance sheet items as a percentage of average net consolidated assets } \\
\hline Interest-earning assets . & 87.82 & 88.04 & 88.33 & 88.50 & 86.55 & 86.47 & 86.80 & 86.58 & 86.26 & 86.55 \\
\hline Loans and leases, net & 60.53 & 59.55 & 57.30 & 56.25 & 56.07 & 58.37 & 59.89 & 58.69 & 58.33 & 59.36 \\
\hline Commercial and industrial & 18.50 & 17.33 & 15.78 & 14.88 & 14.51 & 15.20 & 15.60 & 15.78 & 16.38 & 17.09 \\
\hline U.S. addressees ......... & 15.99 & 15.00 & 13.54 & 12.72 & 12.35 & 12.87 & 13.07 & 13.18 & 13.62 & 14.43 \\
\hline Foreign addressees $\ldots$ & 2.51 & 2.33 & 2.24 & 2.16 & 2.16 & 2.33 & 2.53 & 2.60 & 2.75 & 2.66 \\
\hline Consumer ........... & 11.77 & 11.45 & 11.00 & 11.00 & 11.43 & 12.08 & 12.21 & 11.44 & 10.36 & 9.71 \\
\hline Credit card .......... & 3.78 & 3.88 & 3.80 & 3.88 & 4.21 & 4.69 & 4.87 & 4.55 & 3.96 & 3.51 \\
\hline Installment and other & 7.99 & 7.57 & 7.20 & 7.11 & 7.22 & 7.39 & 7.34 & 6.89 & 6.39 & 6.20 \\
\hline Real estate ........... & 23.86 & 24.87 & 24.87 & 24.80 & 24.43 & 25.01 & 25.06 & 25.02 & 24.87 & 25.44 \\
\hline In domestic offices & 23.10 & 24.11 & 24.18 & 24.18 & 23.80 & 24.36 & 24.43 & 24.41 & 24.30 & 24.87 \\
\hline Construction and land development & 4.00 & 3.41 & 2.64 & 1.99 & 1.65 & 1.59 & 1.63 & 1.73 & 1.86 & 2.18 \\
\hline Farmland $\ldots \ldots \ldots \ldots \ldots \ldots \ldots \ldots$ & .51 & .53 & .56 & .57 & .56 & .56 & .56 & .55 & .55 & .56 \\
\hline One- to four-family residential & 11.21 & 12.27 & 12.91 & 13.49 & 13.74 & 14.42 & 14.43 & 14.42 & 14.26 & 14.10 \\
\hline Home equity $\ldots \ldots \ldots \ldots \ldots$ & 1.67 & 1.95 & 2.09 & 2.07 & 1.91 & 1.88 & 1.85 & 1.94 & 1.89 & 1.76 \\
\hline Other $\ldots \ldots \ldots \ldots$ & 9.54 & 10.32 & 10.83 & 11.42 & 11.84 & 12.54 & 12.57 & 12.48 & 12.37 & 12.33 \\
\hline Multifamily residential & .62 & .66 & .75 & .79 & .79 & .81 & .85 & .83 & .82 & .88 \\
\hline Nonfarm nonresidential & 6.76 & 7.23 & 7.32 & 7.33 & 7.07 & 6.97 & 6.96 & 6.88 & 6.81 & 7.15 \\
\hline In foreign offices ......... & .76 & .76 & .69 & .62 & .63 & .65 & .63 & .61 & .57 & .57 \\
\hline Depository institutions & 1.60 & 1.42 & 1.24 & 1.08 & 1.42 & 1.88 & 2.29 & 1.89 & 1.88 & 1.94 \\
\hline Foreign governments .. & .78 & .75 & .73 & .67 & .41 & .30 & .26 & .18 & .15 & .16 \\
\hline Agricultural production ... & .96 & 1.01 & 1.02 & .99 & 1.00 & .96 & .92 & .90 & .89 & .83 \\
\hline Other loans ............... & 3.93 & 3.60 & 3.50 & 3.56 & 3.34 & 3.15 & 3.36 & 2.84 & 2.81 & 2.76 \\
\hline Lease-financing receivables .... & 1.12 & 1.09 & 1.03 & .99 & 1.03 & 1.19 & 1.51 & 1.87 & 2.14 & 2.53 \\
\hline LESS: Unearned income on loans & -.42 & -.36 & -.28 & -.21 & -.16 & -.14 & -.12 & -.09 & -.07 & -.06 \\
\hline LEss: Loss reserves ${ }^{1} \ldots \ldots \ldots \ldots$ & -1.57 & -1.62 & -1.60 & -1.51 & -1.36 & -1.26 & -1.21 & -1.13 & -1.07 & -1.04 \\
\hline Securities ............ & 19.09 & 20.70 & 23.52 & 25.37 & 24.27 & 21.94 & 21.01 & 20.41 & 20.38 & 20.39 \\
\hline Investment account & 17.63 & 18.93 & 21.18 & 22.50 & 21.60 & 19.39 & 18.20 & 17.25 & 17.49 & 18.33 \\
\hline Debt ............ & 17.37 & 18.62 & 20.82 & 22.12 & 21.21 & 18.98 & 17.75 & 16.75 & 16.94 & 17.73 \\
\hline U.S. Treasury $\ldots \ldots \ldots \ldots$ & 4.57 & 5.06 & 6.49 & 7.08 & 6.77 & 5.25 & 4.20 & 3.38 & 2.71 & 2.14 \\
\hline U.S. government agency and & & & & & & & & & & \\
\hline corporation obligations $\ldots \ldots \ldots$ & 7.56 & 8.75 & 9.86 & 10.73 & 10.24 & 9.81 & 9.75 & 9.74 & 10.29 & 10.85 \\
\hline Government-backed mortgage pools & 4.08 & 4.51 & 4.52 & 4.74 & 4.67 & 4.47 & 4.80 & 4.94 & 5.17 & 5.23 \\
\hline Collateralized mortgage obligations & 1.25 & 2.07 & 3.12 & 3.72 & 3.24 & 2.67 & 2.11 & 1.94 & 2.13 & 2.15 \\
\hline Other $\ldots \ldots \ldots \ldots \ldots \ldots \ldots \ldots \ldots$ & 2.22 & 2.16 & 2.21 & 2.27 & 2.33 & 2.68 & 2.83 & 2.86 & 2.99 & 3.46 \\
\hline State and local government ... & 2.64 & 2.28 & 2.08 & 2.06 & 2.02 & 1.80 & 1.68 & 1.59 & 1.57 & 1.62 \\
\hline Private mortgage-backed securities & n.a. & .94 & .82 & .73 & .64 & .62 & .61 & .50 & .67 & .88 \\
\hline Other $\ldots \ldots \ldots \ldots \ldots \ldots \ldots \ldots \ldots$ & 2.59 & 1.59 & 1.58 & 1.52 & 1.54 & 1.49 & 1.51 & 1.54 & 1.71 & 2.24 \\
\hline Equity $\ldots \ldots \ldots \ldots$ & .27 & .31 & .37 & .38 & .39 & .41 & .45 & .50 & .55 & .61 \\
\hline Trading account $\ldots \ldots \ldots \ldots \ldots \ldots \ldots \ldots$ & 1.46 & 1.77 & 2.34 & 2.87 & 2.67 & 2.55 & 2.81 & 3.16 & 2.90 & 2.06 \\
\hline Gross federal funds sold and reverse RPs & 4.46 & 4.58 & 4.54 & 4.27 & 3.82 & 3.93 & 3.82 & 5.18 & 5.37 & 4.61 \\
\hline Interest-bearing balances at depositories ... & 3.75 & 3.21 & 2.97 & 2.62 & 2.40 & 2.23 & 2.08 & 2.29 & 2.17 & 2.18 \\
\hline Non-interest-earning assets . . . . . . . . . . . . & 12.18 & 11.96 & 11.67 & 11.50 & 13.45 & 13.53 & 13.20 & 13.42 & 13.74 & 13.45 \\
\hline Revaluation gains on off-balance-sheet items ${ }^{2}$ & n.a. & n.a. & n.a. & n.a. & 2.61 & 2.90 & 2.25 & 2.59 & 2.95 & 2.57 \\
\hline Other $\ldots \ldots \ldots \ldots \ldots \ldots \ldots \ldots \ldots \ldots \ldots \ldots \ldots$ & 12.18 & 11.96 & 11.67 & 11.50 & 10.84 & 10.62 & 10.95 & 10.83 & 10.79 & 10.89 \\
\hline Liabilities ............... & 93.60 & 93.33 & 92.82 & 92.15 & 92.12 & 91.99 & 91.73 & 91.57 & 91.51 & 91.51 \\
\hline Interest-bearing liabilities & 76.53 & 76.58 & 75.32 & 73.92 & 71.86 & 71.86 & 71.62 & 71.36 & 71.33 & 72.52 \\
\hline Deposits ............. & 63.44 & 64.45 & 62.94 & 60.26 & 57.34 & 56.30 & 55.87 & 55.01 & 54.66 & 54.80 \\
\hline In foreign offices ... & 9.26 & 8.55 & 8.37 & 8.32 & 9.39 & 10.28 & 10.01 & 10.02 & 10.15 & 10.46 \\
\hline In domestic offices ........ & 54.18 & 55.90 & 54.56 & 51.94 & 47.96 & 46.03 & 45.86 & 44.99 & 44.51 & 44.34 \\
\hline Other checkable deposits ... & 6.19 & 6.72 & 7.65 & 8.24 & 7.80 & 6.63 & 4.75 & 3.62 & 3.11 & 2.81 \\
\hline Savings (including MMDAs) $\ldots . .$. & 16.59 & 18.00 & 20.28 & 20.91 & 19.60 & 17.48 & 18.71 & 19.13 & 19.91 & 21.00 \\
\hline Small-denomination time deposits. & 19.96 & 21.30 & 19.21 & 16.98 & 15.33 & 16.14 & 15.97 & 15.17 & 14.15 & 13.10 \\
\hline Large-denomination time deposits & 11.44 & 9.89 & 7.42 & 5.81 & 5.23 & 5.77 & 6.42 & 7.08 & 7.34 & 7.42 \\
\hline Gross federal funds purchased and RPs ... & 8.03 & 7.09 & 7.02 & 7.47 & 7.60 & 7.71 & 7.18 & 8.13 & 7.99 & 7.97 \\
\hline Other $\ldots \ldots \ldots \ldots \ldots \ldots \ldots \ldots \ldots \ldots \ldots \ldots \ldots$ & 5.07 & 5.03 & 5.36 & 6.19 & 6.92 & 7.85 & 8.56 & 8.21 & 8.68 & 9.75 \\
\hline Non-interest-bearing liabilities $\ldots \ldots \ldots \ldots \ldots \ldots$ & 17.07 & 16.75 & 17.50 & 18.23 & 20.26 & 20.13 & 20.11 & 20.21 & 20.18 & 18.99 \\
\hline Demand deposits in domestic offices .......... & 12.79 & 12.59 & 13.24 & 13.86 & 13.49 & 12.68 & 12.82 & 12.16 & 11.00 & 9.78 \\
\hline Revaluation losses on off-balance-sheet items ${ }^{2}$ & n.a. & n.a. & n.a. & n.a. & 2.32 & 2.88 & 2.14 & 2.64 & 2.97 & 2.52 \\
\hline 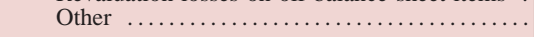 & 4.27 & 4.16 & 4.27 & 4.37 & 4.45 & 4.57 & 5.14 & 5.41 & 6.21 & 6.70 \\
\hline Capital account & 6.40 & 6.67 & 7.18 & 7.85 & 7.88 & 8.01 & 8.27 & 8.43 & 8.49 & 8.49 \\
\hline Мемо & & & & & & & & & & \\
\hline Commercial real estate loans & n.a. & 12.02 & 11.34 & 10.63 & 9.94 & 9.83 & 9.92 & 9.99 & 10.12 & 10.87 \\
\hline Other real estate owned ..... & .50 & .75 & .82 & .63 & .36 & .19 & .14 & .11 & .08 & .06 \\
\hline Managed liabilities ............. & 34.31 & 31.05 & 28.70 & 28.28 & 29.61 & 32.08 & 32.73 & 34.09 & 34.94 & 36.58 \\
\hline $\begin{array}{l}\text { Average net consolidated assets } \\
\text { (billions of dollars) } \ldots \ldots \ldots\end{array}$ & 3,338 & 3,379 & 3,442 & 3,566 & 3,863 & 4,148 & 4,376 & 4,733 & 5,144 & 5,438 \\
\hline
\end{tabular}




\section{A.2.-Continued}

A. All banks

\begin{tabular}{|c|c|c|c|c|c|c|c|c|c|c|}
\hline Item & 1990 & 1991 & 1992 & 1993 & 1994 & 1995 & 1996 & 1997 & 1998 & 1999 \\
\hline & \multicolumn{10}{|c|}{ Effective interest rate (percent) ${ }^{3}$} \\
\hline \multicolumn{11}{|l|}{ Rates earned } \\
\hline Interest-earning assets . & 10.67 & 9.57 & 8.27 & 7.61 & 7.61 & 8.33 & 8.14 & 8.15 & 7.99 & 7.73 \\
\hline Taxable equivalent .. & 10.80 & 9.69 & 8.37 & 7.71 & 7.70 & 8.41 & 8.21 & 8.22 & 8.06 & 7.79 \\
\hline Loans and leases, gross ... & 11.49 & 10.40 & 9.20 & 8.69 & 8.62 & 9.25 & 8.99 & 9.01 & 8.84 & 8.50 \\
\hline Net of loss provisions $\ldots \ldots \ldots \ldots \ldots$ & 9.94 & 8.72 & 7.87 & 7.87 & 8.12 & 8.74 & 8.39 & 8.34 & 8.15 & 7.86 \\
\hline Securities $\ldots \ldots \ldots \ldots \ldots \ldots \ldots \ldots \ldots \ldots \ldots \ldots \ldots \ldots$ & 8.79 & 8.19 & 7.04 & 6.08 & 5.96 & 6.51 & 6.42 & 6.50 & 6.37 & 6.28 \\
\hline Taxable equivalent & 9.21 & 8.56 & 7.34 & 6.36 & 6.20 & 6.73 & 6.66 & 6.73 & 6.63 & 6.48 \\
\hline Investment account $\ldots \ldots \ldots \ldots \ldots$ & 8.67 & 8.25 & 7.11 & 6.07 & 5.79 & 6.35 & 6.35 & 6.45 & 6.29 & 6.26 \\
\hline U.S. government and other debt & 8.92 & 8.43 & 7.18 & 6.07 & 5.80 & 6.42 & 6.47 & 6.60 & 6.45 & 6.42 \\
\hline State and local $\ldots \ldots \ldots \ldots \ldots$ & 7.39 & 7.25 & 6.81 & 6.25 & 5.87 & 5.82 & 5.55 & 5.41 & 5.23 & 5.13 \\
\hline Equity $\ldots \ldots \ldots$ & 7.34 & 6.20 & 5.32 & 4.79 & 4.79 & 5.51 & 5.23 & 5.15 & 4.92 & 4.87 \\
\hline Trading account $\ldots \ldots \ldots \ldots \ldots \ldots \ldots$ & 10.15 & 7.54 & 6.40 & 6.16 & 7.41 & 7.73 & 6.86 & 6.75 & 6.85 & 6.48 \\
\hline Gross federal funds sold and reverse RPs & 8.08 & 5.69 & 3.58 & 3.04 & 4.26 & 5.63 & 5.21 & 5.45 & 5.29 & 4.78 \\
\hline Interest-bearing balances at depositories . & 9.96 & 8.44 & 7.31 & 6.61 & 5.71 & 6.84 & 6.21 & 6.24 & 6.31 & 5.95 \\
\hline \multicolumn{11}{|l|}{ Rates paid } \\
\hline Interest-bearing liabilities . & 8.04 & 6.55 & 4.75 & 4.01 & 4.01 & 4.99 & 4.82 & 4.92 & 4.88 & 4.48 \\
\hline Interest-bearing deposits & 7.57 & 6.34 & 4.51 & 3.65 & 3.53 & 4.47 & 4.33 & 4.39 & 4.31 & 3.88 \\
\hline In foreign offices $\ldots .$. & 10.71 & 8.54 & 7.32 & 6.82 & 5.59 & 6.12 & 5.54 & 5.44 & 5.66 & 4.91 \\
\hline In domestic offices $\ldots \ldots \ldots$. & 7.02 & 6.00 & 4.07 & 3.14 & 3.14 & 4.11 & 4.07 & 4.16 & 4.01 & 3.65 \\
\hline Other checkable deposits & 4.79 & 4.34 & 2.70 & 1.99 & 1.85 & 2.06 & 2.03 & 2.25 & 2.29 & 2.08 \\
\hline Savings (including MMDAs) & 5.99 & 5.11 & 3.25 & 2.50 & 2.58 & 3.19 & 2.99 & 2.93 & 2.79 & 2.50 \\
\hline Large-denomination time deposits 4 & 8.03 & 6.69 & 4.90 & 4.00 & 4.09 & 5.47 & 5.39 & 5.45 & 5.22 & 4.93 \\
\hline Small-denomination time deposits 4 & 7.97 & 6.93 & 5.15 & 4.19 & 4.17 & 5.44 & 5.40 & 5.54 & 5.48 & 5.11 \\
\hline Gross federal funds purchased and RPs & 7.97 & 5.76 & 3.64 & 3.07 & 4.18 & 5.65 & 5.12 & 5.17 & 5.19 & 4.74 \\
\hline Other interest-bearing liabilities ......... & 12.26 & 8.65 & 7.87 & 8.02 & 7.25 & 7.47 & 6.93 & 6.95 & 6.89 & 6.49 \\
\hline & \multicolumn{10}{|c|}{ Income and expense as a percentage of average net consolidated assets } \\
\hline Gross interest income. & 9.60 & 8.60 & 7.45 & 6.86 & 6.65 & 7.29 & 7.16 & 7.15 & 6.98 & 6.75 \\
\hline Taxable equivalent & 9.71 & 8.70 & 7.54 & 6.94 & 6.73 & 7.35 & 7.21 & 7.20 & 7.03 & 6.80 \\
\hline Loans $\ldots \ldots \ldots \ldots \ldots$ & 7.15 & 6.36 & 5.40 & 5.00 & 4.91 & 5.48 & 5.47 & 5.40 & 5.27 & 5.14 \\
\hline Securities $\ldots \ldots \ldots \ldots \ldots \ldots \ldots \ldots \ldots$ & 1.53 & 1.56 & 1.51 & 1.37 & 1.25 & 1.23 & 1.16 & 1.11 & 1.10 & 1.15 \\
\hline Gross federal funds sold and reverse RPs & .38 & .27 & .17 & .13 & .17 & .23 & .21 & .29 & .29 & .23 \\
\hline Other $\ldots \ldots \ldots \ldots \ldots \ldots \ldots \ldots \ldots \ldots \ldots \ldots$ & .54 & .41 & .37 & .36 & .33 & .35 & .32 & .35 & .32 & .24 \\
\hline Gross interest expense & 6.14 & 4.99 & 3.56 & 2.96 & 2.87 & 3.57 & 3.43 & 3.48 & 3.46 & 3.22 \\
\hline Deposits $\ldots \ldots \ldots \ldots \ldots \ldots \ldots \ldots \ldots$ & 4.84 & 4.13 & 2.87 & 2.23 & 2.05 & 2.54 & 2.46 & 2.48 & 2.43 & 2.21 \\
\hline Gross federal funds purchased and RPs. & .68 & .43 & .27 & .24 & .32 & .44 & .38 & .43 & .43 & .39 \\
\hline Other $\ldots \ldots \ldots \ldots \ldots \ldots \ldots \ldots \ldots \ldots \ldots \ldots$ & .62 & .43 & .42 & .50 & .50 & .58 & .59 & .56 & .59 & .63 \\
\hline Net interest income .... & 3.46 & 3.62 & 3.89 & 3.90 & 3.78 & 3.72 & 3.73 & 3.67 & 3.52 & 3.53 \\
\hline Taxable equivalent & 3.57 & 3.71 & 3.98 & 3.98 & 3.86 & 3.79 & 3.78 & 3.72 & 3.57 & 3.58 \\
\hline Loss provisioning ${ }^{5}$ & .97 & 1.03 & .78 & .47 & .28 & .30 & .37 & .41 & .41 & .39 \\
\hline Noninterest income...$\ldots \ldots$ & 1.67 & 1.81 & 1.95 & 2.13 & 2.00 & 2.02 & 2.18 & 2.23 & 2.41 & 2.66 \\
\hline Service charges on deposits $\ldots$. & .34 & .38 & .41 & .42 & .40 & .39 & .39 & .39 & .38 & .40 \\
\hline Income from fiduciary activities ...... & .27 & .28 & .30 & .31 & .31 & .31 & .33 & .35 & .37 & .39 \\
\hline Trading income $\ldots \ldots \ldots \ldots \ldots \ldots \ldots$ & .15 & .18 & .18 & .26 & .16 & .15 & .17 & .17 & .16 & .19 \\
\hline Interest rate exposures $\ldots \ldots \ldots \ldots \ldots$ & n.a. & n.a. & n.a. & n.a. & n.a. & n.a. & .09 & .08 & .05 & .07 \\
\hline Foreign exchange exposures $\ldots \ldots \ldots \ldots \ldots$ & n.a. & n.a. & n.a. & n.a. & n.a. & n.a. & .06 & .08 & .10 & .09 \\
\hline Equity, commodity, and other exposures & n.a. & n.a. & n.a. & n.a. & n.a. & n.a. & .02 & * & .01 & .03 \\
\hline 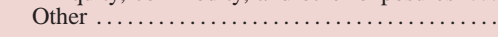 & .91 & .97 & 1.05 & 1.14 & 1.13 & 1.17 & 1.29 & 1.32 & 1.49 & 1.68 \\
\hline Noninterest expense $\ldots \ldots \ldots \ldots \ldots \ldots \ldots$ & 3.49 & 3.75 & 3.86 & 3.94 & 3.75 & 3.64 & 3.71 & 3.61 & 3.77 & 3.77 \\
\hline Salaries, wages, and employee benefits & 1.56 & 1.59 & 1.61 & 1.64 & 1.58 & 1.54 & 1.55 & 1.53 & 1.55 & 1.59 \\
\hline Expenses of premises and fixed assets & .53 & .53 & .53 & .52 & .49 & .48 & .48 & .47 & .47 & .48 \\
\hline Other $\ldots \ldots \ldots \ldots \ldots \ldots \ldots \ldots \ldots \ldots$ & 1.41 & 1.62 & 1.72 & 1.78 & 1.68 & 1.62 & 1.69 & 1.62 & 1.75 & 1.70 \\
\hline Net noninterest expense . & 1.83 & 1.94 & 1.91 & 1.81 & 1.75 & 1.62 & 1.53 & 1.38 & 1.36 & 1.11 \\
\hline Realized gains on investment account securities & .01 & .09 & .11 & .09 & -.01 & .01 & .03 & .04 & .06 & $*$ \\
\hline Income before taxes and extraordinary items ... & .68 & .73 & 1.32 & 1.70 & 1.73 & 1.81 & 1.85 & 1.93 & 1.81 & 2.04 \\
\hline 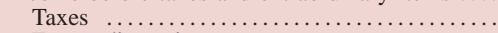 & .23 & .25 & .42 & .56 & .58 & .63 & .65 & .68 & .62 & .72 \\
\hline Extraordinary items $\ldots \ldots \ldots$ & .02 & .04 & .01 & .06 & $*$ & * & $*$ & $*$ & .01 & $*$ \\
\hline Net income (return on assets) & .47 & .52 & .91 & 1.20 & 1.15 & 1.18 & 1.20 & 1.25 & 1.20 & 1.31 \\
\hline Cash dividends declared ... & .42 & .46 & .41 & .62 & .73 & .75 & .90 & .90 & .80 & .96 \\
\hline Retained income ....... & .05 & .06 & .49 & .58 & .42 & .43 & .30 & .35 & .39 & .36 \\
\hline Memo: Return on equity & 7.31 & 7.80 & 12.64 & 15.32 & 14.63 & 14.69 & 14.52 & 14.84 & 14.07 & 15.48 \\
\hline
\end{tabular}

* In absolute value, less than 0.005 percent.

n.a. Not available. MMDA Money market deposit account. RP Repurchase agreement. CD Certificate of deposit.

1. Includes the allowance for loan and lease losses and the allocated transfer risk reserve.

2. Before 1994, the netted value of off-balance-sheet items appeared in "trading account securities"

if a gain and "other non-interest-bearing liabilities" if a loss.

3. When possible, based on the average of quarterly balance sheet data reported on schedule RC-K of the quarterly Call Reports.

4. Before 1997, data for large time open accounts are included in small-denomination time deposits.

5. Includes provisions for loan and lease losses and for allocated transfer risk. 
A.2. Portfolio composition, interest rates, and income and expense, all U.S. banks, 1990-99 B. Ten largest banks by assets

\begin{tabular}{|c|c|c|c|c|c|c|c|c|c|c|}
\hline Item & 1990 & 1991 & 1992 & 1993 & 1994 & 1995 & 1996 & 1997 & 1998 & 1999 \\
\hline & \multicolumn{10}{|c|}{ Balance sheet items as a percentage of average net consolidated assets } \\
\hline Interest-earning assets . & 84.85 & 85.41 & 85.16 & 84.79 & 76.97 & 77.02 & 79.94 & 81.62 & 81.07 & 81.29 \\
\hline Loans and leases, net $\ldots \ldots$ & 61.69 & 62.14 & 58.34 & 55.57 & 49.91 & 50.05 & 53.51 & 50.91 & 50.77 & 53.38 \\
\hline Commercial and industrial & 22.91 & 22.42 & 20.32 & 18.65 & 16.43 & 16.16 & 17.17 & 16.90 & 18.07 & 19.24 \\
\hline U.S. addressees ......... & 13.39 & 13.44 & 12.00 & 10.75 & 9.16 & 8.66 & 9.59 & 10.24 & 11.76 & 13.14 \\
\hline Foreign addressees ... & 9.53 & 8.97 & 8.32 & 7.90 & 7.27 & 7.50 & 7.59 & 6.66 & 6.31 & 6.10 \\
\hline Consumer ........... & 6.87 & 7.20 & 7.31 & 7.33 & 6.59 & 6.60 & 6.22 & 6.40 & 6.04 & 5.94 \\
\hline Credit card $\ldots \ldots \ldots \ldots$ & 2.20 & 2.53 & 2.61 & 2.50 & 2.28 & 1.96 & 1.23 & 1.34 & 1.30 & 1.36 \\
\hline Installment and other & 4.67 & 4.67 & 4.70 & 4.83 & 4.31 & 4.65 & 4.99 & 5.06 & 4.74 & 4.58 \\
\hline Real estate $\ldots \ldots \ldots \ldots$ & 20.56 & 21.68 & 19.93 & 18.54 & 16.21 & 15.82 & 16.53 & 17.42 & 16.51 & 16.96 \\
\hline In domestic offices $\ldots \ldots \ldots \ldots \ldots \ldots$ & 17.36 & 18.37 & 17.07 & 15.99 & 13.80 & 13.48 & 14.44 & 15.69 & 15.08 & 15.55 \\
\hline Construction and land development & 3.79 & 3.42 & 2.48 & 1.59 & .84 & .58 & .51 & .68 & .77 & .90 \\
\hline Farmland $\ldots \ldots \ldots \ldots \ldots \ldots \ldots$ & .08 & .08 & .07 & .07 & .06 & .06 & .06 & .09 & .09 & .10 \\
\hline One- to four-family residential & 9.31 & 10.34 & 10.08 & 10.29 & 9.69 & 9.62 & 10.43 & 11.02 & 10.33 & 10.77 \\
\hline Home equity $\ldots \ldots \ldots \ldots$ & 1.31 & 1.63 & 1.63 & 1.60 & 1.40 & 1.40 & 1.53 & 1.70 & 1.72 & 1.54 \\
\hline Other $\ldots \ldots \ldots \ldots$ & 8.00 & 8.71 & 8.46 & 8.68 & 8.29 & 8.22 & 8.90 & 9.31 & 8.61 & 9.22 \\
\hline Multifamily residential & .68 & .57 & .58 & .53 & .41 & .38 & .38 & .39 & .38 & .43 \\
\hline Nonfarm nonresidential & 3.51 & 3.95 & 3.86 & 3.51 & 2.79 & 2.83 & 3.05 & 3.52 & 3.51 & 3.35 \\
\hline In foreign offices $\ldots \ldots \ldots$ & 3.20 & 3.32 & 2.85 & 2.55 & 2.41 & 2.35 & 2.09 & 1.73 & 1.43 & 1.41 \\
\hline Depository institutions & 3.64 & 3.05 & 2.56 & 2.35 & 3.37 & 4.95 & 6.06 & 4.14 & 4.00 & 4.30 \\
\hline Foreign governments. & 2.76 & 2.88 & 2.75 & 2.46 & 1.27 & .90 & .69 & .45 & .35 & .38 \\
\hline Agricultural production & .31 & .31 & .28 & .27 & .25 & .21 & .23 & .31 & .28 & .26 \\
\hline Other loans ............. & 6.05 & 5.61 & 6.05 & 6.82 & 6.44 & 5.85 & 6.42 & 4.21 & 3.79 & 3.97 \\
\hline Lease-financing receivables $\ldots .$. & 1.60 & 1.68 & 1.51 & 1.30 & 1.14 & 1.14 & 1.59 & 2.24 & 2.81 & 3.41 \\
\hline LESS: Unearned income on loans & -.39 & -.35 & -.27 & -.21 & -.16 & -.14 & -.11 & -.07 & -.06 & -.05 \\
\hline LEss: Loss reserves ${ }^{1} \ldots \ldots \ldots$ & -2.63 & -2.34 & -2.08 & -1.94 & -1.63 & -1.45 & -1.30 & -1.08 & -1.01 & -1.03 \\
\hline Securities ............ & 14.03 & 15.58 & 19.13 & 22.74 & 20.43 & 19.53 & 19.83 & 20.00 & 19.72 & 18.34 \\
\hline Investment account & 9.22 & 9.38 & 10.70 & 12.45 & 11.68 & 10.65 & 10.60 & 10.97 & 12.12 & 13.08 \\
\hline Debt $\ldots \ldots \ldots \ldots$ & 8.98 & 9.08 & 10.36 & 12.08 & 11.30 & 10.27 & 10.22 & 10.55 & 11.65 & 12.57 \\
\hline U.S. Treasury $\ldots \ldots \ldots \ldots$ & 1.09 & 1.35 & 2.30 & 2.39 & 2.17 & 2.03 & 1.93 & 1.56 & 1.70 & 1.98 \\
\hline \multicolumn{11}{|l|}{ U.S. government agency and } \\
\hline corporation obligations $\ldots \ldots \ldots$ & 2.91 & 3.46 & 4.45 & 6.14 & 5.16 & 4.46 & 4.59 & 5.34 & 6.31 & 6.35 \\
\hline Government-backed mortgage pools & 2.24 & 2.26 & 2.43 & 3.30 & 2.79 & 2.89 & 3.58 & 4.26 & 5.13 & 5.03 \\
\hline Collateralized mortgage obligations . & .54 & 1.12 & 1.97 & 2.76 & 2.31 & 1.50 & .95 & .93 & .93 & .79 \\
\hline Other $\ldots \ldots \ldots \ldots \ldots \ldots \ldots$ & .14 & .08 & .05 & .08 & .06 & .08 & .06 & .15 & .26 & .52 \\
\hline State and local government ........ & 1.08 & .77 & .66 & .59 & .60 & .49 & .39 & .51 & .47 & .45 \\
\hline Private mortgage-backed securities & n.a. & .48 & .33 & .38 & .43 & .32 & .30 & .32 & .60 & .57 \\
\hline Other $\ldots \ldots \ldots \ldots \ldots \ldots \ldots \ldots$ & 3.90 & 3.01 & 2.62 & 2.59 & 2.94 & 2.97 & 3.01 & 2.81 & 2.57 & 3.22 \\
\hline Equity $\ldots . .$. & .24 & .30 & .33 & .36 & .38 & .38 & .38 & .42 & .47 & .51 \\
\hline Trading account $\ldots \ldots \ldots \ldots \ldots \ldots$ & 4.81 & 6.19 & 8.43 & 10.30 & 8.74 & 8.88 & 9.23 & 9.03 & 7.60 & 5.25 \\
\hline Gross federal funds sold and reverse RPs .. & 2.88 & 2.96 & 3.23 & 2.71 & 2.68 & 3.20 & 3.10 & 7.56 & 7.81 & 6.64 \\
\hline Interest-bearing balances at depositories .... & 6.25 & 4.74 & 4.45 & 3.76 & 3.95 & 4.25 & 3.50 & 3.15 & 2.77 & 2.94 \\
\hline Non-interest-earning assets $\ldots . . . \ldots \ldots \ldots \ldots$ & 15.15 & 14.59 & 14.84 & 15.21 & 23.03 & 22.98 & 20.06 & 18.38 & 18.93 & 18.71 \\
\hline Revaluation gains on off-balance-sheet items ${ }^{2}$ & n.a. & n.a. & n.a. & n.a. & 9.89 & 10.77 & 7.63 & 7.36 & 7.61 & 6.66 \\
\hline 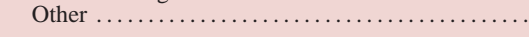 & 15.15 & 14.59 & 14.84 & 15.21 & 13.14 & 12.21 & 12.43 & 11.02 & 11.32 & 12.05 \\
\hline Liabilities $\ldots \ldots \ldots \ldots \ldots \ldots$ & 95.29 & 94.97 & 94.44 & 93.24 & 93.42 & 93.59 & 93.04 & 92.61 & 92.58 & 92.28 \\
\hline Interest-bearing liabilities . & 73.97 & 74.62 & 73.08 & 71.56 & 64.33 & 63.37 & 64.45 & 65.83 & 65.81 & 66.88 \\
\hline Deposits ............. & 57.95 & 57.67 & 55.73 & 52.91 & 48.20 & 47.49 & 47.87 & 47.36 & 47.65 & 48.80 \\
\hline In foreign offices ... & 29.66 & 28.47 & 27.16 & 25.51 & 26.10 & 28.36 & 26.41 & 22.18 & 20.17 & 21.04 \\
\hline In domestic offices $\ldots \ldots \ldots$ & 28.28 & 29.19 & 28.56 & 27.41 & 22.10 & 19.12 & 21.46 & 25.18 & 27.48 & 27.76 \\
\hline Other checkable deposits ... & 2.74 & 3.00 & 3.38 & 3.45 & 2.91 & 2.30 & 1.61 & 1.21 & .99 & .74 \\
\hline Savings (including MMDAs) ..... & 12.05 & 13.50 & 14.91 & 15.33 & 12.70 & 10.56 & 12.31 & 14.26 & 15.84 & 16.83 \\
\hline Small-denomination time deposits . & 6.16 & 6.55 & 5.72 & 5.09 & 3.98 & 4.04 & 4.68 & 5.82 & 6.03 & 5.66 \\
\hline Large-denomination time deposits & 7.33 & 6.14 & 4.56 & 3.53 & 2.51 & 2.23 & 2.86 & 3.89 & 4.62 & 4.53 \\
\hline Gross federal funds purchased and RPs ... & 6.90 & 6.80 & 6.19 & 6.70 & 5.83 & 6.17 & 5.88 & 10.26 & 9.79 & 8.84 \\
\hline Other $\ldots \ldots \ldots \ldots \ldots \ldots \ldots \ldots$ & 9.13 & 10.15 & 11.16 & 11.94 & 10.29 & 9.71 & 10.69 & 8.20 & 8.37 & 9.24 \\
\hline Non-interest-bearing liabilities $\ldots \ldots \ldots \ldots \ldots$ & 21.32 & 20.35 & 21.36 & 21.68 & 29.09 & 30.22 & 28.59 & 26.78 & 26.76 & 25.40 \\
\hline Demand deposits in domestic offices ............ & 10.93 & 10.36 & 11.05 & 11.27 & 10.15 & 8.88 & 9.73 & 8.98 & 8.46 & 7.82 \\
\hline Revaluation losses on off-balance-sheet items ${ }^{2}$ & n.a. & n.a. & n.a. & n.a. & 8.75 & 10.68 & 7.27 & 7.53 & 7.66 & 6.51 \\
\hline Other $\ldots \ldots \ldots \ldots \ldots \ldots \ldots \ldots \ldots \ldots \ldots \ldots$ & 10.39 & 9.99 & 10.30 & 10.41 & 10.20 & 10.66 & 11.59 & 10.27 & 10.64 & 11.07 \\
\hline Capital account & 4.71 & 5.03 & 5.56 & 6.76 & 6.58 & 6.41 & 6.96 & 7.39 & 7.42 & 7.72 \\
\hline \multicolumn{11}{|l|}{ Мемо } \\
\hline Commercial real estate loans & n.a. & 9.05 & 8.01 & 6.46 & 4.65 & 4.40 & 4.65 & 5.45 & 5.61 & 5.69 \\
\hline Other real estate owned ....... & .42 & .78 & 1.13 & 1.02 & .58 & .27 & .18 & .13 & .09 & .06 \\
\hline Managed liabilities ........... & 54.79 & 53.23 & 50.82 & 49.23 & 46.21 & 47.94 & 47.39 & 46.02 & 44.43 & 45.49 \\
\hline $\begin{array}{l}\text { Average net consolidated assets } \\
\text { (billions of dollars) } \ldots \ldots \ldots\end{array}$ & 725 & 717 & 775 & 818 & 949 & 1,051 & 1,189 & 1,514 & 1,820 & 1,935 \\
\hline
\end{tabular}




\section{A.2.-Continued}

B. Ten largest banks by assets

\begin{tabular}{|c|c|c|c|c|c|c|c|c|c|c|}
\hline Item & 1990 & 1991 & 1992 & 1993 & 1994 & 1995 & 1996 & 1997 & 1998 & 1999 \\
\hline & \multicolumn{10}{|c|}{ Effective interest rate (percent) ${ }^{3}$} \\
\hline \multicolumn{11}{|l|}{ Rates earned } \\
\hline Interest-earning assets . & 11.65 & 9.92 & 8.67 & 8.16 & 8.15 & 8.20 & 7.72 & 7.55 & 7.54 & 7.35 \\
\hline Taxable equivalent ... & 11.70 & 9.95 & 8.72 & 8.20 & 8.18 & 8.22 & 7.74 & 7.60 & 7.57 & 7.39 \\
\hline Loans and leases, gross ... & 12.29 & 10.46 & 9.36 & 9.07 & 8.89 & 8.84 & 8.32 & 8.25 & 8.21 & 7.99 \\
\hline Net of loss provisions $\ldots$ & 11.10 & 8.58 & 7.51 & 7.95 & 8.38 & 8.62 & 8.11 & 7.93 & 7.62 & 7.50 \\
\hline Securities $\ldots \ldots \ldots \ldots \ldots \ldots \ldots$ & 9.85 & 8.52 & 7.38 & 6.69 & 7.09 & 7.41 & 6.80 & 6.70 & 6.79 & 6.52 \\
\hline Taxable equivalent & 10.00 & 8.63 & 7.54 & 6.77 & 7.19 & 7.47 & 6.85 & 6.85 & 6.89 & 6.65 \\
\hline Investment account $\ldots \ldots \ldots \ldots \ldots$ & 9.34 & 8.99 & 7.96 & 6.90 & 6.57 & 7.06 & 6.71 & 6.61 & 6.71 & 6.50 \\
\hline U.S. government and other debt & 9.68 & 9.29 & 8.13 & 6.99 & 6.70 & 7.22 & 6.86 & 6.80 & 6.92 & 6.68 \\
\hline State and local $\ldots \ldots \ldots \ldots \ldots$ & 7.54 & 7.67 & 7.40 & 6.99 & 6.35 & 6.23 & 5.73 & 5.55 & 5.50 & 5.65 \\
\hline Equity...$\ldots \ldots$ & 5.82 & 4.22 & 4.04 & 3.72 & 3.27 & 4.03 & 3.84 & 3.47 & 2.98 & 2.93 \\
\hline Trading account $\ldots \ldots \ldots \ldots \ldots \ldots \ldots$ & 10.75 & 7.84 & 6.69 & 6.45 & 7.79 & 7.83 & 6.90 & 6.81 & 6.92 & 6.56 \\
\hline Gross federal funds sold and reverse RPs & 8.01 & 5.60 & 3.65 & 3.02 & 4.52 & 5.20 & 4.92 & 5.45 & 5.20 & 4.52 \\
\hline Interest-bearing balances at depositories . & 11.06 & 10.05 & 9.29 & 8.34 & 7.27 & 7.15 & 6.71 & 6.91 & 7.16 & 7.22 \\
\hline \multicolumn{11}{|l|}{ Rates paid } \\
\hline Interest-bearing liabilities . & 10.18 & 7.71 & 6.17 & 5.60 & 5.43 & 5.88 & 5.44 & 5.41 & 5.29 & 4.79 \\
\hline Interest-bearing deposits & 9.03 & 7.09 & 5.33 & 4.50 & 4.32 & 4.99 & 4.57 & 4.54 & 4.40 & 3.82 \\
\hline In foreign offices $\ldots .$. & 11.11 & 8.76 & 7.55 & 6.87 & 6.04 & 6.07 & 5.62 & 5.52 & 5.83 & 4.99 \\
\hline In domestic offices $\ldots \ldots \ldots$. & 6.81 & 5.47 & 3.25 & 2.36 & 2.35 & 3.42 & 3.32 & 3.69 & 3.39 & 3.04 \\
\hline Other checkable deposits & 4.35 & 3.93 & 1.97 & 1.28 & 1.10 & 1.29 & 1.32 & 1.97 & 1.67 & 1.44 \\
\hline Savings (including MMDAs) ...... & 6.21 & 5.09 & 2.95 & 2.14 & 2.35 & 3.11 & 2.76 & 2.68 & 2.45 & 2.11 \\
\hline Large-denomination time deposits 4 & 7.96 & 6.50 & 4.66 & 3.55 & 3.12 & 3.73 & 4.62 & 5.17 & 4.53 & 4.36 \\
\hline Small-denomination time deposits 4 & 7.76 & 6.09 & 3.81 & 3.01 & 2.80 & 5.08 & 4.58 & 5.45 & 5.21 & 4.95 \\
\hline Gross federal funds purchased and RPs & 7.75 & 5.98 & 4.04 & 3.26 & 4.05 & 5.22 & 4.93 & 5.02 & 5.18 & 4.53 \\
\hline Other interest-bearing liabilities $\ldots . \ldots .$. & 17.27 & 11.20 & 10.40 & 11.16 & 10.87 & 9.80 & 8.86 & 9.13 & 8.85 & 8.61 \\
\hline & \multicolumn{10}{|c|}{ Income and expense as a percentage of average net consolidated assets } \\
\hline Gross interest income. & 10.37 & 8.77 & 7.69 & 7.22 & 6.37 & 6.42 & 6.26 & 6.31 & 6.21 & 6.01 \\
\hline Taxable equivalent & 10.43 & 8.80 & 7.72 & 7.25 & 6.40 & 6.43 & 6.27 & 6.33 & 6.23 & 6.03 \\
\hline Loans ............ & 7.96 & 6.77 & 5.65 & 5.22 & 4.49 & 4.44 & 4.48 & 4.31 & 4.27 & 4.35 \\
\hline Securities $\ldots \ldots \ldots \ldots \ldots \ldots \ldots \ldots \ldots$ & .86 & .84 & .85 & .86 & .77 & .75 & .71 & .73 & .81 & .85 \\
\hline Gross federal funds sold and reverse RPs & .25 & .17 & .14 & .11 & .15 & .21 & .18 & .45 & .42 & .30 \\
\hline Other $\ldots \ldots \ldots \ldots \ldots \ldots \ldots \ldots \ldots \ldots \ldots \ldots$ & 1.30 & .98 & 1.05 & 1.04 & .97 & 1.00 & .88 & .82 & .70 & .51 \\
\hline Gross interest expense & 7.65 & 5.81 & 4.54 & 4.06 & 3.52 & 3.74 & 3.52 & 3.55 & 3.48 & 3.16 \\
\hline Deposits $\ldots \ldots \ldots \ldots \ldots \ldots \ldots \ldots \ldots$ & 5.41 & 4.23 & 3.09 & 2.48 & 2.15 & 2.43 & 2.26 & 2.26 & 2.20 & 1.97 \\
\hline Gross federal funds purchased and RPs & .64 & .43 & .28 & .24 & .24 & .35 & .31 & .54 & .54 & .40 \\
\hline Other $\ldots \ldots \ldots \ldots \ldots \ldots \ldots \ldots \ldots \ldots \ldots \ldots$ & 1.60 & 1.15 & 1.17 & 1.35 & 1.13 & .95 & .95 & .75 & .74 & .79 \\
\hline Net interest income .... & 2.72 & 2.96 & 3.15 & 3.16 & 2.86 & 2.68 & 2.73 & 2.76 & 2.73 & 2.84 \\
\hline Taxable equivalent & 2.77 & 2.99 & 3.18 & 3.19 & 2.88 & 2.70 & 2.75 & 2.79 & 2.75 & 2.86 \\
\hline Loss provisioning ${ }^{5}$ & .77 & 1.21 & 1.12 & .64 & .26 & .11 & .11 & .16 & .31 & .26 \\
\hline Noninterest income...$\ldots \ldots$ & 2.27 & 2.40 & 2.59 & 2.99 & 2.33 & 2.16 & 2.34 & 2.12 & 2.16 & 2.55 \\
\hline Service charges on deposits $\ldots$. & .23 & .26 & .30 & .30 & .26 & .25 & .28 & .32 & .33 & .37 \\
\hline Income from fiduciary activities ...... & .31 & .33 & .37 & .39 & .36 & .30 & .31 & .34 & .32 & .31 \\
\hline Trading income $\ldots \ldots \ldots \ldots \ldots \ldots \ldots$ & .52 & .64 & .66 & .91 & .53 & .46 & .52 & .43 & .34 & .46 \\
\hline Interest rate exposures $\ldots \ldots \ldots \ldots \ldots$ & n.a. & n.a. & n.a. & n.a. & n.a. & n.a. & .30 & .23 & .10 & .17 \\
\hline Foreign exchange exposures $\ldots \ldots \ldots \ldots \ldots$ & n.a. & n.a. & n.a. & n.a. & n.a. & n.a. & .17 & .20 & .22 & .19 \\
\hline Equity, commodity, and other exposures.... & n.a. & n.a. & n.a. & n.a. & n.a. & n.a. & .05 & * & .02 & .09 \\
\hline 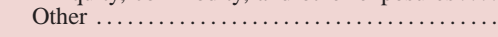 & 1.21 & 1.16 & 1.27 & 1.38 & 1.18 & 1.15 & 1.23 & 1.04 & 1.17 & 1.41 \\
\hline Noninterest expense $\ldots \ldots \ldots \ldots \ldots \ldots \ldots$ & 3.55 & 3.83 & 3.86 & 4.13 & 3.56 & 3.32 & 3.57 & 3.24 & 3.47 & 3.45 \\
\hline Salaries, wages, and employee benefits & 1.74 & 1.79 & 1.78 & 1.88 & 1.65 & 1.58 & 1.57 & 1.45 & 1.45 & 1.57 \\
\hline Expenses of premises and fixed assets & .65 & .66 & .65 & .66 & .55 & .50 & .50 & .47 & .47 & .50 \\
\hline Other $\ldots \ldots \ldots \ldots \ldots \ldots \ldots \ldots \ldots \ldots$ & 1.16 & 1.38 & 1.43 & 1.59 & 1.36 & 1.24 & 1.50 & 1.33 & 1.54 & 1.38 \\
\hline Net noninterest expense & 1.28 & 1.44 & 1.27 & 1.14 & 1.23 & 1.16 & 1.23 & 1.12 & 1.30 & .90 \\
\hline Realized gains on investment account securities & .02 & .04 & .11 & .13 & .02 & .03 & .04 & .08 & .11 & .03 \\
\hline Income before taxes and extraordinary items ... & 69 & .34 & .87 & 1.50 & 1.39 & 1.44 & 1.44 & 1.56 & 1.22 & 1.71 \\
\hline 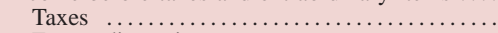 & .27 & .17 & .26 & .53 & .48 & .55 & .52 & .58 & .44 & .66 \\
\hline Extraordinary items $\ldots \ldots \ldots$ & .06 & .03 & $*$ & .16 & $*$ & $*$ & $*$ & $*$ & $*$ & $*$ \\
\hline Net income (return on assets) & .48 & .21 & .61 & 1.13 & .91 & .88 & .92 & .98 & .78 & 1.05 \\
\hline Cash dividends declared ... & .26 & .21 & .18 & .28 & .58 & .57 & .70 & .82 & .53 & .79 \\
\hline Retained income ....... & .21 & $*$ & .43 & .85 & .33 & .31 & .21 & .15 & .25 & .26 \\
\hline Memo: Return on equity & 10.13 & 4.23 & 10.91 & 16.75 & 13.86 & 13.78 & 13.21 & 13.22 & 10.53 & 13.58 \\
\hline
\end{tabular}

* In absolute value, less than 0.005 percent.

n.a. Not available. MMDA Money market deposit account. RP Repurchase agreement. CD Certificate of deposit.

1. Includes the allowance for loan and lease losses and the allocated transfer risk reserve.

2. Before 1994, the netted value of off-balance-sheet items appeared in "trading account securities"

if a gain and "other non-interest-bearing liabilities" if a loss.

3. When possible, based on the average of quarterly balance sheet data reported on schedule RC-K of the quarterly Call Reports.

4. Before 1997, data for large time open accounts are included in small-denomination time deposits.

5. Includes provisions for loan and lease losses and for allocated transfer risk. 
A.2. Portfolio composition, interest rates, and income and expense, all U.S. banks, 1990-99

C. Banks ranked 11 through 100 by assets

\begin{tabular}{|c|c|c|c|c|c|c|c|c|c|c|}
\hline Item & 1990 & 1991 & 1992 & 1993 & 1994 & 1995 & 1996 & 1997 & 1998 & 1999 \\
\hline & \multicolumn{10}{|c|}{ Balance sheet items as a percentage of average net consolidated assets } \\
\hline Interest-earning assets . & 86.81 & 86.88 & 87.97 & 88.36 & 88.16 & 88.31 & 87.75 & 86.95 & 87.39 & 87.94 \\
\hline Loans and leases, net & 61.22 & 60.08 & 58.30 & 57.33 & 58.56 & 62.68 & 64.24 & 63.89 & 64.42 & 64.29 \\
\hline Commercial and industrial & 21.76 & 20.53 & 18.83 & 18.03 & 18.03 & 19.26 & 18.95 & 19.01 & 18.92 & 19.41 \\
\hline U.S. addressees ......... & 20.44 & 19.30 & 17.78 & 17.05 & 16.99 & 18.10 & 17.71 & 17.78 & 17.59 & 18.19 \\
\hline Foreign addressees & 1.33 & 1.24 & 1.05 & .98 & 1.04 & 1.16 & 1.24 & 1.22 & 1.33 & 1.22 \\
\hline Consumer...$\ldots \ldots \ldots$ & 12.25 & 11.66 & 11.72 & 11.47 & 12.62 & 14.23 & 15.67 & 15.62 & 14.53 & 13.58 \\
\hline Credit card ......... & 5.48 & 5.04 & 5.16 & 5.23 & 5.99 & 7.34 & 8.26 & 8.50 & 7.67 & 6.79 \\
\hline Installment and other & 6.76 & 6.62 & 6.56 & 6.24 & 6.63 & 6.89 & 7.40 & 7.12 & 6.86 & 6.79 \\
\hline Real estate ........... & 20.21 & 21.51 & 21.89 & 22.11 & 22.26 & 23.25 & 23.26 & 22.99 & 24.60 & 24.81 \\
\hline In domestic offices & 20.04 & 21.37 & 21.78 & 22.01 & 22.17 & 23.10 & 23.10 & 22.85 & 24.42 & 24.63 \\
\hline Construction and land development & 4.91 & 4.00 & 3.02 & 2.08 & 1.63 & 1.50 & 1.55 & 1.69 & 2.03 & 2.43 \\
\hline Farmland $\ldots \ldots \ldots \ldots \ldots \ldots \ldots \ldots$ & .12 & .12 & .14 & .13 & .14 & .13 & .13 & .14 & .17 & .19 \\
\hline One- to four-family residential & 8.53 & 10.17 & 11.36 & 12.30 & 12.98 & 14.16 & 14.15 & 13.88 & 14.86 & 14.16 \\
\hline Home equity $\ldots \ldots \ldots \ldots \ldots$ & 1.67 & 2.07 & 2.50 & 2.54 & 2.33 & 2.19 & 2.08 & 2.22 & 2.17 & 2.08 \\
\hline Other ........ & 6.86 & 8.10 & 8.85 & 9.76 & 10.65 & 11.97 & 12.07 & 11.65 & 12.69 & 12.07 \\
\hline Multifamily residential & .46 & .54 & .66 & .71 & .71 & .77 & .89 & .93 & 1.00 & 1.02 \\
\hline Nonfarm nonresidential & 6.01 & 6.53 & 6.61 & 6.79 & 6.72 & 6.54 & 6.37 & 6.21 & 6.36 & 6.82 \\
\hline In foreign offices ......... & .18 & .14 & .11 & .10 & .09 & .15 & .16 & .15 & .18 & .19 \\
\hline Depository institutions & 1.57 & 1.58 & 1.43 & 1.30 & 1.49 & 1.59 & 1.50 & 1.27 & 1.06 & .92 \\
\hline Foreign governments. & .52 & .39 & .33 & .30 & .28 & .20 & .20 & .09 & .06 & .06 \\
\hline Agricultural production & .28 & .31 & .31 & .29 & .29 & .26 & .28 & .29 & .33 & .33 \\
\hline Other loans ............... & 4.82 & 4.55 & 4.28 & 4.05 & 3.47 & 3.32 & 3.30 & 3.21 & 3.38 & 3.01 \\
\hline Lease-financing receivables .. & 1.67 & 1.53 & 1.49 & 1.47 & 1.60 & 1.96 & 2.41 & 2.70 & 2.75 & 3.32 \\
\hline LEss: Unearned income on loans & -.26 & -.22 & -.17 & -.11 & -.07 & -.07 & -.06 & -.05 & -.04 & -.04 \\
\hline Less: Loss reserves ${ }^{1} \ldots \ldots \ldots \ldots$ & -1.60 & -1.76 & -1.79 & -1.60 & -1.41 & -1.32 & -1.27 & -1.24 & -1.16 & -1.11 \\
\hline Securities ............. & 16.19 & 17.38 & 20.38 & 21.97 & 21.19 & 18.64 & 16.87 & 15.80 & 16.67 & 17.78 \\
\hline Investment account & 15.32 & 16.25 & 19.24 & 20.60 & 19.82 & 17.88 & 16.06 & 15.07 & 16.13 & 17.26 \\
\hline Debt $\ldots \ldots \ldots \ldots$ & 15.14 & 16.02 & 18.99 & 20.34 & 19.50 & 17.51 & 15.62 & 14.58 & 15.58 & 16.62 \\
\hline U.S. Treasury $\ldots \ldots \ldots \ldots$ & 3.42 & 3.78 & 5.88 & 7.05 & 6.85 & 4.82 & 3.34 & 2.81 & 2.25 & 1.70 \\
\hline \multicolumn{11}{|l|}{ U.S. government agency and } \\
\hline corporation obligations $\ldots \ldots \ldots$ & 7.42 & 8.43 & 9.26 & 9.55 & 9.28 & 9.40 & 9.12 & 8.98 & 9.93 & 10.56 \\
\hline Government-backed mortgage pools & 5.32 & 5.38 & 5.22 & 5.21 & 5.30 & 5.06 & 5.42 & 5.17 & 4.98 & 5.12 \\
\hline Collateralized mortgage obligations .... & 1.56 & 2.48 & 3.54 & 3.71 & 3.07 & 2.82 & 2.16 & 2.13 & 2.83 & 2.87 \\
\hline 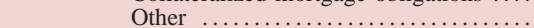 & .54 & .57 & .50 & .63 & .91 & 1.51 & 1.54 & 1.68 & 2.12 & 2.56 \\
\hline 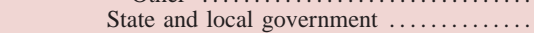 & 2.03 & 1.63 & 1.46 & 1.31 & 1.21 & 1.11 & .99 & .88 & .92 & .99 \\
\hline Private mortgage-backed securities ... & n.a. & 1.09 & 1.05 & 1.06 & .93 & 1.02 & .96 & .73 & .96 & 1.34 \\
\hline Other $\ldots \ldots \ldots \ldots \ldots \ldots \ldots \ldots \ldots \ldots$ & 2.27 & 1.10 & 1.34 & 1.37 & 1.22 & 1.16 & 1.21 & 1.18 & 1.53 & 2.03 \\
\hline Equity ....... & .18 & .22 & .25 & .26 & .32 & .37 & .44 & .49 & .55 & .65 \\
\hline Trading account $\ldots \ldots \ldots \ldots \ldots \ldots$ & .88 & 1.13 & 1.14 & 1.37 & 1.37 & .76 & .80 & .73 & .54 & .51 \\
\hline Gross federal funds sold and reverse RPs & 4.41 & 4.90 & 4.78 & 4.98 & 5.11 & 4.52 & 4.26 & 4.38 & 3.57 & 3.34 \\
\hline Interest-bearing balances at depositories ..... & 4.98 & 4.51 & 4.52 & 4.08 & 3.30 & 2.47 & 2.38 & 2.88 & 2.72 & 2.54 \\
\hline Non-interest-earning assets $\ldots \ldots \ldots \ldots \ldots \ldots \ldots$ & 13.19 & 13.12 & 12.03 & 11.64 & 11.84 & 11.69 & 12.25 & 13.05 & 12.61 & 12.06 \\
\hline Revaluation gains on off-balance-sheet items $^{2}$ & n.a. & n.a. & n.a. & n.a. & .57 & .50 & .51 & .69 & .75 & .57 \\
\hline 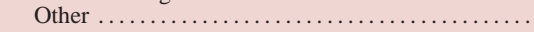 & 13.19 & 13.12 & 12.03 & 11.64 & 11.28 & 11.18 & 11.75 & 12.36 & 11.86 & 11.49 \\
\hline Liabilities $\ldots \ldots \ldots \ldots \ldots \ldots$. & 94.35 & 93.93 & 93.13 & 92.56 & 92.47 & 92.23 & 92.02 & 91.85 & 91.63 & 91.65 \\
\hline Interest-bearing liabilities & 77.02 & 76.07 & 74.66 & 73.38 & 72.86 & 74.05 & 73.14 & 72.62 & 73.40 & 74.95 \\
\hline 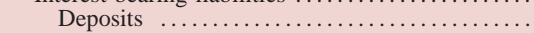 & 57.46 & 59.24 & 56.99 & 54.22 & 53.03 & 52.32 & 51.81 & 51.47 & 51.51 & 51.51 \\
\hline In foreign offices ... & 7.84 & 6.69 & 6.20 & 6.78 & 8.05 & 8.12 & 7.52 & 7.85 & 8.15 & 7.97 \\
\hline In domestic offices $\ldots . . . .$. & 49.62 & 52.54 & 50.79 & 47.43 & 44.98 & 44.20 & 44.30 & 43.62 & 43.36 & 43.54 \\
\hline Other checkable deposits ..... & 4.75 & 5.36 & 6.26 & 7.21 & 6.91 & 5.62 & 3.06 & 1.95 & 1.75 & 1.60 \\
\hline Savings (including MMDAs) .... & 15.50 & 17.62 & 20.21 & 20.60 & 20.13 & 18.78 & 20.76 & 21.09 & 21.41 & 22.46 \\
\hline Small-denomination time deposits & 15.59 & 17.99 & 15.98 & 14.19 & 13.26 & 14.24 & 14.09 & 13.43 & 12.84 & 11.85 \\
\hline Large-denomination time deposits & 13.78 & 11.56 & 8.34 & 5.44 & 4.68 & 5.55 & 6.39 & 7.15 & 7.36 & 7.62 \\
\hline Gross federal funds purchased and RPs . & 13.03 & 10.94 & 11.45 & 11.93 & 11.48 & 11.37 & 10.00 & 9.36 & 9.48 & 9.78 \\
\hline 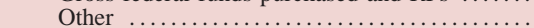 & 6.53 & 5.89 & 6.22 & 7.23 & 8.34 & 10.36 & 11.32 & 11.79 & 12.41 & 13.66 \\
\hline Non-interest-bearing liabilities $\ldots \ldots \ldots$ & 17.33 & 17.87 & 18.47 & 19.18 & 19.62 & 18.18 & 18.89 & 19.22 & 18.23 & 16.71 \\
\hline Demand deposits in domestic offices .......... & 13.23 & 13.76 & 14.52 & 15.38 & 15.27 & 14.26 & 14.47 & 14.17 & 12.40 & 10.52 \\
\hline Revaluation losses on off-balance-sheet items ${ }^{2}$ & n.a. & n.a. & n.a. & n.a. & .53 & .49 & .49 & .68 & .76 & .58 \\
\hline 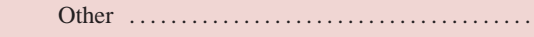 & 4.10 & 4.10 & 3.95 & 3.80 & 3.82 & 3.43 & 3.93 & 4.37 & 5.07 & 5.60 \\
\hline Capital account & 5.65 & 6.07 & 6.87 & 7.44 & 7.53 & 7.77 & 7.98 & 8.15 & 8.37 & 8.35 \\
\hline \multicolumn{11}{|l|}{ Мемо } \\
\hline Commercial real estate loans & n.a. & 11.83 & 11.09 & 10.29 & 9.69 & 9.42 & 9.38 & 9.44 & 10.11 & 11.00 \\
\hline Other real estate owned ..... & .46 & .76 & .70 & .47 & .25 & .13 & .08 & .06 & .04 & .03 \\
\hline Managed liabilities $\ldots \ldots \ldots \ldots . . . .$. & 41.59 & 35.49 & 32.59 & 31.76 & 32.89 & 35.68 & 35.60 & 36.60 & 38.09 & 39.81 \\
\hline $\begin{array}{l}\text { Average net consolidated assets } \\
\text { (billions of dollars) } \ldots \ldots \ldots . .\end{array}$ & 995 & 1,006 & 1,003 & 1,082 & 1,204 & 1,338 & 1,450 & 1,604 & 1,745 & 1,877 \\
\hline
\end{tabular}




\section{A.2.-Continued}

C. Banks ranked 11 through 100 by assets

\begin{tabular}{|c|c|c|c|c|c|c|c|c|c|c|}
\hline Item & 1990 & 1991 & 1992 & 1993 & 1994 & 1995 & 1996 & 1997 & 1998 & 1999 \\
\hline & \multicolumn{10}{|c|}{ Effective interest rate (percent) ${ }^{3}$} \\
\hline \multicolumn{11}{|l|}{ Rates earned } \\
\hline Interest-earning assets . & 10.46 & 9.30 & 7.97 & 7.35 & 7.29 & 8.31 & 8.16 & 8.31 & 8.10 & 7.91 \\
\hline Taxable equivalent .. & 10.55 & 9.39 & 8.07 & 7.45 & 7.37 & 8.37 & 8.23 & 8.36 & 8.17 & 7.94 \\
\hline Loans and leases, gross ... & 11.09 & 9.96 & 8.75 & 8.25 & 8.22 & 9.10 & 8.87 & 9.03 & 8.82 & 8.56 \\
\hline Net of loss provisions $\ldots$ & 9.08 & 7.98 & 7.45 & 7.46 & 7.68 & 8.49 & 8.05 & 8.11 & 8.01 & 7.73 \\
\hline Securities $\ldots \ldots \ldots \ldots \ldots \ldots \ldots$ & 8.86 & 8.23 & 7.00 & 6.05 & 5.70 & 6.38 & 6.42 & 6.50 & 6.21 & 6.45 \\
\hline Taxable equivalent & 9.18 & 8.57 & 7.30 & 6.32 & 5.92 & 6.56 & 6.66 & 6.70 & 6.46 & 6.55 \\
\hline Investment account $\ldots \ldots \ldots \ldots \ldots$ & 8.92 & 8.37 & 7.12 & 6.14 & 5.70 & 6.34 & 6.41 & 6.52 & 6.22 & 6.47 \\
\hline U.S. government and other debt & 9.18 & 8.51 & 7.16 & 6.14 & 5.69 & 6.38 & 6.50 & 6.63 & 6.31 & 6.59 \\
\hline State and local $\ldots \ldots \ldots \ldots \ldots$ & 7.32 & 7.23 & 6.80 & 6.30 & 6.04 & 6.05 & 5.84 & 5.58 & 5.36 & 5.28 \\
\hline Equity...$\ldots \ldots$ & 8.09 & 7.36 & 6.71 & 5.20 & 5.00 & 5.68 & 4.84 & 5.07 & 5.26 & 5.39 \\
\hline Trading account $\ldots \ldots \ldots \ldots \ldots \ldots \ldots$ & 8.01 & 6.46 & 4.73 & 4.74 & 5.75 & 7.27 & 6.53 & 6.05 & 5.86 & 5.63 \\
\hline Gross federal funds sold and reverse RPs & 8.15 & 5.80 & 3.70 & 3.11 & 4.31 & 5.91 & 5.31 & 5.45 & 5.46 & 5.13 \\
\hline Interest-bearing balances at depositories ... & 9.72 & 8.15 & 6.76 & 6.50 & 4.69 & 6.78 & 5.82 & 5.77 & 5.67 & 4.81 \\
\hline \multicolumn{11}{|l|}{ Rates paid } \\
\hline Interest-bearing liabilities . & 7.96 & 6.41 & 4.43 & 3.76 & 3.72 & 4.94 & 4.70 & 4.79 & 4.76 & 4.42 \\
\hline Interest-bearing deposits & 7.55 & 6.27 & 4.30 & 3.51 & 3.25 & 4.35 & 4.15 & 4.22 & 4.15 & 3.80 \\
\hline In foreign offices $\ldots .$. & 10.08 & 8.39 & 7.26 & 7.37 & 4.60 & 6.30 & 5.29 & 5.23 & 5.22 & 4.71 \\
\hline In domestic offices $\ldots \ldots \ldots$. & 7.15 & 6.01 & 3.96 & 2.98 & 3.03 & 4.01 & 3.96 & 4.04 & 3.96 & 3.64 \\
\hline Other checkable deposits & 4.67 & 4.21 & 2.43 & 1.70 & 1.62 & 1.89 & 1.78 & 2.01 & 2.41 & 2.06 \\
\hline Savings (including MMDAs) & 6.07 & 5.04 & 3.07 & 2.33 & 2.46 & 3.10 & 2.91 & 2.84 & 2.76 & 2.51 \\
\hline Large-denomination time deposits 4 & 8.11 & 6.77 & 5.10 & 4.30 & 4.21 & 5.70 & 5.50 & 5.47 & 5.32 & 5.01 \\
\hline Small-denomination time deposits 4 & 8.09 & 6.96 & 5.07 & 4.06 & 4.18 & 5.35 & 5.26 & 5.43 & 5.35 & 5.09 \\
\hline Gross federal funds purchased and RPs ...... & 8.12 & 5.75 & 3.57 & 3.04 & 4.28 & 5.86 & 5.19 & 5.29 & 5.22 & 4.91 \\
\hline \multirow[t]{2}{*}{ Other interest-bearing liabilities .............. } & 9.27 & 6.55 & 5.77 & 5.97 & 5.24 & 6.43 & 5.95 & 5.85 & 5.81 & 5.44 \\
\hline & \multicolumn{10}{|c|}{ Income and expense as a percentage of average net consolidated assets } \\
\hline Gross interest income. & 9.31 & 8.24 & 7.12 & 6.58 & 6.46 & 7.40 & 7.24 & 7.26 & 7.16 & 7.05 \\
\hline Taxable equivalent & 9.39 & 8.31 & 7.19 & 6.64 & 6.51 & 7.45 & 7.28 & 7.30 & 7.20 & 7.09 \\
\hline Loans $\ldots \ldots \ldots \ldots \ldots$ & 7.01 & 6.15 & 5.23 & 4.84 & 4.91 & 5.79 & 5.80 & 5.87 & 5.79 & 5.61 \\
\hline Securities $\ldots \ldots \ldots \ldots \ldots \ldots \ldots \ldots \ldots$ & 1.37 & 1.36 & 1.37 & 1.26 & 1.13 & 1.13 & 1.03 & .98 & 1.00 & 1.12 \\
\hline Gross federal funds sold and reverse RPs & .38 & .28 & .18 & .15 & .21 & .27 & .23 & .22 & .19 & .18 \\
\hline Other $\ldots \ldots \ldots \ldots \ldots \ldots \ldots \ldots \ldots \ldots \ldots \ldots$ & .56 & .45 & .34 & .32 & .21 & .21 & .18 & .19 & .18 & .14 \\
\hline Gross interest expense & 6.08 & 4.80 & 3.26 & 2.74 & 2.67 & 3.62 & 3.39 & 3.41 & 3.45 & 3.29 \\
\hline Deposits $\ldots \ldots \ldots \ldots \ldots \ldots \ldots \ldots \ldots$ & 4.36 & 3.75 & 2.48 & 1.93 & 1.73 & 2.29 & 2.18 & 2.23 & 2.23 & 2.04 \\
\hline Gross federal funds purchased and RPs. & 1.12 & .67 & .43 & .38 & .51 & .67 & .55 & .51 & .51 & .51 \\
\hline Other $\ldots \ldots \ldots \ldots \ldots \ldots \ldots \ldots \ldots \ldots \ldots \ldots$ & .60 & .38 & .35 & .43 & .43 & .66 & .66 & .68 & .71 & .74 \\
\hline Net interest income .... & 3.23 & 3.43 & 3.86 & 3.84 & 3.79 & 3.78 & 3.84 & 3.85 & 3.71 & 3.76 \\
\hline Taxable equivalent & 3.31 & 3.51 & 3.93 & 3.91 & 3.85 & 3.84 & 3.89 & 3.89 & 3.75 & 3.79 \\
\hline Loss provisioning ${ }^{5}$ & 1.27 & 1.22 & .78 & .47 & .32 & .39 & .54 & .60 & .53 & .54 \\
\hline Noninterest income...$\ldots \ldots$ & 1.84 & 2.05 & 2.25 & 2.29 & 2.25 & 2.38 & 2.61 & 2.76 & 3.07 & 3.37 \\
\hline Service charges on deposits $\ldots$. & .34 & .41 & .44 & .46 & .45 & .44 & .44 & .44 & .42 & .42 \\
\hline Income from fiduciary activities ...... & .33 & .36 & .38 & .38 & .39 & .40 & .43 & .44 & .49 & .52 \\
\hline Trading income $\ldots \ldots \ldots \ldots \ldots \ldots \ldots$ & .08 & .10 & .09 & .14 & .08 & .09 & .08 & .08 & .09 & .08 \\
\hline Interest rate exposures $\ldots \ldots \ldots \ldots \ldots$ & n.a. & n.a. & n.a. & n.a. & n.a. & n.a. & .03 & .02 & .03 & .02 \\
\hline Foreign exchange exposures $\ldots \ldots \ldots \ldots \ldots$ & n.a. & n.a. & n.a. & n.a. & n.a. & n.a. & .04 & .05 & .06 & .06 \\
\hline Equity, commodity, and other exposures .... & n.a. & n.a. & n.a. & n.a. & n.a. & n.a. & .01 & $*$ & $*$ & * \\
\hline 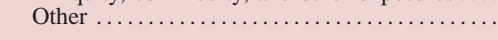 & 1.09 & 1.19 & 1.33 & 1.32 & 1.33 & 1.45 & 1.67 & 1.79 & 2.07 & 2.36 \\
\hline Noninterest expense $\ldots \ldots \ldots \ldots \ldots \ldots \ldots$ & 3.44 & 3.77 & 3.98 & 3.95 & 3.86 & 3.79 & 3.85 & 3.85 & 4.03 & 4.15 \\
\hline Salaries, wages, and employee benefits & 1.47 & 1.52 & 1.53 & 1.52 & 1.50 & 1.47 & 1.51 & 1.51 & 1.53 & 1.54 \\
\hline Expenses of premises and fixed assets & .50 & .51 & .49 & .47 & .47 & .47 & .48 & .46 & .46 & .46 \\
\hline Other $\ldots \ldots \ldots \ldots \ldots \ldots \ldots \ldots \ldots \ldots \ldots \ldots$ & 1.48 & 1.74 & 1.95 & 1.95 & 1.89 & 1.85 & 1.86 & 1.88 & 2.04 & 2.15 \\
\hline Net noninterest expense . & 1.60 & 1.73 & 1.73 & 1.65 & 1.61 & 1.41 & 1.24 & 1.10 & .96 & .78 \\
\hline Realized gains on investment account securities & .03 & .14 & .15 & .09 & -.01 & .02 & .02 & .02 & .03 & -.01 \\
\hline Income before taxes and extraordinary items ... & .38 & .62 & 1.50 & 1.81 & 1.85 & 2.01 & 2.09 & 2.18 & 2.24 & 2.43 \\
\hline 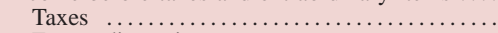 & .15 & .19 & .48 & .56 & .63 & .70 & .75 & .77 & .79 & .87 \\
\hline Extraordinary items $\ldots \ldots \ldots$ & .01 & .03 & .03 & $*$ & $*$ & * & $*$ & $*$ & $*$ & $*$ \\
\hline Net income (return on assets) & .24 & .47 & 1.04 & 1.25 & 1.22 & 1.31 & 1.34 & 1.42 & 1.46 & 1.56 \\
\hline Cash dividends declared ... & .38 & .47 & .46 & .76 & .86 & .85 & 1.07 & .93 & .96 & 1.17 \\
\hline Retained income ....... & -.14 & $*$ & .58 & .49 & .36 & .46 & .26 & .48 & .50 & .38 \\
\hline Memo: Return on equity & 4.18 & 7.71 & 15.16 & 16.86 & 16.27 & 16.84 & 16.78 & 17.36 & 17.38 & 18.63 \\
\hline
\end{tabular}

* In absolute value, less than 0.005 percent.

n.a. Not available. MMDA Money market deposit account. RP Repurchase agreement. CD Certificate of deposit.

1. Includes the allowance for loan and lease losses and the allocated transfer risk reserve.

2. Before 1994, the netted value of off-balance-sheet items appeared in "trading account securities"

if a gain and "other non-interest-bearing liabilities" if a loss.

3. When possible, based on the average of quarterly balance sheet data reported on schedule RC-K of the quarterly Call Reports.

4. Before 1997, data for large time open accounts are included in small-denomination time deposits.

5. Includes provisions for loan and lease losses and for allocated transfer risk. 
A.2. Portfolio composition, interest rates, and income and expense, all U.S. banks, 1990-99 D. Banks ranked 101 through 1,000 by assets

\begin{tabular}{|c|c|c|c|c|c|c|c|c|c|c|}
\hline Item & 1990 & 1991 & 1992 & 1993 & 1994 & 1995 & 1996 & 1997 & 1998 & 1999 \\
\hline & \multicolumn{10}{|c|}{ Balance sheet items as a percentage of average net consolidated assets } \\
\hline Interest-earning assets . & 88.84 & 88.91 & 89.02 & 89.55 & 90.09 & 90.12 & 90.13 & 90.31 & 90.39 & 90.75 \\
\hline Loans and leases, net & 63.09 & 61.03 & 58.49 & 57.94 & 59.75 & 62.18 & 62.63 & 62.21 & 61.12 & 61.50 \\
\hline Commercial and industrial & 16.69 & 15.04 & 13.34 & 12.19 & 12.07 & 12.70 & 12.79 & 12.43 & 12.49 & 12.65 \\
\hline U.S. addressees..$\ldots \ldots$ & 16.56 & 14.88 & 13.16 & 12.03 & 11.90 & 12.54 & 12.61 & 12.20 & 12.16 & 12.33 \\
\hline Foreign addressees $\ldots$ & .13 & .16 & .18 & .16 & .16 & .16 & .18 & .23 & .32 & .32 \\
\hline Consumer ........... & 15.48 & 15.13 & 14.18 & 14.83 & 15.85 & 16.25 & 15.88 & 13.99 & 12.28 & 10.79 \\
\hline Credit card .......... & 5.22 & 5.74 & 5.37 & 5.63 & 6.06 & 6.30 & 6.66 & 5.48 & 4.48 & 3.37 \\
\hline Installment and other & 10.26 & 9.39 & 8.80 & 9.20 & 9.79 & 9.95 & 9.22 & 8.51 & 7.80 & 7.42 \\
\hline Real estate ........... & 27.01 & 27.51 & 28.11 & 28.61 & 29.42 & 30.82 & 31.37 & 33.26 & 33.94 & 35.88 \\
\hline In domestic offices $\ldots \ldots \ldots \ldots \ldots$ & 26.99 & 27.47 & 28.07 & 28.59 & 29.39 & 30.80 & 31.35 & 33.23 & 33.91 & 35.86 \\
\hline Construction and land development & 4.37 & 3.66 & 2.86 & 2.26 & 2.08 & 2.21 & 2.38 & 2.69 & 2.88 & 3.49 \\
\hline Farmland $\ldots \ldots \ldots \ldots \ldots \ldots \ldots \ldots$ & .28 & .28 & .32 & .34 & .36 & .40 & .46 & .53 & .56 & .58 \\
\hline One- to four-family residential & 12.49 & 13.22 & 14.26 & 15.17 & 16.24 & 17.49 & 17.34 & 18.16 & 18.18 & 18.23 \\
\hline Home equity $\ldots \ldots \ldots \ldots \ldots$ & 2.31 & 2.53 & 2.56 & 2.50 & 2.33 & 2.36 & 2.31 & 2.30 & 2.14 & 1.99 \\
\hline Other $\ldots \ldots \ldots \ldots$ & 10.18 & 10.69 & 11.69 & 12.67 & 13.91 & 15.13 & 15.04 & 15.85 & 16.04 & 16.24 \\
\hline Multifamily residential & .73 & .80 & .96 & 1.07 & 1.13 & 1.21 & 1.29 & 1.29 & 1.26 & 1.43 \\
\hline Nonfarm nonresidential & 9.11 & 9.50 & 9.69 & 9.75 & 9.57 & 9.48 & 9.88 & 10.57 & 11.03 & 12.12 \\
\hline In foreign offices ........ & .03 & .05 & .04 & .02 & .03 & .02 & .02 & .02 & .02 & .02 \\
\hline Depository institutions & 1.05 & .93 & .80 & .43 & .40 & .35 & .48 & .57 & .02 & .44 \\
\hline Foreign governments. & .09 & .07 & .05 & .03 & .02 & .02 & .02 & .02 & .03 & .03 \\
\hline Agricultural production & .47 & .49 & .54 & .56 & .62 & .69 & .71 & .74 & .80 & .78 \\
\hline Other loans $\ldots \ldots \ldots \ldots \ldots$ & 3.16 & 2.81 & 2.47 & 2.16 & 2.01 & 1.80 & 1.69 & 1.50 & 1.32 & 1.27 \\
\hline Lease-financing receivables .... & .83 & .85 & .79 & .77 & .83 & .90 & 1.01 & .99 & .99 & .78 \\
\hline LESS: Unearned income on loans & -.50 & -.40 & -.30 & -.21 & -.15 & -.12 & -.10 & -.10 & -.09 & -.08 \\
\hline LEss: Loss reserves ${ }^{1} \ldots \ldots \ldots$ & -1.20 & -1.42 & -1.49 & -1.44 & -1.30 & -1.22 & -1.22 & -1.18 & -1.13 & -1.06 \\
\hline Securities ............. & 19.34 & 21.28 & 24.13 & 25.92 & 25.71 & 23.09 & 22.67 & 23.47 & 24.26 & 25.16 \\
\hline Investment account & 18.87 & 20.91 & 23.78 & 25.64 & 25.40 & 22.89 & 22.55 & 23.36 & 24.15 & 25.08 \\
\hline Debt .............. & 18.54 & 20.55 & 23.32 & 25.16 & 24.95 & 22.43 & 22.03 & 22.75 & 23.47 & 24.31 \\
\hline U.S. Treasury $\ldots \ldots \ldots \ldots$ & 5.44 & 6.16 & 7.75 & 8.64 & 8.26 & 6.49 & 5.61 & 4.95 & 3.92 & 2.53 \\
\hline U.S. government agency and & & & & & & & & & & \\
\hline corporation obligations $\ldots \ldots \ldots$ & 7.75 & 9.35 & 11.08 & 12.32 & 12.67 & 12.23 & 12.66 & 13.98 & 15.13 & 16.28 \\
\hline Government-backed mortgage pools & 3.83 & 4.51 & 4.74 & 4.97 & 5.57 & 5.42 & 5.68 & 6.23 & 6.46 & 6.71 \\
\hline Collateralized mortgage obligations . & 1.72 & 2.73 & 3.95 & 4.82 & 4.39 & 3.56 & 3.12 & 3.02 & 3.23 & 3.52 \\
\hline Other $\ldots \ldots \ldots \ldots \ldots \ldots \ldots$ & 2.19 & 2.11 & 2.39 & 2.53 & 2.71 & 3.25 & 3.85 & 4.73 & 5.44 & 6.06 \\
\hline 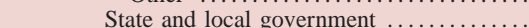 & 3.11 & 2.65 & 2.27 & 2.26 & 2.29 & 2.13 & 2.24 & 2.45 & 2.70 & 2.91 \\
\hline Private mortgage-backed securities & n.a. & 1.16 & 1.01 & .84 & .75 & .68 & .76 & .59 & .65 & 1.00 \\
\hline Other $\ldots \ldots \ldots \ldots \ldots \ldots \ldots \ldots$ & 2.25 & 1.23 & 1.21 & 1.10 & .99 & .89 & .77 & .78 & 1.06 & 1.59 \\
\hline Equity $\ldots . . . .$. & .32 & .37 & .46 & .48 & 44 & .47 & .52 & 61 & .69 & .77 \\
\hline Trading account $\ldots \ldots \ldots \ldots \ldots \ldots \ldots$ & .48 & .36 & .35 & .28 & .31 & .20 & .12 & .10 & .11 & .08 \\
\hline Gross federal funds sold and reverse RPs & 4.51 & 4.71 & 4.92 & 4.48 & 3.64 & 3.91 & 3.87 & 3.59 & 4.18 & 3.35 \\
\hline Interest-bearing balances at depositories .. & 1.90 & 1.89 & 1.47 & 1.20 & .98 & .93 & .96 & 1.03 & .83 & .75 \\
\hline 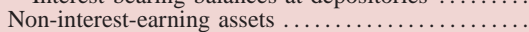 & 11.16 & 11.09 & 10.98 & 10.45 & 9.91 & 9.88 & 9.87 & 9.69 & 9.61 & 9.25 \\
\hline Revaluation gains on off-balance-sheet items $^{2}$ & n.a. & n.a. & n.a. & n.a. & .02 & .05 & .02 & $*$ & $*$ & .01 \\
\hline 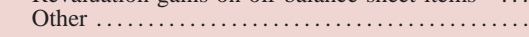 & 11.16 & 11.09 & 10.98 & 10.45 & 9.90 & 9.83 & 9.84 & 9.69 & 9.61 & 9.24 \\
\hline Liabilities...$\ldots \ldots \ldots \ldots$. & 93.07 & 92.89 & 92.47 & 91.85 & 91.62 & 91.36 & 91.06 & 90.79 & 90.55 & 90.90 \\
\hline Interest-bearing liabilities & 77.04 & 77.26 & 75.98 & 74.42 & 74.77 & 75.00 & 75.06 & 75.19 & 75.43 & 76.78 \\
\hline Deposits ............. & 65.05 & 66.35 & 65.65 & 63.05 & 60.38 & 59.69 & 59.99 & 61.51 & 62.41 & 61.97 \\
\hline In foreign offices & 1.65 & 1.76 & 1.56 & 1.43 & 1.69 & 1.71 & 1.33 & 1.23 & 1.31 & 1.20 \\
\hline In domestic offices ........ & 63.40 & 64.59 & 64.09 & 61.62 & 58.69 & 57.97 & 58.66 & 60.28 & 61.10 & 60.77 \\
\hline Other checkable deposits & 7.31 & 7.83 & 9.14 & 9.94 & 9.70 & 8.54 & 6.21 & 4.97 & 4.23 & 3.76 \\
\hline Savings (including MMDAs) $\ldots . .$. & 19.69 & 20.79 & 23.34 & 24.06 & 22.92 & 20.76 & 22.51 & 23.60 & 25.66 & 27.36 \\
\hline Small-denomination time deposits .. & 24.09 & 25.22 & 23.56 & 20.77 & 19.29 & 21.12 & 21.61 & 22.05 & 21.21 & 19.62 \\
\hline Large-denomination time deposits & 12.31 & 10.76 & 8.06 & 6.85 & 6.78 & 7.56 & 8.34 & 9.66 & 9.99 & 10.03 \\
\hline Gross federal funds purchased and RPs $\ldots$ & 8.43 & 7.46 & 7.17 & 7.43 & 8.45 & 8.31 & 8.19 & 7.08 & 6.16 & 6.91 \\
\hline Other $\ldots \ldots \ldots \ldots \ldots \ldots \ldots \ldots \ldots \ldots$ & 3.56 & 3.45 & 3.15 & 3.93 & 5.94 & 7.00 & 6.88 & 6.59 & 6.86 & 7.90 \\
\hline Non-interest-bearing liabilities $\ldots \ldots \ldots \ldots \ldots \ldots$ & 16.03 & 15.63 & 16.49 & 17.43 & 16.85 & 16.36 & 16.00 & 15.60 & 15.13 & 14.12 \\
\hline Demand deposits in domestic offices ............ & 14.07 & 13.56 & 14.39 & 15.07 & 14.58 & 14.07 & 13.84 & 13.16 & 11.91 & 10.20 \\
\hline Revaluation losses on off-balance-sheet items ${ }^{2}$ & n.a. & n.a. & n.a. & n.a. & .02 & .05 & .02 & .01 & .01 & .01 \\
\hline Other $\ldots \ldots \ldots \ldots \ldots \ldots \ldots \ldots \ldots \ldots \ldots \ldots \ldots$ & 1.96 & 2.07 & 2.10 & 2.36 & 2.25 & 2.24 & 2.14 & 2.44 & 3.22 & 3.91 \\
\hline Capital account & 6.93 & 7.11 & 7.53 & 8.15 & 8.38 & 8.64 & 8.94 & 9.21 & 9.45 & 9.10 \\
\hline Мемо & & & & & & & & & & \\
\hline Commercial real estate loans & n.a. & 14.63 & 13.91 & 13.37 & 13.05 & 13.20 & 13.84 & 14.79 & 15.38 & 17.28 \\
\hline Other real estate owned ..... & .52 & .77 & .80 & .57 & .28 & .17 & .13 & .11 & .09 & .08 \\
\hline Managed liabilities.......... & 26.00 & 23.48 & 20.00 & 19.69 & 22.89 & 24.61 & 24.78 & 24.63 & 24.46 & 26.31 \\
\hline $\begin{array}{l}\text { Average net consolidated assets } \\
\text { (billions of dollars) ....... }\end{array}$ & 937 & 962 & 968 & 977 & 1,032 & 1,092 & 1,076 & 967 & 935 & 972 \\
\hline
\end{tabular}




\section{A.2.-Continued}

D. Banks ranked 101 through 1,000 by assets

\begin{tabular}{|c|c|c|c|c|c|c|c|c|c|c|}
\hline Item & 1990 & 1991 & 1992 & 1993 & 1994 & 1995 & 1996 & 1997 & 1998 & 1999 \\
\hline & \multicolumn{10}{|c|}{ Effective interest rate (percent) ${ }^{3}$} \\
\hline \multicolumn{11}{|l|}{ Rates earned } \\
\hline Interest-earning assets . & 10.42 & 9.55 & 8.14 & 7.43 & 7.58 & 8.42 & 8.40 & 8.50 & 8.31 & 7.83 \\
\hline Taxable equivalent ... & 10.57 & 9.70 & 8.25 & 7.55 & 7.68 & 8.51 & 8.49 & 8.59 & 8.43 & 7.92 \\
\hline Loans and leases, gross $\ldots$ & 11.21 & 10.43 & 9.11 & 8.57 & 8.64 & 9.43 & 9.38 & 9.48 & 9.36 & 8.75 \\
\hline Net of loss provisions $\ldots$ & 9.48 & 8.72 & 7.83 & 7.76 & 8.11 & 8.76 & 8.59 & 8.60 & 8.60 & 8.13 \\
\hline Securities $\ldots \ldots \ldots \ldots \ldots \ldots$. & 8.52 & 8.11 & 6.88 & 5.78 & 5.69 & 6.23 & 6.31 & 6.42 & 6.22 & 6.02 \\
\hline Taxable equivalent & 9.00 & 8.54 & 7.19 & 6.10 & 5.93 & 6.49 & 6.59 & 6.69 & 6.57 & 6.29 \\
\hline Investment account $\ldots \ldots \ldots \ldots \ldots$ & 8.49 & 8.12 & 6.90 & 5.79 & 5.69 & 6.24 & 6.31 & 6.42 & 6.22 & 6.01 \\
\hline U.S. government and other debt & 8.76 & 8.30 & 6.95 & 5.76 & 5.68 & 6.28 & 6.40 & 6.55 & 6.35 & 6.16 \\
\hline State and local $\ldots \ldots \ldots \ldots \ldots \ldots$ & 7.33 & 7.25 & 6.83 & 6.30 & 5.92 & 5.80 & 5.50 & 5.36 & 5.15 & 4.98 \\
\hline Equity $\ldots \ldots \ldots$ & 6.94 & 6.02 & 5.08 & 4.95 & 5.30 & 6.05 & 6.30 & 6.35 & 6.34 & 5.97 \\
\hline Trading account $\ldots \ldots \ldots \ldots \ldots \ldots \ldots$ & 9.92 & 7.19 & 5.61 & 4.74 & 5.29 & 5.55 & 5.94 & 6.37 & 6.84 & 7.18 \\
\hline Gross federal funds sold and reverse RPs & 7.99 & 5.64 & 3.47 & 3.02 & 4.06 & 5.45 & 5.24 & 5.41 & 5.30 & 4.97 \\
\hline Interest-bearing balances at depositories . & 8.52 & 6.82 & 4.61 & 3.51 & 4.28 & 6.09 & 5.54 & 5.49 & 5.70 & 5.05 \\
\hline \multicolumn{11}{|l|}{ Rates paid } \\
\hline Interest-bearing liabilities . & 7.26 & 6.11 & 4.19 & 3.33 & 3.57 & 4.64 & 4.57 & 4.66 & 4.59 & 4.19 \\
\hline Interest-bearing deposits & 7.05 & 6.06 & 4.17 & 3.26 & 3.31 & 4.26 & 4.26 & 4.34 & 4.28 & 3.84 \\
\hline In foreign offices $\ldots .$. & 8.12 & 6.38 & 4.25 & 3.35 & 4.31 & 5.94 & 5.43 & 5.42 & 5.54 & 5.07 \\
\hline In domestic offices $\ldots \ldots \ldots$. & 7.02 & 6.05 & 4.17 & 3.25 & 3.28 & 4.21 & 4.23 & 4.32 & 4.25 & 3.82 \\
\hline Other checkable deposits & 4.75 & 4.28 & 2.67 & 2.02 & 1.87 & 2.02 & 1.96 & 2.17 & 2.15 & 1.98 \\
\hline Savings (including MMDAs) ...... & 5.98 & 5.14 & 3.33 & 2.58 & 2.64 & 3.24 & 3.11 & 3.08 & 2.96 & 2.65 \\
\hline Large-denomination time deposits ${ }^{4}$ & 8.04 & 6.64 & 4.76 & 3.90 & 4.23 & 5.62 & 5.47 & 5.56 & 5.50 & 5.17 \\
\hline Small-denomination time deposits 4 & 8.03 & 7.08 & 5.35 & 4.40 & 4.40 & 5.53 & 5.57 & 5.57 & 5.64 & 5.11 \\
\hline Gross federal funds purchased and RPs $\ldots \ldots$ & 7.86 & 5.62 & 3.46 & 2.95 & 4.12 & 5.61 & 5.16 & 5.21 & 5.13 & 4.82 \\
\hline \multirow[t]{2}{*}{ Other interest-bearing liabilities .............. } & 8.28 & 6.78 & 5.28 & 4.44 & 4.92 & 6.27 & 5.89 & 6.12 & 6.00 & 5.37 \\
\hline & \multicolumn{10}{|c|}{ Income and expense as a percentage of average net consolidated assets } \\
\hline Gross interest income. & 9.38 & 8.64 & 7.36 & 6.75 & 6.90 & 7.68 & 7.67 & 7.76 & 7.63 & 7.19 \\
\hline Taxable equivalent & 9.51 & 8.76 & 7.46 & 6.84 & 6.99 & 7.76 & 7.75 & 7.84 & 7.71 & 7.27 \\
\hline Loans...$\ldots \ldots \ldots$. & 7.21 & 6.52 & 5.46 & 5.07 & 5.26 & 5.98 & 5.99 & 6.01 & 5.85 & 5.48 \\
\hline Securities $\ldots \ldots \ldots \ldots \ldots \ldots \ldots \ldots \ldots \ldots$ & 1.60 & 1.70 & 1.64 & 1.49 & 1.45 & 1.43 & 1.42 & 1.50 & 1.50 & 1.51 \\
\hline Gross federal funds sold and reverse RPs & .36 & .28 & .17 & .14 & .14 & .21 & .20 & .19 & .22 & .17 \\
\hline Other $\ldots \ldots \ldots \ldots \ldots \ldots \ldots \ldots \ldots \ldots \ldots \ldots$ & .20 & .15 & .08 & .06 & .06 & .07 & .06 & .06 & .05 & .04 \\
\hline Gross interest expense & 5.54 & 4.68 & 3.16 & 2.46 & 2.65 & 3.46 & 3.40 & 3.47 & 3.44 & 3.20 \\
\hline Deposits $\ldots \ldots \ldots \ldots \ldots \ldots \ldots \ldots$ & 4.58 & 4.03 & 2.75 & 2.07 & 2.01 & 2.56 & 2.57 & 2.70 & 2.71 & 2.44 \\
\hline Gross federal funds purchased and RPs & .67 & .42 & .25 & .22 & .35 & .46 & .43 & .37 & .32 & .34 \\
\hline Other $\ldots \ldots \ldots \ldots \ldots \ldots \ldots \ldots \ldots \ldots \ldots \ldots$ & .29 & .23 & .17 & .17 & .29 & .44 & .40 & .40 & .41 & .42 \\
\hline Net interest income .... & 3.83 & 3.96 & 4.19 & 4.28 & 4.25 & 4.23 & 4.27 & 4.29 & 4.19 & 3.99 \\
\hline Taxable equivalent & 3.97 & 4.08 & 4.30 & 4.38 & 4.34 & 4.31 & 4.35 & 4.37 & 4.27 & 4.07 \\
\hline Loss provisioning ${ }^{5} \ldots$. & 1.12 & 1.07 & .77 & .47 & .33 & .43 & .50 & .56 & .48 & .39 \\
\hline Noninterest income $\ldots \ldots \ldots \ldots$ & 1.50 & 1.65 & 1.69 & 1.84 & 1.86 & 1.84 & 1.88 & 2.08 & 2.26 & 2.32 \\
\hline Service charges on deposits $\ldots$. & .37 & .40 & .44 & .45 & .42 & .42 & .42 & .40 & .39 & .38 \\
\hline Income from fiduciary activities ...... & .26 & .27 & .28 & .29 & .28 & .27 & .28 & .32 & .37 & .38 \\
\hline Trading income $\ldots \ldots \ldots \ldots \ldots \ldots \ldots$ & .02 & .04 & .02 & .03 & .02 & .03 & .02 & .01 & .02 & .02 \\
\hline Interest rate exposures $\ldots \ldots \ldots \ldots \ldots \ldots$ & n.a. & n.a. & n.a. & n.a. & n.a. & n.a. & .01 & .01 & .01 & .01 \\
\hline Foreign exchange exposures $\ldots \ldots \ldots \ldots$ & n.a. & n.a. & n.a. & n.a. & n.a. & n.a. & .01 & $*$ & $*$ & $*$ \\
\hline Equity, commodity, and other exposures .. & n.a. & n.a. & n.a. & n.a. & n.a. & n.a. & * & $*$ & $*$ & * \\
\hline 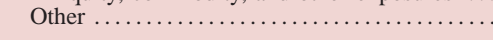 & .84 & .95 & .95 & 1.08 & 1.14 & 1.12 & 1.16 & 1.34 & 1.48 & 1.54 \\
\hline Noninterest expense $\ldots \ldots \ldots \ldots \ldots \ldots$ & 3.50 & 3.77 & 3.87 & 3.92 & 3.78 & 3.68 & 3.68 & 3.73 & 3.86 & 3.70 \\
\hline Salaries, wages, and employee benefits . & 1.47 & 1.48 & 1.51 & 1.51 & 1.49 & 1.44 & 1.44 & 1.51 & 1.57 & 1.56 \\
\hline Expenses of premises and fixed assets & .49 & .49 & .49 & .48 & .46 & .45 & .45 & .46 & .47 & .47 \\
\hline Other $\ldots \ldots \ldots \ldots \ldots \ldots \ldots \ldots \ldots \ldots$ & 1.55 & 1.80 & 1.87 & 1.93 & 1.83 & 1.79 & 1.80 & 1.76 & 1.83 & 1.68 \\
\hline Net noninterest expense $\ldots \ldots \ldots \ldots \ldots \ldots \ldots$ & 2.01 & 2.12 & 2.18 & 2.08 & 1.92 & 1.84 & 1.81 & 1.65 & 1.61 & 1.39 \\
\hline Realized gains on investment account securities & .01 & .09 & .10 & .06 & -.05 & -.01 & .02 & .02 & .04 & -.01 \\
\hline Income before taxes and extraordinary items ... & .72 & .86 & 1.35 & 1.78 & 1.96 & 1.96 & 1.98 & 2.10 & 2.15 & 2.21 \\
\hline 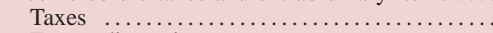 & .21 & .29 & .44 & .61 & .67 & .67 & .69 & .73 & .73 & .75 \\
\hline Extraordinary items $\ldots \ldots \ldots$ & $*$ & -.07 & $*$ & .04 & * & * & $*$ & $*$ & .06 & .01 \\
\hline Net income (return on assets) & .51 & .49 & .91 & 1.22 & 1.29 & 1.28 & 1.29 & 1.37 & 1.47 & 1.47 \\
\hline Cash dividends declared ... & .53 & .33 & .49 & .79 & .81 & .87 & 1.04 & 1.10 & 1.01 & 1.06 \\
\hline Retained income ....... & -.02 & .16 & .42 & .43 & .48 & .41 & .25 & .28 & .46 & .41 \\
\hline Memo: Return on equity & 7.37 & 6.93 & 12.13 & 14.93 & 15.40 & 14.82 & 14.45 & 14.93 & 15.56 & 16.19 \\
\hline
\end{tabular}

* In absolute value, less than 0.005 percent.

n.a. Not available. MMDA Money market deposit account. RP Repurchase agreement. CD Certificate of deposit.

1. Includes the allowance for loan and lease losses and the allocated transfer risk reserve.

2. Before 1994, the netted value of off-balance-sheet items appeared in "trading account securities"

if a gain and "other non-interest-bearing liabilities" if a loss.

3. When possible, based on the average of quarterly balance sheet data reported on schedule RC-K of the quarterly Call Reports.

3. Includes provisions for loan and lease losses and for allocated transfer risk.

4. Before 1997, data for large time open accounts are included in small-denomination time deposits.

5. Includes provisions for loan and lease losses and for allocated transfer risk. 
A.2. Portfolio composition, interest rates, and income and expense, all U.S. banks, 1990-99

E. Banks not ranked among the 1,000 largest by assets

\begin{tabular}{|c|c|c|c|c|c|c|c|c|c|c|}
\hline Item & 1990 & 1991 & 1992 & 1993 & 1994 & 1995 & 1996 & 1997 & 1998 & 1999 \\
\hline & \multicolumn{10}{|c|}{ Balance sheet items as a percentage of average net consolidated assets } \\
\hline Interest-earning assets & 91.06 & 91.25 & 91.39 & 91.65 & 91.72 & 91.70 & 91.64 & 91.65 & 91.89 & 91.83 \\
\hline Loans and leases, net $\ldots . .$. & 54.74 & 54.05 & 53.03 & 52.94 & 54.64 & 56.62 & 57.37 & 58.77 & 59.12 & 59.74 \\
\hline Commercial and industrial & 11.53 & 10.60 & 9.74 & 9.24 & 9.31 & 9.65 & 9.98 & 10.15 & 10.33 & 10.65 \\
\hline U.S. addressees . . . . . . . . & 11.49 & 10.56 & 9.69 & 9.20 & 9.26 & 9.59 & 9.90 & 10.07 & 10.25 & 10.56 \\
\hline Foreign addressees $\ldots$ & .04 & .04 & .04 & .04 & .05 & .06 & .07 & .08 & .08 & .08 \\
\hline Consumer $\ldots \ldots \ldots \ldots$ & 11.20 & 10.44 & 9.69 & 9.18 & 9.37 & 9.57 & 9.41 & 9.06 & 8.47 & 8.16 \\
\hline Credit card . . . . . . . . & 1.00 & 1.02 & 1.00 & .93 & .96 & 1.04 & 1.03 & .91 & .70 & .68 \\
\hline Installment and other & 10.20 & 9.42 & 8.69 & 8.25 & 8.41 & 8.53 & 8.38 & 8.15 & 7.77 & 7.48 \\
\hline Real estate...$\ldots \ldots \ldots$ & 28.35 & 29.34 & 30.15 & 31.09 & 32.19 & 33.54 & 34.10 & 35.51 & 36.04 & 36.79 \\
\hline In domestic offices $\ldots \ldots \ldots \ldots \ldots \ldots$ & 28.35 & 29.33 & 30.15 & 31.08 & 32.19 & 33.54 & 34.09 & 35.50 & 36.04 & 36.79 \\
\hline Construction and land development & 2.37 & 2.18 & 1.98 & 1.93 & 2.14 & 2.38 & 2.61 & 2.82 & 3.01 & 3.28 \\
\hline Farmland $\ldots \ldots \ldots \ldots \ldots \ldots \ldots \ldots$ & 1.86 & 1.93 & 2.06 & 2.20 & 2.34 & 2.48 & 2.55 & 2.68 & 2.83 & 2.94 \\
\hline One- to four-family residential . & 15.37 & 16.00 & 16.44 & 16.81 & 16.95 & 17.45 & 17.47 & 18.15 & 18.05 & 17.64 \\
\hline Home equity $\ldots \ldots \ldots \ldots \ldots$ & 1.16 & 1.29 & 1.34 & 1.27 & 1.21 & 1.20 & 1.19 & 1.24 & 1.21 & 1.17 \\
\hline Other $\ldots \ldots \ldots \ldots$ & 14.21 & 14.71 & 15.10 & 15.54 & 15.73 & 16.25 & 16.28 & 16.91 & 16.84 & 16.47 \\
\hline Multifamily residential & .66 & .71 & .77 & .84 & .93 & .95 & .92 & .95 & .93 & .98 \\
\hline Nonfarm nonresidential & 8.09 & 8.50 & 8.90 & 9.30 & 9.83 & 10.27 & 10.54 & 10.91 & 11.21 & 11.95 \\
\hline In foreign offices $\ldots \ldots \ldots$ & * & $*$ & $*$ & * & * & * & * & * & $*$ & $*$ \\
\hline Depository institutions . & .23 & .20 & .13 & .12 & .13 & .16 & .17 & .17 & .12 & .13 \\
\hline Foreign governments ... & .01 & .01 & .01 & .02 & .01 & * & $*$ & * & $*$ & .01 \\
\hline Agricultural production & 3.30 & 3.48 & 3.55 & 3.58 & 3.89 & 3.95 & 3.93 & 4.05 & 4.27 & 4.04 \\
\hline Other loans ............ & 1.41 & 1.24 & .99 & .87 & .81 & .76 & .72 & .70 & .69 & .70 \\
\hline Lease-financing receivables $\ldots . .$. & .18 & .17 & .17 & .18 & .20 & .22 & .23 & .25 & .25 & .27 \\
\hline LESS: Unearned income on loans . & -.58 & -.51 & -.43 & -.36 & -.31 & -.30 & -.27 & -.24 & -.20 & -.15 \\
\hline 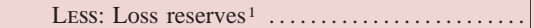 & -.89 & -.93 & -.96 & -.97 & -.95 & -.93 & -.90 & -.88 & -.86 & -.86 \\
\hline Securities ............ & 28.38 & 29.99 & 32.10 & 33.06 & 32.90 & 30.50 & 29.53 & 28.21 & 26.68 & 26.93 \\
\hline Investment account & 28.28 & 29.94 & 32.04 & 33.00 & 32.86 & 30.46 & 29.50 & 28.18 & 26.65 & 26.90 \\
\hline Debt ............ & 27.92 & 29.56 & 31.60 & 32.55 & 32.42 & 30.01 & 29.01 & 27.65 & 26.11 & 26.36 \\
\hline U.S. Treasury $\ldots \ldots \ldots \ldots \ldots$ & 8.77 & 9.24 & 10.25 & 10.48 & 10.81 & 9.19 & 7.85 & 6.70 & 5.05 & 3.33 \\
\hline U.S. government agency and & & & & & & & & & & \\
\hline corporation obligations $\ldots \ldots \ldots \ldots$ & 12.43 & 13.82 & 15.04 & 15.80 & 15.35 & 15.12 & 15.67 & 15.55 & 15.42 & 16.92 \\
\hline Government-backed mortgage pools . & 4.58 & 5.59 & 5.52 & 5.38 & 4.81 & 4.19 & 4.21 & 4.00 & 3.90 & 3.95 \\
\hline Collateralized mortgage obligations .... & .90 & 1.56 & 2.66 & 3.33 & 3.11 & 2.75 & 2.46 & 2.19 & 2.01 & 2.08 \\
\hline Other $\ldots \ldots \ldots \ldots \ldots \ldots \ldots$ & 6.93 & 6.68 & 6.85 & 7.09 & 7.43 & 8.18 & 9.00 & 9.37 & 9.51 & 10.89 \\
\hline State and local government ........ & 4.56 & 4.26 & 4.29 & 4.70 & 5.01 & 4.69 & 4.62 & 4.59 & 4.80 & 4.94 \\
\hline Private mortgage-backed securities .... & n.a. & .89 & .77 & .47 & .27 & .20 & .18 & .19 & .16 & .28 \\
\hline Other $\ldots \ldots \ldots \ldots \ldots \ldots \ldots$ & 2.15 & 1.34 & 1.26 & 1.10 & .98 & .81 & .68 & .61 & .68 & .89 \\
\hline Equity $(\ldots, \ldots, \ldots, \ldots, \ldots, \ldots, \ldots$ & .36 & .38 & .44 & .45 & .44 & .45 & .49 & .52 & .54 & .54 \\
\hline Trading account & .10 & .06 & .05 & .07 & .04 & .03 & .03 & .03 & .03 & .03 \\
\hline Gross federal funds sold and reverse RPs. . & 6.13 & 5.64 & 5.10 & 4.69 & 3.42 & 3.92 & 4.05 & 3.96 & 5.12 & 4.16 \\
\hline Interest-bearing balances at depositories ... & 1.81 & 1.57 & 1.16 & .97 & .77 & .67 & .69 & .71 & .96 & 1.00 \\
\hline Non-interest-earning assets $\ldots \ldots \ldots \ldots \ldots \ldots \ldots$ & 8.94 & 8.75 & 8.61 & 8.35 & 8.28 & 8.30 & 8.36 & 8.35 & 8.11 & 8.17 \\
\hline Revaluation gains on off-balance-sheet items ${ }^{2}$ & n.a. & n.a. & n.a. & n.a. & * & * & * & * & $*$ & $*$ \\
\hline 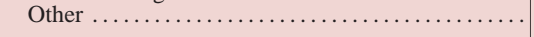 & 8.94 & 8.75 & 8.61 & 8.35 & 8.28 & 8.30 & 8.36 & 8.35 & 8.11 & 8.17 \\
\hline Liabilities .............. & 91.40 & 91.37 & 91.07 & 90.63 & 90.43 & 90.03 & 89.81 & 89.62 & 89.53 & 89.75 \\
\hline Interest-bearing liabilities . & 77.83 & 78.39 & 77.83 & 76.89 & 76.19 & 75.74 & 75.58 & 75.47 & 75.35 & 75.90 \\
\hline Deposits ............. & 75.79 & 76.40 & 75.75 & 74.53 & 73.14 & 72.68 & 72.47 & 71.99 & 71.76 & 71.34 \\
\hline In foreign offices.... & .07 & .08 & .07 & .08 & .09 & .11 & .10 & .09 & .07 & .08 \\
\hline In domestic offices $\ldots \ldots \ldots$ & 75.72 & 76.33 & 75.68 & 74.45 & 73.05 & 72.56 & 72.36 & 71.90 & 71.70 & 71.26 \\
\hline Other checkable deposits .... & 10.45 & 10.99 & 12.33 & 13.15 & 13.31 & 12.37 & 11.75 & 11.37 & 11.17 & 11.03 \\
\hline Savings (including MMDAs) & 18.73 & 19.35 & 22.10 & 23.55 & 23.23 & 20.40 & 19.56 & 18.98 & 19.01 & 19.71 \\
\hline Small-denomination time deposits $\ldots \ldots$. & 35.37 & 35.88 & 32.85 & 30.10 & 28.83 & 30.91 & 31.28 & 31.05 & 30.42 & 29.01 \\
\hline Large-denomination time deposits $\ldots \ldots$ & 11.17 & 10.11 & 8.40 & 7.65 & 7.68 & 8.88 & 9.77 & 10.49 & 11.10 & 11.51 \\
\hline Gross federal funds purchased and RPs ... & 1.36 & 1.31 & 1.36 & 1.44 & 1.89 & 1.78 & 1.70 & 1.68 & 1.50 & 1.82 \\
\hline Other $\ldots \ldots \ldots \ldots \ldots \ldots \ldots \ldots \ldots \ldots$ & .67 & .68 & .72 & .91 & 1.16 & 1.28 & 1.41 & 1.80 & 2.09 & 2.74 \\
\hline Non-interest-bearing liabilities . & 13.57 & 12.98 & 13.24 & 13.75 & 14.25 & 14.29 & 14.23 & 14.15 & 14.18 & 13.85 \\
\hline Demand deposits in domestic offices .......... & 12.37 & 11.84 & 12.23 & 12.82 & 13.34 & 13.22 & 13.13 & 13.09 & 13.08 & 12.80 \\
\hline Revaluation losses on off-balance-sheet items ${ }^{2}$. & n.a. & n.a. & n.a. & n.a. & * & * & * & * & * & $*$ \\
\hline 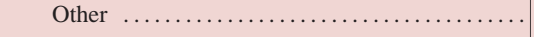 & 1.21 & 1.14 & 1.01 & .93 & .90 & 1.07 & 1.10 & 1.06 & 1.10 & 1.05 \\
\hline Capital account & 8.60 & 8.63 & 8.93 & 9.37 & 9.57 & 9.97 & 10.19 & 10.38 & 10.47 & 10.25 \\
\hline Мемо & & & & & & & & & & \\
\hline Commercial real estate loans & n.a. & 11.74 & 11.84 & 12.22 & 13.02 & 13.71 & 14.18 & 14.78 & 15.25 & 16.32 \\
\hline Other real estate owned ...... & .61 & .66 & .65 & .52 & .35 & .25 & .20 & .16 & .13 & .11 \\
\hline Managed liabilities $\ldots \ldots \ldots \ldots \ldots$ & 13.29 & 12.19 & 10.56 & 10.10 & 10.83 & 12.08 & 13.00 & 14.08 & 14.77 & 16.18 \\
\hline $\begin{array}{l}\text { Average net consolidated assets } \\
\text { (billions of dollars) } \ldots \ldots \ldots \ldots\end{array}$ & 681 & 694 & 697 & 688 & 679 & 666 & 661 & 648 & 644 & 654 \\
\hline
\end{tabular}




\section{A.2.-Continued}

E. Banks not ranked among the 1,000 largest by assets

\begin{tabular}{|c|c|c|c|c|c|c|c|c|c|c|}
\hline Item & 1990 & 1991 & 1992 & 1993 & 1994 & 1995 & 1996 & 1997 & 1998 & 1999 \\
\hline & \multicolumn{10}{|c|}{ Effective interest rate (percent) ${ }^{3}$} \\
\hline \multicolumn{11}{|l|}{ Rates earned } \\
\hline Interest-earning assets . & 10.31 & 9.64 & 8.43 & 7.62 & 7.57 & 8.41 & 8.35 & 8.50 & 8.33 & 8.04 \\
\hline Taxable equivalent ... & 10.52 & 9.82 & 8.59 & 7.78 & 7.72 & 8.56 & 8.49 & 8.63 & 8.49 & 8.18 \\
\hline Loans and leases, gross $\ldots$ & 11.60 & 11.02 & 9.83 & 9.14 & 9.00 & 9.85 & 9.74 & 9.81 & 9.70 & 9.29 \\
\hline Net of loss provisions & 10.65 & 10.08 & 9.05 & 8.63 & 8.65 & 9.42 & 9.31 & 9.36 & 9.22 & 8.80 \\
\hline Securities $\ldots \ldots \ldots \ldots \ldots \ldots$ & 8.42 & 8.04 & 6.99 & 5.92 & 5.61 & 6.09 & 6.10 & 6.25 & 5.98 & 5.86 \\
\hline Taxable equivalent & 8.99 & 8.53 & 7.40 & 6.33 & 5.99 & 6.49 & 6.52 & 6.65 & 6.47 & 6.29 \\
\hline Investment account $\ldots \ldots \ldots \ldots \ldots$ & 8.41 & 8.04 & 6.99 & 5.92 & 5.61 & 6.09 & 6.10 & 6.25 & 5.98 & 5.86 \\
\hline U.S. government and other debt & 8.59 & 8.20 & 7.06 & 5.91 & 5.59 & 6.17 & 6.23 & 6.43 & 6.16 & 6.04 \\
\hline State and local $\ldots \ldots \ldots \ldots \ldots \ldots$ & 7.46 & 7.17 & 6.70 & 6.09 & 5.69 & 5.64 & 5.44 & 5.32 & 5.15 & 5.03 \\
\hline Equity $\ldots \ldots \ldots$ & 8.30 & 7.14 & 5.64 & 5.16 & 5.52 & 6.26 & 6.06 & 6.40 & 6.11 & 6.15 \\
\hline Trading account $\ldots \ldots \ldots \ldots \ldots \ldots \ldots$ & 12.13 & 8.41 & 7.14 & 4.83 & 6.03 & 6.12 & 6.48 & 6.60 & 4.61 & 4.04 \\
\hline Gross federal funds sold and reverse RPs & 8.12 & 5.66 & 3.51 & 2.95 & 4.08 & 5.95 & 5.39 & 5.51 & 5.36 & 4.97 \\
\hline Interest-bearing balances at depositories . & 8.55 & 7.35 & 5.59 & 4.53 & 4.64 & 5.91 & 6.10 & 5.70 & 5.66 & 5.69 \\
\hline \multicolumn{11}{|l|}{ Rates paid } \\
\hline Interest-bearing liabilities . & 7.02 & 6.17 & 4.44 & 3.54 & 3.49 & 4.47 & 4.49 & 4.61 & 4.60 & 4.28 \\
\hline Interest-bearing deposits & 6.96 & 6.15 & 4.44 & 3.53 & 3.44 & 4.39 & 4.44 & 4.54 & 4.53 & 4.22 \\
\hline In foreign offices $\ldots .$. & 7.57 & 5.95 & 3.97 & 2.91 & 3.92 & 5.73 & 11.43 & 4.77 & 5.08 & 4.34 \\
\hline In domestic offices $\ldots \ldots \ldots$. & 6.96 & 6.15 & 4.44 & 3.53 & 3.44 & 4.39 & 4.43 & 4.54 & 4.53 & 4.22 \\
\hline Other checkable deposits & 5.02 & 4.61 & 3.14 & 2.42 & 2.29 & 2.50 & 2.41 & 2.46 & 2.45 & 2.28 \\
\hline Savings (including MMDAs) ...... & 5.73 & 5.18 & 3.62 & 2.91 & 2.83 & 3.32 & 3.24 & 3.37 & 3.39 & 3.21 \\
\hline Large-denomination time deposits ${ }^{4}$ & 7.92 & 6.72 & 4.90 & 3.96 & 4.12 & 5.55 & 5.49 & 5.53 & 5.54 & 5.22 \\
\hline Small-denomination time deposits 4 & 7.88 & 6.98 & 5.36 & 4.39 & 4.28 & 5.51 & 5.59 & 5.67 & 5.64 & 5.25 \\
\hline Gross federal funds purchased and RPs $\ldots \ldots$ & 8.03 & 5.72 & 3.74 & 3.17 & 4.12 & 5.62 & 5.10 & 5.23 & 5.05 & 4.73 \\
\hline \multirow[t]{2}{*}{ Other interest-bearing liabilities .............. } & 7.84 & 7.06 & 5.01 & 4.64 & 4.98 & 6.87 & 5.84 & 6.15 & 6.44 & 5.52 \\
\hline & \multicolumn{10}{|c|}{ Income and expense as a percentage of average net consolidated assets } \\
\hline Gross interest income. & 9.51 & 8.91 & 7.79 & 7.05 & 7.01 & 7.80 & 7.75 & 7.89 & 7.74 & 7.45 \\
\hline Taxable equivalent & 9.68 & 9.06 & 7.94 & 7.19 & 7.15 & 7.93 & 7.87 & 8.01 & 7.86 & 7.57 \\
\hline Loans...$\ldots \ldots \ldots$. & 6.44 & 6.04 & 5.30 & 4.91 & 4.98 & 5.66 & 5.67 & 5.85 & 5.80 & 5.59 \\
\hline Securities $\ldots \ldots \ldots \ldots \ldots \ldots \ldots \ldots \ldots \ldots$ & 2.38 & 2.41 & 2.24 & 1.95 & 1.84 & 1.86 & 1.80 & 1.76 & 1.59 & 1.58 \\
\hline Gross federal funds sold and reverse RPs & .53 & .34 & .18 & .14 & .15 & .25 & .24 & .24 & .29 & .22 \\
\hline Other $\ldots \ldots \ldots \ldots \ldots \ldots \ldots \ldots \ldots \ldots \ldots \ldots$ & .17 & .12 & .07 & .05 & .04 & .04 & .04 & .04 & .05 & .06 \\
\hline Gross interest expense & 5.44 & 4.82 & 3.45 & 2.72 & 2.65 & 3.38 & 3.38 & 3.47 & 3.46 & 3.24 \\
\hline Deposits $\ldots \ldots \ldots \ldots \ldots \ldots \ldots \ldots$ & 5.28 & 4.70 & 3.36 & 2.63 & 2.52 & 3.19 & 3.22 & 3.28 & 3.25 & 3.01 \\
\hline Gross federal funds purchased and RPs & .11 & .07 & .05 & .04 & .07 & .10 & .08 & .08 & .07 & .08 \\
\hline Other $\ldots \ldots \ldots \ldots \ldots \ldots \ldots \ldots \ldots \ldots \ldots \ldots$ & .05 & .05 & .04 & .04 & .06 & .09 & .08 & .11 & .13 & .15 \\
\hline Net interest income .... & 4.07 & 4.09 & 4.34 & 4.33 & 4.36 & 4.42 & 4.37 & 4.41 & 4.28 & 4.21 \\
\hline Taxable equivalent & 4.24 & 4.24 & 4.49 & 4.48 & 4.50 & 4.55 & 4.49 & 4.54 & 4.40 & 4.33 \\
\hline Loss provisioning ${ }^{5} \ldots$. & .53 & .51 & .42 & .27 & .19 & .25 & .25 & .27 & .29 & .30 \\
\hline Noninterest income...$\ldots \ldots$ & 1.01 & 1.07 & 1.16 & 1.25 & 1.30 & 1.38 & 1.42 & 1.44 & 1.52 & 1.43 \\
\hline Service charges on deposits $\ldots$. & .42 & .44 & .45 & .45 & .44 & .44 & .44 & .44 & .42 & .42 \\
\hline Income from fiduciary activities ...... & .14 & .14 & .16 & .16 & .17 & .22 & .20 & .20 & .23 & .26 \\
\hline Trading income $\ldots \ldots \ldots \ldots \ldots \ldots \ldots$ & .01 & .01 & .01 & .01 & $*$ & .01 & $*$ & $*$ & $*$ & $*$ \\
\hline Interest rate exposures $\ldots \ldots \ldots \ldots \ldots \ldots$ & n.a. & n.a. & n.a. & n.a. & n.a. & n.a. & $*$ & $*$ & * & * \\
\hline Foreign exchange exposures $\ldots \ldots \ldots \ldots$ & n.a. & n.a. & n.a. & n.a. & n.a. & n.a. & $*$ & $*$ & $*$ & $*$ \\
\hline Equity, commodity, and other exposures .. & n.a. & n.a. & n.a. & n.a. & n.a. & n.a. & $*$ & $*$ & $*$ & * \\
\hline 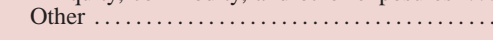 & .44 & .49 & .55 & .64 & .69 & .71 & .78 & .79 & .86 & .75 \\
\hline Noninterest expense $\ldots \ldots \ldots \ldots \ldots \ldots$ & 3.49 & 3.59 & 3.67 & 3.74 & 3.78 & 3.81 & 3.70 & 3.70 & 3.74 & 3.71 \\
\hline Salaries, wages, and employee benefits & 1.64 & 1.64 & 1.69 & 1.72 & 1.75 & 1.80 & 1.77 & 1.80 & 1.82 & 1.81 \\
\hline Expenses of premises and fixed assets & .49 & .49 & .49 & .48 & .49 & .50 & .49 & .49 & .49 & .49 \\
\hline Other $\ldots \ldots \ldots \ldots \ldots \ldots \ldots \ldots \ldots \ldots$ & 1.36 & 1.46 & 1.49 & 1.53 & 1.55 & 1.51 & 1.44 & 1.41 & 1.43 & 1.41 \\
\hline Net noninterest expense $\quad \ldots \ldots \ldots \ldots \ldots \ldots \ldots$ & 2.48 & 2.52 & 2.51 & 2.48 & 2.48 & 2.43 & 2.28 & 2.27 & 2.22 & 2.28 \\
\hline Realized gains on investment account securities & $*$ & .06 & .09 & .07 & -.03 & $*$ & .01 & .01 & .02 & $*$ \\
\hline Income before taxes and extraordinary items ... & 1.06 & 1.11 & 1.50 & 1.64 & 1.66 & 1.75 & 1.85 & 1.89 & 1.79 & 1.63 \\
\hline 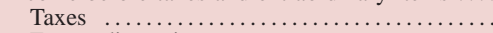 & .34 & .35 & .47 & .51 & .51 & .55 & .59 & .59 & .53 & .47 \\
\hline Extraordinary items $\ldots \ldots \ldots$ & .02 & .19 & .02 & .05 & $*$ & $*$ & $*$ & $*$ & $*$ & $*$ \\
\hline Net income (return on assets) & .74 & .95 & 1.04 & 1.19 & 1.15 & 1.20 & 1.26 & 1.30 & 1.26 & 1.17 \\
\hline Cash dividends declared ... & .49 & .89 & .50 & .56 & .57 & .62 & .64 & .73 & .83 & .67 \\
\hline Retained income ....... & .25 & .06 & .54 & .63 & .58 & .58 & .62 & .57 & .43 & .49 \\
\hline Memo: Return on equity & 8.61 & 11.05 & 11.64 & 12.65 & 12.05 & 12.05 & 12.33 & 12.54 & 12.01 & 11.39 \\
\hline
\end{tabular}

* In absolute value, less than 0.005 percent.

n.a. Not available. MMDA Money market deposit account. RP Repurchase agreement. CD Certificate of deposit.

1. Includes the allowance for loan and lease losses and the allocated transfer risk reserve.

2. Before 1994, the netted value of off-balance-sheet items appeared in "trading account securities"

if a gain and "other non-interest-bearing liabilities" if a loss.

3. When possible, based on the average of quarterly balance sheet data reported on schedule RC-K of the quarterly Call Reports.

4. Before 1997, data for large time open accounts are included in small-denomination time deposits.

5. Includes provisions for loan and lease losses and for allocated transfer risk. 